Prepared in cooperation with the San Diego Association of Governments

\title{
Population Genomic Surveys for Six Rare Plant Species in San Diego County, California
}
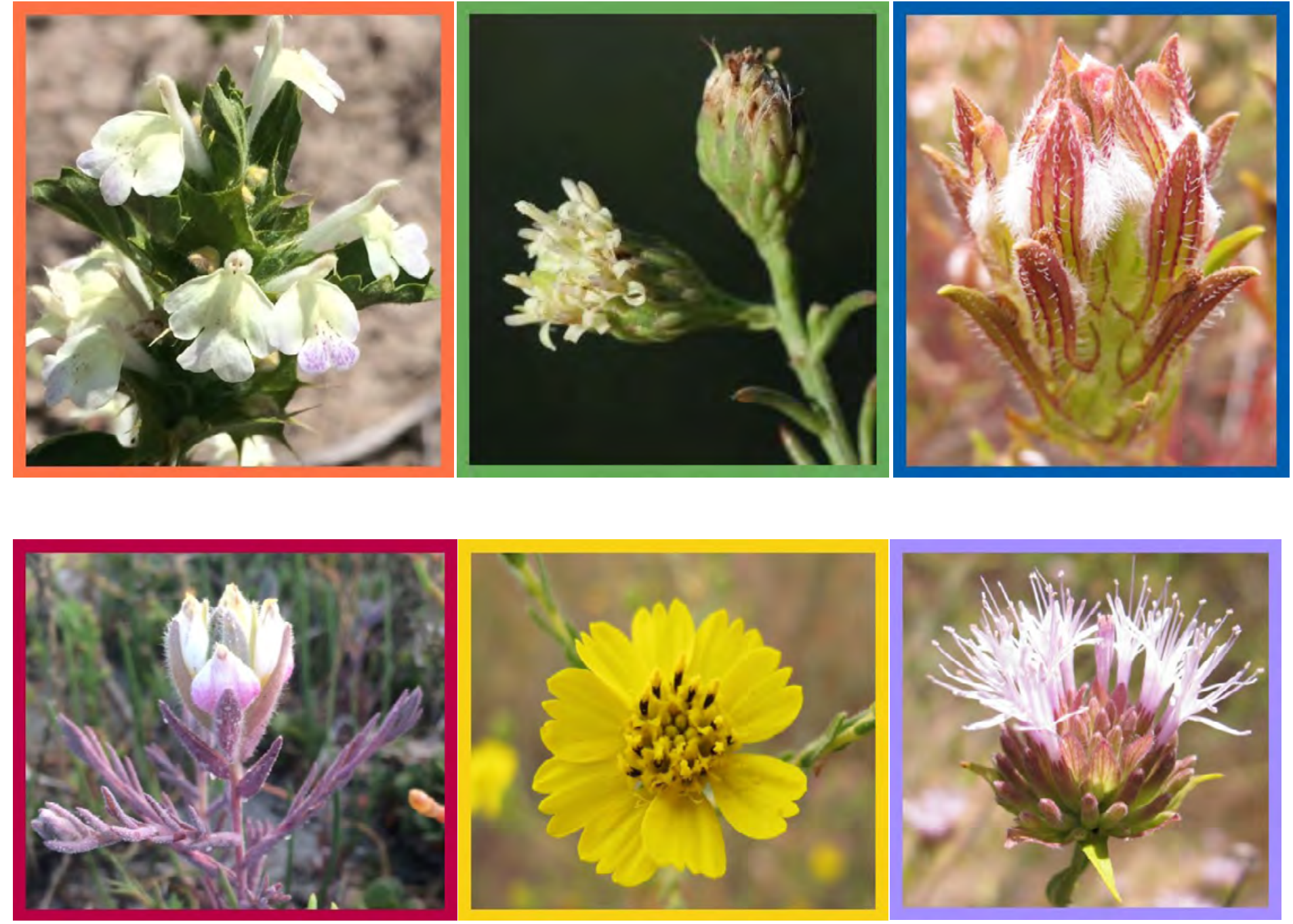

Open-File Report 2018-1175

U.S. Department of the Interior

U.S. Geological Survey 


\section{Cover photographs:}

Top Left: Acanthomintha ilicifolia (San Diego thornmint). Photograph by Margie Mulligan, 2016-17, San Diego County, California. Top Middle: Baccharis vanessae (Encinitas baccharis). Photograph by Jon Rebman, 2016-17, San Diego County, California.

Top Right: Dicranostegia orcuttiana (Orcutt's bird's-beak). Photograph by Margie Mulligan, 2016-17, San Diego County, California.

Bottom Left: Chloropyron maritimum ssp. maritimum (salt marsh bird's-beak). Photograph by Margie Mulligan, 2016-17, San Diego County, California.

Bottom Middle: Deinandra conjugens (Otay tarplant). Photograph by Margie Mulligan, 2016-17, San Diego County, California.

Bottom Right: Monardella viminea (willowy monardella). Photograph by Margie Mulligan, 2016-17, San Diego County, California.

Back: Field of Chloropyron maritimum ssp. maritimus (salt marsh bird's-beak) at Dog Beach in Ocean Beach. Photograph by E.R. Milano, July 21, 2017, San Deigo, California. 


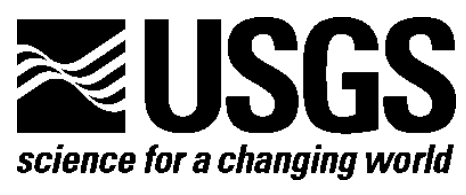

Prepared in cooperation with the San Diego Association of Governments

\section{Population Genomic Surveys of Six Rare Plant Species in San Diego County, California}

By Elizabeth R. Milano and Amy G. Vandergast

Open-File Report 2018-1175

U.S. Department of the Interior

U.S. Geological Survey 


\title{
U.S. Department of the Interior \\ RYAN K. ZINKE, Secretary
}

\section{U.S. Geological Survey James F. Reilly II, Director}

U.S. Geological Survey, Reston, Virginia: 2018

\begin{abstract}
For more information on the USGS-the Federal source for science about the Earth, its natural and living resources, natural hazards, and the environment-visit https://www.usgs.gov/ or call 1-888-ASK-USGS (1-888-275-8747).
\end{abstract}

For an overview of USGS information products, including maps, imagery, and publications, visit https://store.usgs.gov/.

Any use of trade, firm, or product names is for descriptive purposes only and does not imply endorsement by the U.S. Government.

Although this information product, for the most part, is in the public domain, it also may contain copyrighted materials as noted in the text. Permission to reproduce copyrighted items must be secured from the copyright owner.

Suggested citation:

Milano, E.R., and Vandergast, A.G., 2018, Population genomic surveys for six rare plant species in San Diego County, California: U.S. Geological Survey Open-File Report 2018-1175, 60 p., https://doi.org/10.3133/ofr20181175.

ISSN 2331-1258 (online) 


\section{Acknowledgments}

This research used resources provided by the Core Science Analytics, Synthesis, \& Libraries (CSASL) Advanced Research Computing (ARC) group at the U.S. Geological Survey (USGS). We acknowledge support from the San Diego Association of Governments and the USGS Ecosystems Mission Area and Western Ecological Research Center. This report is part of the rare plant monitoring effort by the San Diego Management and Monitoring Program and relied on expertise and field collections by J. Rebman and M.Mulligan with the San Diego Natural History Museum. We acknowledge K. Preston for valuable comments and workshop support; workshop attendees S. Anderson, L. Defalco, D. Elam, N. Fraga, P. Gordon-Reedy, C. Lieberman, J. Maschinski, K. McEachern, M. Neel, M. Osborne, K. Rice, and M. Spiegelberg; and R. Massatti and D. Shryock for providing valuable comments during the review process. 


\section{Contents}

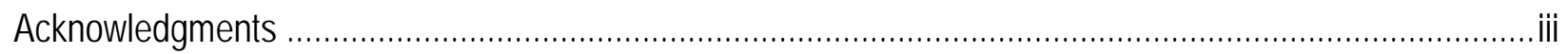

Abstract ……

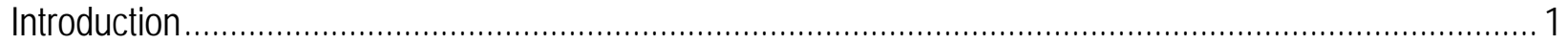

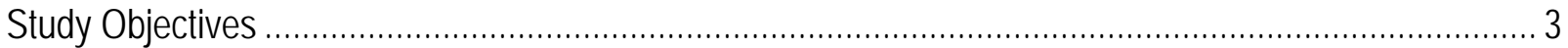

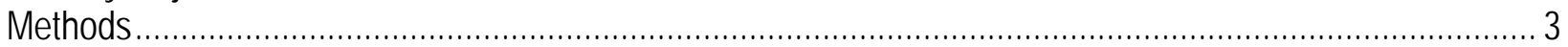

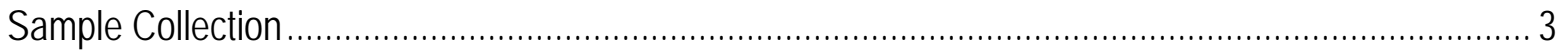

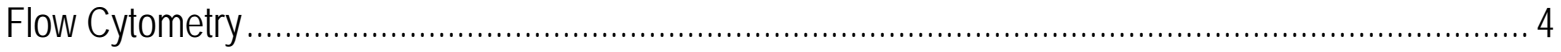

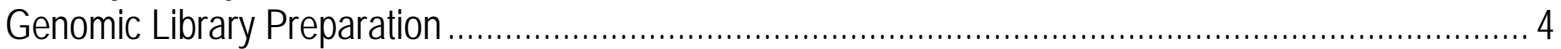

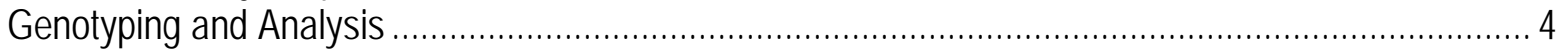

Management Ranking and Panel Discussion ............................................................................ 5

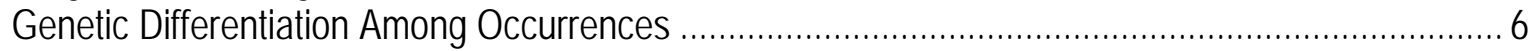

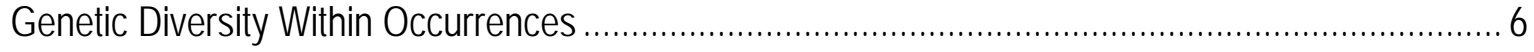

Inbreeding and Relatedness Within Occurrences................................................................. 6

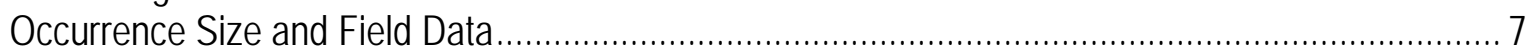

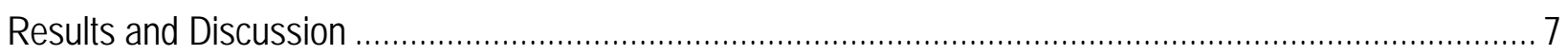

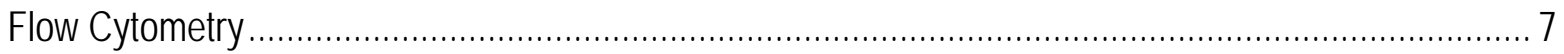

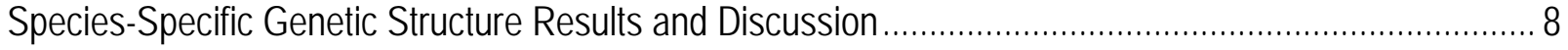

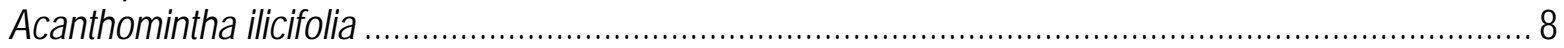

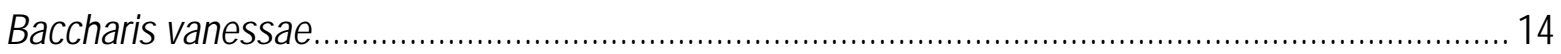

Chloropyron maritimum ssp. maritimum ............................................................................ 19

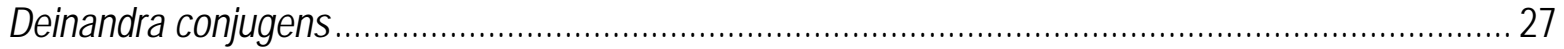

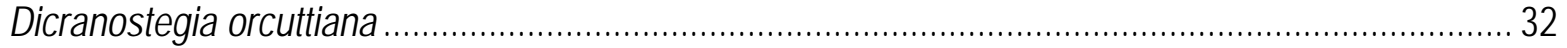

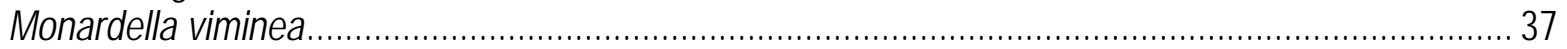

Management Rankings and Compatible Management Strategies.................................................... 42

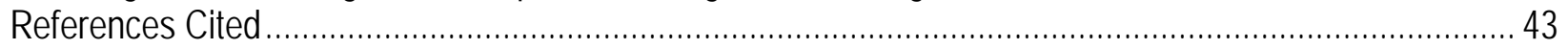

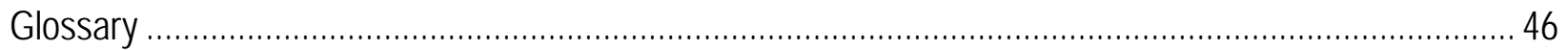

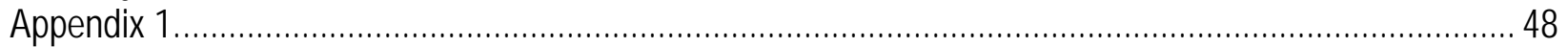

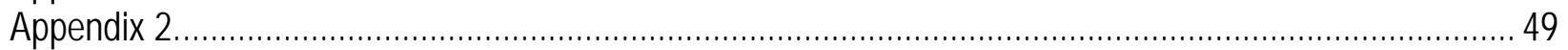

\section{Figures}

Figure 1. Map of sampled Acanthomintha ilicifolia occurrences..........................................................

Figure 2. Genetic diversity statistics for Acanthomintha ilicifolia reported as mean values and standard errors for each occurrence. Note the scale is unique to each dataset and should be considered before comparing across plots.

Figure 3. Pairwise $F_{S T}$ heatmap for Acanthomintha ilicifolia occurrences. Light color shading represents low genetic differentiation, and dark color shading represents high genetic differentiation; values provided in red. Note color scale is unique to each dataset and should not be compared across species.

Figure 4. Principal component (PC) plot for Acanthomintha ilicifolia occurrences with PC1 on the horizontal axis and PC2 on the vertical axis. Each point represents an individual sample, and each color and solid ellipse represents an occurrence. Grey hashed ellipses identify occurrences in specific geographic regions. Inset scree plot shows relative values of retained PCs, dimensional grid scale indicated in the upper right corner of main plot. 
Figure 5. Maximum likelihood membership probability of Acanthomintha ilicifolia where color represents probability of belonging to one of $\mathrm{K}=5$ genetic clusters. $A$, averaged by occurrence on map, and $B$, ordered north to south, where each bar represents an individual.

Figure 6. Map of sampled Baccharis vanessae occurrences.

Figure 7. Genetic diversity statistics for Baccharis vanessae reported as mean values and standard errors for each occurrence. Note the scale is unique to each dataset and should be considered before comparing across plots.

Figure 8. Pairwise $F_{S T}$ heatmap for Baccharis vanessae occurrences. Light color shading represents low genetic differentiation, and dark color shading represents high genetic differentiation; values provided in red. Note color scale is unique to each dataset and should not be compared across species.

Figure 9. Principal component (PC) plot for Baccharis vanessae occurrences with PC1 on the horizontal axis and PC2 on the vertical axis. Each point represents an individual sample, and each color and ellipse represents an occurrence. Inset scree plot shows relative values of retained PCs, dimensional grid scale indicated in the upper right corner of main plot. 18

Figure 10. Map of sampled San Diego Chloropyron maritimum ssp. maritimum occurrences.................... 20

Figure 11. Map of sampled regional Chloropyron maritimum ssp. maritimum occurrences........................ 21 Figure 12. Genetic diversity statistics for Chloropyron maritimum ssp. maritimum reported as mean values and standard errors for each occurrence. Note the scale is unique to each dataset and should be considered before comparing across plots.

Figure 13. Pairwise Fst heatmap for Chloropyron maritimum ssp. maritimum occurrences. Light color shading represents low genetic differentiation, and dark color shading represents high genetic differentiation; values provided in red. Note color scale is unique to each dataset and should not be compared across species.

Figure 14. Principal component (PC) plot for San Diego Chloropyron maritimum ssp. maritimum occurrences with PC1 on the horizontal axis and PC2 on the vertical axis. Each point represents an individual sample, and each color and ellipse represents an occurrence. Inset scree plot shows relative values of retained PCs, dimensional grid scale indicated in the upper right corner of main plot. Figure 15. Principal component (PC) plot for regional Chloropyron maritimum ssp. maritimum occurrences with PC1 on the horizontal axis and PC2 on the vertical axis. Each point represents an individual sample, and each color and solid ellipse represents an occurrence. Grey hashed ellipse identifies San Diego occurrences. Inset scree plot shows relative values of retained PCs, dimensional grid scale indicated in the upper right corner of main plot.

Figure 16. Maximum likelihood membership probability of regional Chloropyron maritimum ssp. maritimum where color represents probability of belonging to one of $\mathrm{K}=5$ genetic clusters. $A$, averaged by occurrence on map, and $B$, ordered north to south, where each bar represents an individual. ...................................... 26

Figure 17. Map of sampled Deinandra conjugens occurrences........................................................ 28 Figure 18. Genetic diversity statistics for Deinandra conjugens reported as mean values and standard errors for each occurrence. Note the scale is unique to each dataset and should be considered before comparing across plots.

Figure 19. Pairwise Fst heatmap for Deinandra conjugens occurrences. Light color shading represents low genetic differentiation, and dark color shading represents high genetic differentiation; values provided in red. Note color scale is unique to each dataset and should not be compared across species. ................... 30 Figure 20. Principal component (PC) plot for Deinandra conjugens occurrences with PC1 on the horizontal axis and PC2 on the vertical axis. Each point represents an individual sample, and each color and ellipse represents an occurrence. Inset scree plot shows relative values of retained PCs, dimensional grid scale indicated in the upper right corner of main plot. 31 Figure 21. Map of sampled Dicranostegia orcuttiana occurrences. ....................................................... 33 
Figure 22. Genetic diversity statistics for Dicranostegia orcuttiana reported as mean values and standard errors for each occurrence. Note the scale is unique to each dataset and should be considered before comparing across plots

Figure 23. Pairwise $F_{S T}$ heatmap for Dicranostegia orcuttiana occurrences. Light color shading represents low genetic differentiation, and dark color shading represents high genetic differentiation; values provided in red. Note color scale is unique to each dataset and should not be compared across species. 35

Figure 24. Principal component (PC) plot for Dicranostegia orcuttiana occurrences with PC1 on the horizontal axis and PC2 on the vertical axis. Each point represents an individual sample, and each color and ellipse represents an occurrence. Inset scree plot shows relative values of retained PCs, dimensional

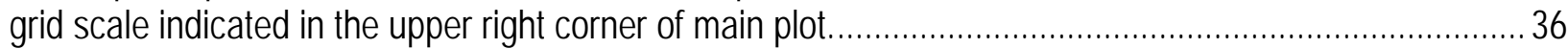
Figure 25. Map of sampled Monardella viminea occurrences............................................................. 38 Figure 26. Genetic diversity statistics for Monardella viminea reported as mean values and standard errors for each occurrence. Note the scale is unique to each dataset and should be considered before comparing across plots.

Figure 27. Pairwise $F_{S T}$ heatmap for Monardella viminea occurrences. Light color shading represents low genetic differentiation, and dark color shading represents high genetic differentiation; values provided in red. Note color scale is unique to each dataset and should not be compared across species.

Figure 28. Principal component (PC) plot for Monardella viminea occurrences with PC1 on the horizontal axis and PC2 on the vertical axis. Each point represents an individual sample, and each color and ellipse represents an occurrence. Inset scree plot shows relative values of retained PCs, dimensional grid scale indicated in the upper right corner of main plot.

Figure 1-1. Example histogram output from flow cytometry analysis; RN1 indicates peak position of internal standard, and RN2 indicates peak position of sample.

\section{Tables}

Table 1. Mean and standard deviation of flow cytometry peak ratios by species. .....................................

Table 2-1. Acanthomintha ilicifolia occurrence locations and summary statistics..................................... 49

Table 2-2. Baccharis vanessae occurrence locations and summary statistics.......................................50

Table 2-3. Chloropyron maritimum ssp. Maritimum occurrence locations and summary statistics............. 51

Table 2-4. Deinandra conjugens occurrence locations and summary statistics......................................52

Table 2-5. Dicranostegia orcuttiana occurrence locations and summary statistics...................................5 53

Table 2-6. Monardella viminea occurrence locations and summary statistics. .........................................54

Table 2-7. Summary of management ranking decision, compatible potential management options, and additional needed information by species. 


\section{Conversion Factors}

International System of Units to Inch/Pound

\begin{tabular}{lll}
\hline & Multiply & By \\
\hline & Mass & To obtain \\
\hline nanogram (ng) & $3.527 \times 10^{-11}$ ounce, avoirdupois (oz) \\
picogram (pg) & $3.527 \times 10^{-14}$ ounce, avoirdupois (oz) \\
\hline
\end{tabular}

\section{Datum}

Vertical coordinate information is referenced to the North American Vertical Datum of 1988 (NAVD 88). Horizontal coordinate information is referenced to the North American Datum of 1983 (NAD 83).

\section{Abbreviations}

$\begin{array}{ll}\text { AIC } & \text { Akaike information criterion } \\ \text { bp } & \text { base pair } \\ \text { BIC } & \text { Bayesian information criterion } \\ \text { CBI } & \text { Conservation Biology Institute } \\ \text { CPEN } & \text { Marine Corps Base Camp Pendleton } \\ \text { ddRAD } & \text { double-digest restriction-site associated DNA sequencing } \\ \text { DNA } & \text { deoxyribonucleic acid } \\ \text { IBD } & \text { isolation by distance } \\ \text { IMG } & \text { inspect and manage protocol } \\ \text { MCAS } & \text { Marine Corps Air Station } \\ \text { MSP } & \text { Management Strategic Plan } \\ \text { MPA } & \text { Management Plan Area } \\ \text { PCA } & \text { principal component analysis } \\ \text { PCR } & \text { polymerase chain reaction } \\ \text { qPCR } & \text { quantitative polymerase chain reaction } \\ \text { RSABG } & \text { Rancho Santa Ana Botanical Garden } \\ \text { SE } & \text { standard error } \\ \text { SNP } & \text { single nucleotide polymorphism } \\ \text { USDA } & \text { U.S. Department of Agriculture } \\ \text { USFWS } & \text { U.S. Fish and Wildlife Service } \\ \text { USGS } & \text { U.S. Geological Survey }\end{array}$




\title{
Population Genomic Surveys for Six Rare Plant Species in San Diego County, California
}

\author{
By Elizabeth R. Milano and Amy G. Vandergast
}

\begin{abstract}
San Diego County is a hotspot of biodiversity, situated at the intersection of the Baja peninsula, the California floristic province, and the desert southwest. This hotspot is characterized by a high number of rare and endemic species, which persist alongside a major urban epicenter. San Diego County has implemented a strategic management plan that identifies species, based on low numbers of occurrences or high level of threat, for which management practices are recommended. In creating a management plan for rare species, it is important to strike a balance between preserving locally adapted traits and maintaining genetic diversity, as species' ranges fluctuate in response to a changing climate and habitat fragmentation. This project, in partnership with the San Diego Natural History Museum, aims to provide a reference point for the current status of genetic diversity of rare plant species that will inform future preservation and restoration efforts. We focused on six threatened or endangered plant species: Acanthomintha ilicifolia, Baccharis vanessae, Chloropyron maritimum ssp. maritimum, Deinandra conjugens, Dicranostegia orcuttiana, and Monardella viminea. For each species, botanists from the San Diego Natural History Museum visited all known occurrences in San Diego County and collected leaf tissue for genetic and cytological analysis. We then developed a panel of genetic markers to estimate genetic diversity and population structure. This population genetic survey provided insight into the amount of genetic differentiation across each species' range, identified isolated occurrences potentially subject to inbreeding or genetic bottlenecks, and identified areas that are rich sources of allelic diversity. Finally, we convened a panel of experts to review results and compatible management options for each species. A summary of the management workshop is included in this report. Overall, we found low genetic differentiation among occurrences across the San Diego region for all species, with the exception of A. ilicifolia. Relative inbreeding was low and consistent across sites, and genetic diversity across sites was variable, with noted exceptions. These findings allow for a wide array of management options that are compatible with panmictic population structure in five of the six surveyed species.
\end{abstract}

\section{Introduction}

The Management Strategic Plan (MSP) for western San Diego County has identified rare plant species within the plan area for which management activities, such as enhancing population sizes or establishing new occurrences, are ongoing or recommended based on low numbers of individuals, low numbers of occurrences, or high risk of threat (table V3.App1A in San Diego Management and Monitoring Program and The Nature Conservancy, 2017). However, the 
genetic diversity and genetic structure of these species are largely unknown, and the MSP identifies conducting genetic surveys as a research need to inform development of implementation plans, planned translocations, seed banking, and other management actions.

Genetic data provide information on plant population status, such as gene flow and adaptive potential, which is useful when planning conservation management strategies (Ellstrand and Elam, 1993; Frankham and others, 2002). Genetic factors, including ploidy and levels of genetic relatedness among individuals, can influence compatibility and survivorship of transplanted individuals or outcrossed offspring (McKay and others, 2005; Gibson and others, 2017). A key genetic concern when faced with restoration choices is determining the appropriate balance between retaining local adaptation and maximizing overall diversity to avoid negative inbreeding effects and retain the ability to respond to future environmental change (Weeks and others, 2011; Harrisson and others, 2014). Understanding population genetic structure can aid in this assessment by estimating the scale over which gene flow occurs and providing information on the distribution of genetic diversity across individuals and occurrences (Hughes and others, 2008; Engelhardt and others, 2014). Here we use the term occurrence to refer to the primary unit of management recognized by the MSP. Following the California Natural Diversity Database definition of an element occurrence, two occurrences are unique if the distance between their closest parts is $\geq 0.25$ miles without regard to whether individuals interbreed (California Natural Diversity Database, 2011). Population parameters that can be estimated with genetic data include genetic differentiation among occurrences, genetic diversity within occurrences, and levels of inbreeding and relatedness among individuals within occurrences (Ottewell and others, 2016).

Genetic differentiation among occurrences comprises the amount of total genetic variation partitioned among occurrences and the genetic distinctiveness of occurrences or groups of occurrences. Genetic differentiation among occurrences can arise over time when gene flow (movement of pollen and seeds) is low among occurrences. This can be due to physical or environmental barriers on the landscape or factors that reduce survivorship and interbreeding among individuals with non-local genotypes (such as differences in ploidy or locally adaptive traits). Gene flow can also be limited spatially, leading to a pattern of isolation by distance (IBD), where genetic differentiation increases as distance between occurrences increases. When gene flow is high among occurrences (and genetic differentiation is low), this may imply a certain level of genetic redundancy across sites, in the sense of ecological redundancy of species contributing to ecosystem resilience (Walker, 1992). Estimating levels of differentiation is useful in selecting sets of compatible occurrences for seed or translocation sources.

Genetic variation provides the raw material for selection and diversification, and the amount of genetic variation contained within a population is closely tied to population size, connectivity, and thus persistence and adaptive potential (Frankham, 2005). Small occurrencesthose founded from just a few individuals or those that undergo frequent or extended genetic bottlenecks - tend to have lower genetic diversity than those that are large or well-connected via gene flow to other occurrences. Low genetic diversity can be correlated with increased extinction risks and low adaptive potential (Spielman and others, 2004; Markert and others, 2010). If genetic diversity is very low, it may be useful to introduce new genetic material to the occurrence to boost genetic diversity and to conduct management activities to support more individuals in situ. When selecting occurrences for seed sources, higher diversity sites might be preferable to lower diversity sites, if genetic similarity among sites is also high. Loss of genetic diversity within sites will also increase the level of divergence between them because of the 
random loss of alleles (genetic drift). Signatures of high genetic divergence and low genetic diversity often occur together (Allendorf, 1986; Slatkin, 1987; Young and others, 1996).

In predominantly outcrossing species, as populations become small it is more likely for close relatives to interbreed or for selfing to occur (Wright, 1938, 1978). Such small populations will have higher levels of inbreeding and relatedness than larger ones with random mating. Breeding between relatives lowers heterozygosity and can reduce the fitness of offspring (inbreeding depression), which can then adversely affect population growth rates (Crnokrak and Roff, 1999; Williams, 2001). Although levels of inbreeding and relatedness can be estimated using genetic information, determining the level of inbreeding depression also requires gathering data on individual fitness (Crnokrak and Roff, 1999).

\section{Study Objectives}

We examined the genetic population structure of six priority plant species throughout the San Diego Management Plan Area (MPA): Acanthomintha ilicifolia, Baccharis vanessae, Chloropyron maritimum ssp. maritimum, Deinandra conjugens, Dicranostegia orcuttiana, and Monardella viminea. With the exception of $D$. orcuttiana, all of these species are federally listed as endangered or threatened. To understand the genetic structure of each of these species, we obtained samples from most known occurrences of the six priority species, developed and analyzed a panel of genetic markers to assess population diversity and divergence, and performed a comparative cytological analysis. Results were then summarized according to a conservation prioritization and decision-making framework (Ottewell and others, 2016) to inform land managers.

Following genetic and cytological analysis, we convened a panel of ecologists and rare plant experts to review results and identify compatible management options for each species relative to their respective MSP objectives. This report includes those options on genetic management of occurrences, addresses MSP objectives involving seed banking and seed bulking needs for each species, and identifies information gaps that, if addressed, could further support management efforts. In addition to supporting regional conservation efforts for the San Diego MPA, these results provide scientific information for the U.S. Fish and Wildlife Service (USFWS) for the five Federally listed species. Finally, these data provide a snapshot for monitoring genetic diversity trends over time in response to future disturbances or restoration actions.

\section{Methods}

\section{Sample Collection}

Samples were collected in the spring and fall of 2016 and the spring of 2017 by the San Diego Natural History Museum (2018). San Diego Natural History Museum botanists attempted to visit and sample from all known occurrences of each priority species within the San Diego MPA. In some cases, additional occurrences were sampled on lands not managed as part of the MSP. These samples were included for analysis context only. Any compatible management options are provided for MSP occurrences.

Collections were made from 20 randomly selected plants from each occurrence, though some occurrences contained fewer than 20 individuals and so fewer were sampled (San Diego Natural History Museum, 2018). Sampled plants were distributed evenly throughout the spatial 
extent of each occurrence. Five plants from each occurrence were further sampled for flow cytometry analysis. Leaf tissue for DNA (deoxyribonucleic acid) extraction was collected into coin envelopes and assigned a unique identifier. Envelopes were stored with color-indicating silica gel desiccant in plastic bins at room temperature. Containers were gently shaken daily to expedite moisture extraction from the leaf tissue. Silica gel beads were changed regularly when fully saturated.

\section{Flow Cytometry}

Fresh leaf tissue was shipped overnight to the U.S. Department of Agriculture (USDA) Forest Service Shrub Science Laboratory in Provo, Utah, for flow cytometric analysis. All samples were run on a Cyflow Space cytometer (Sysmex Corporation) with Atriplex canescens $(1 \mathrm{C}$-value $=1.64 \mathrm{pg}) 2 \times$ or $4 \times$ as an internal standard. The value of each sample was determined by a ratio of the sample peak position to the internal standard peak position, where peak position is indicated by the mean- $x$ value of the designated peaks on the histogram output from the flow cytometer (fig. 1-1). The peak ratio (sample/standard) mean and standard deviation were calculated for each species. Multiple levels of ploidy within species would be suspected if twofold differences in peak ratios were detected.

\section{Genomic Library Preparation}

Genomic DNA was extracted from 15 samples per occurrence. Additional collected samples were used as reserve in case of tissue damage or low yield of DNA following extraction. In total, 1,273 samples were prepared for genetic analysis across all 6 species and 77 occurrences. Extractions were performed using either the Qiagen DNeasy Plant Mini Kit (Qiagen, Valencia, California) or the E-Z $96^{\circledR}$ Plant DNA Kit (Omega Bio-tek Inc., Norcross, Georgia) according to respective manufacturers guidelines, with the addition of a 1-hour room temperature incubation during the first elution. Reduced representation genomic libraries were prepared using a modified double-digest restriction-site associated DNA sequencing (ddRAD) scheme (Peterson and others, 2012). In brief, 300 nanograms (ng) of DNA were cut with EcoRI and SbfI restriction enzymes. In-line barcodes were ligated onto the SbfI cut site, fragments were size-selected on a Pippin Prep (Sage Science, Inc., Beverly, Massachusetts) at a $350 \pm 50$ base pairs (bp) range, and Illumina sequencing adaptors were ligated onto the EcoRI cut site. Each library, containing 16 multiplexed samples, was polymerase chain reaction (PCR) amplified for 14 cycles with the addition of a unique library index sequence and quantified with quantitative PCR (qPCR). This dual index scheme allowed for multiple libraries to be sequenced in a single sequencing lane. In total, 101 libraries were pooled (8-12 libraries per lane, U.S. Geological Survey [USGS] data release https://doi.org/10.5066/P9OWNCG8) into 11-100 bp paired-end HiSeq 4000 lanes (Illumina, Inc., San Diego, California). Libraries were quantified, pooled, and sequenced at the Vincent J. Coates Genomic Sequencing Laboratory at University of California, Berkeley (Berkeley, California).

\section{Genotyping and Analysis}

Raw sequence demultiplexing, quality filtering, and genotyping was performed using the software Stacks v2.0b8 (Catchen and others, 2011) on the USGS Yeti High Performance Computing Cluster. Clustering, assembly, and filtering parameters were optimized for each species using a subset of high coverage individuals, comprised of 25-35 percent of all samples, 
evenly distributed across collection locations, following the $r 80$ method by Paris and others (2017). This sample subset was also used to create the locus catalog (cstacks) for the full Stacks genotyping pipeline. We report the following Stacks parameters for each species: M, maximum number of mismatches between stacks within individuals; $n$, maximum number of mismatches between stacks between individuals; $r$, minimum percentage of individuals in an occurrence required to process a locus for that occurrence; and p, minimum number of occurrences a locus must be present in to process a locus (Catchen and others, 2011). Genetic diversity statistics, including pairwise genetic differentiation $\left(F_{S T}\right)$ expected heterozygosity $\left(H_{e}\right)$, number of private alleles, and inbreeding $\left(F_{I S}\right)$, were calculated using the populations program in Stacks, while filtering for a single bi-allelic single nucleotide polymorphism (SNP) per locus (detailed in Hohenlohe and others, 2010). Specifically, populations used an analysis of molecular variance framework to calculate a nucleotide-level $F_{S T}$ value, a measure of genetic variation within and between sites, between each pair of occurrences (Weir, 1996; Rochette and Catchen, 2017). $H_{e}$, a measure of genetic diversity within site, was calculated as the mean expected frequency of heterozygotes under Hardy-Weinberg conditions (Catchen and others, 2013), and private alleles were considered so if only found in one occurrence. $F_{I S}$, a measure of genetic variation within an individual, was calculated as the degree of difference between observed and expected heterozygotes within occurrences (Wright, 1931, 1978; Catchen and others, 2013). Relatedness ( $r$ ) within each occurrence was calculated using the Queller and Goodnight (1989) estimator, as implemented in the package related v1.0 (Pew and others, 2015) in R v3.3.2 (R Core Team, 2016), to provide further insight into within-site dynamics. To account for missing data, occurrence sample size is presented as an average of the number of individuals with an allele call at each locus.

Genetic clustering analyses were used to explore the pattern of genetic structure in each species. We used two methods, a principal component analysis (PCA) and maximum-likelihood K-means clustering (snapclust; Beugin and others, 2018), to identify differences in allele frequencies across each set of genetic markers. For snapclust, an optimal number of clusters (K) was chosen using both the Bayesian information criterion (BIC) and the Akaike information criterion (AIC), as implemented in snapclust.choose.k. Finally, a mantel test was used to test for a significant pattern of isolation by distance (IBD). Genetic clustering and spatial analyses were implemented in the R package adegenet v2.1.1 (Jombart, 2008). Raw sequence data are available at http://www.ncbi.nlm.nih.gov/bioproject/484956, and final genetic marker datasets for each species are provided as a USGS data release at https://doi.org/10.5066/P9OWNCG8.

\section{Management Ranking and Panel Discussion}

We convened a group of experts to review genetic data results for six rare plant species throughout San Diego County to determine population status and discuss compatible management options and outstanding information needs for occurrences on conservation lands contained within the San Diego MPA. We used a rubric to rank species on a scale of management intensity based on three types of genetic information.

We generally followed the strategies of Ottewell and others (2016) to assign species into management categories using three levels of genetic information with relevance for conservation: genetic differentiation $\left(F_{S T}\right)$ among occurrences, genetic diversity (measured as expected heterozygosity, $H_{e}$ ) and private alleles within occurrences, and inbreeding $\left(F_{I S}\right)$ and relatedness ( $r$ ) among individuals within occurrences (figure 1 in Ottewell and others, 2016). Genetic clustering and IBD results also contributed to determining genetic differentiation among 
occurrences. Additionally, we considered other occurrence characteristics from field data gathered at the time of genetic sample collection or during implementation of the inspect and manage protocol (IMG) for plant occurrence monitoring in the MPA ( San Diego Management and Monitoring Program, 2018a).

\section{Genetic Differentiation Among Occurrences}

First, we ranked genetic differentiation among occurrences as high or low. We used three types of metrics to assess genetic differentiation: pairwise $F_{S T}$, IBD, and genetic clustering (see section “Genotyping and Analysis”). Genetic differentiation was considered high if most estimates of $F_{S T}$ between occurrence pairs were significantly different from zero and (or) if multiple genetic clusters were detected. Isolation by distance was supported if a significantly positive relationship was determined between pairwise genetic distance and the geographic distances between occurrences. Genetic differentiation was considered low if most estimates of FST between occurrence pairs were low and if PCA and clustering methods indicated a single genetic cluster best represented structure across the study area.

\section{Genetic Diversity Within Occurrences}

We ranked genetic diversity within occurrences as low or high based on average expected heterozygosity $\left(\mathrm{H}_{e}\right)$ and number of private alleles (see section "Genotyping and Analysis"). We assigned a rank of high if all assessed occurrences had relatively even average genetic diversity. We assigned a rank of low if one or more occurrences had lower average genetic diversity compared to other sites. We mainly relied on among occurrence comparisons within species because in most cases (with the exception of $C$. maritimum spp. maritimum) we did not have samples from outside of the San Diego MPA to compare. We also attempted to relate any unusually low diversity aggregations with known historical factors such as notably low census size or whether the occurrence was outplanted or natural. Although we could also consider whether average genetic diversity within a particular species was generally high or low in comparison to other species examined in this study, there are several important caveats to comparing across species. Notably, each species was surveyed at a different set of unique loci across the genome. In addition, the species surveyed are not closely related, and so each is subject to a unique evolutionary history, life history traits, and breeding structure that will generally affect genomic diversity (Hamrick and Godt, 1996).

\section{Inbreeding and Relatedness Within Occurrences}

Finally, we examined statistics to determine individual levels of inbreeding or genetic relatedness within occurrences as low or high. We examined coefficients of inbreeding $\left(F_{I S}\right)$ and relatedness $(r)$ among individuals within occurrences. If inbreeding and relatedness coefficients had error bars that included zero, we assumed that inbreeding and relatedness were nonsignificant and met expectations under random mating conditions. We categorized the inbreeding as high if multiple occurrences had inbreeding with values greater than zero. Negative estimates are also possible and can be interpreted as individuals being less related than expected in a randomly mating population. It should be noted that the accuracy of inbreeding and relatedness estimators can be affected by small numbers of markers, small sample sizes within populations, and genotyping errors (Pemberton, 2004; Wang, 2007, 2017). As with genetic diversity, inbreeding and genetic relatedness should be measured against a reference population and should not be compared across species because these measures are highly dependent on the mating 
system, particularly the level of self-compatibility and frequency of self-fertilization. Here, we compared occurrences within species to each other to determine whether any outliers, that may indicate unusual levels of mating between close relatives, were present.

Occurrence Size and Field Data

We compiled existing data for each occurrence of each species for review. These data included estimates of abundance, aspect, soil texture, vegetation community, descriptions of morphological differences among plants within occurrences, and noted disturbance within occurrences (San Diego Natural History Museum, 2018). If available, we also compiled IMG survey abundance and disturbance estimates (San Diego Management and Monitoring Program, 2018a). Disturbances included presence of non-native species, physical disturbance or habitat modifications (trails, trampling, illegal dumping restoration activities), altered hydrology, and recent fire.

Rankings were then discussed using compatible management options (table 1; Ottewell and others, 2016) as a starting guide. Discussion of results for each species centered around two major themes: (1) compatible management actions or strategies that could be applied and (2) existing data or information gaps for each species. Species-specific threats and natural history were taken into account when developing compatible management options.

\section{Results and Discussion}

In general, with the genetic loci we analyzed, we found low genetic differentiation for all species across the San Diego region, with the exception of A. ilicifolia. Relative genetic diversity between occurrences was variable, and average inbreeding values were relatively low and consistent across sites. These findings of panmictic population structure in most species are compatible with a wide array of management options.

\section{Flow Cytometry}

We did not find evidence of multiple levels of ploidy within species. The greatest variation in peak ratios was within $C$. maritimum spp. maritimum (mean $=4.18$; standard deviation $=0.77$ ), but we did not observe a twofold difference between any samples that would indicate doubled (or greater) genome size variation.

Table 1. Mean and standard deviation of flow cytometry peak ratios by species.

\begin{tabular}{|c|c|c|}
\hline SPECIES & $\begin{array}{l}\text { RATIO } \\
\text { MEAN }\end{array}$ & $\begin{array}{c}\text { RATIO } \\
\text { ST. DEV. }\end{array}$ \\
\hline A. ilicifolia & 7.24 & 0.37 \\
\hline B. vanessae & 4.09 & 0.28 \\
\hline $\begin{array}{l}\text { C. maritimum spp. } \\
\text { maritimum }\end{array}$ & 5.19 & 0.77 \\
\hline D. conjugens & 4.18 & 0.44 \\
\hline D. orcuttiana & 3.64 & 0.29 \\
\hline M. viminea & 6.67 & 0.32 \\
\hline
\end{tabular}




\section{Species-Specific Genetic Structure Results and Discussion}

\section{Acanthomintha ilicifolia}

Acanthomintha ilicifolia (Lamiaceae) is an annual herb restricted to clay lenses in San Diego County and northwest Baja California, Mexico. Occurrence size estimates can fluctuate annually, sometimes by an order of magnitude (U.S. Fish and Wildlife Service, 2009a) and are widely variable across the region. Notably, 750,000 individuals were found in Sycamore Canyon in 2017; only 17,500 were found in 2016. Similarly, 15 plants were counted on the southwest slope of McGinty Mountain in 2016, followed by 100 plants in 2017 (San Diego Management and Monitoring Program, 2018a; San Diego Natural History Museum, 2018).

We analyzed 350 individuals from 24 occurrences (fig. 1; table 2-1). Raw 100-bp pairedend sequence reads totaled 806,037,612 with an average of 2,202,288.56 (standard deviation = 926,614.29) paired-end reads per individual. The final genetic marker dataset consisted of 195 independent SNP loci, using the following stacks parameters: $\mathrm{M}=3, \mathrm{n}=3, \mathrm{r}=0.8, \mathrm{p}=18$. Inbreeding was low and consistent across sites, whereas relatedness ranged from 0.16 ( \pm 0.02 SE; standard error) to 0.95 ( $\pm 0.01 \mathrm{SE})$. Genetic diversity $\left(H_{e}\right)$ ranged from $0.007( \pm 0.002 \mathrm{SE})$ at Emerald Pointe to 0.074 ( \pm 0.01 SE) at Bonita Meadows (fig. 2; table 2-1). Genetic differentiation $\left(F_{S T}\right)$ between sites ranged from 0.036 to 0.5 , where pairwise comparisons with Emerald Pointe were among the highest values (fig. 3). Results from genetic clustering analyses showed distinct groupings of occurrences that correspond to geographic regions. A PCA revealed three clusters that correspond to a northern group of occurrences (Palomar Airport, Emerald Pointe, La Costa, and Lux Canyon), an eastern group (Wright's Field, Viejas, Viejas Southwest, and part of La Force Alpine), and a central group that contained the remainder of occurrences (fig. 4). Maximum-likelihood clustering showed five genetic clusters that not only distinguish the northern and eastern groups, but break up the central occurrences into one distinctly southern group and two central groups (fig. 5). The largest occurrence, Sycamore Canyon, contained individuals assigned to all except the northern cluster. A mantel test for IBD revealed a significant correlation between genetic and geographic distance matrices $\left(R^{2}=0.623\right.$; $\mathrm{p}<0.001$; 999 permutations) that is consistent with genetic clustering among geographic regions.

Given low genetic diversity within Emerald Pointe and a small occurrence size estimate (39 plants in 2016; San Diego Natural History Museum, 2018), large among-site differences could reflect genetic drift owing to loss of genetic diversity within this site as well as loss of connectivity with all but the closest neighboring occurrences. Conservation Biology Institute (Conservation Biology Institute, 2018) has binned all known occurrences into "regional population structure" (not to be confused with population genetic structure) categories based on population size, proximity to other occurrences, and management opportunity, among other factors. We found similarities between CBI's categories and genetic clustering in the northern and eastern groupings of occurrences as identified in the PCA, but we also found that the central occurrences are genetically more connected than expected when categorizing based on habitat and size. We found no evidence of multiple levels of ploidy across sampled occurrences (see section "Flow Cytometry"). This is in contrast to a recent study by DeWoody and others (2018) that found cytogenetic variation, in low proportions, within two occurrences adjacent to, but not overlapping with, occurrences we sampled in the northern and eastern regions. DeWoody and other's (2018) eastern occurrence now no longer exists, and we did not have access to the northern occurrence in question. Although our cytology results differ, both studies did find 
evidence of distinct population genetic structure across the region, which is an important consideration when developing an assisted migration plan.

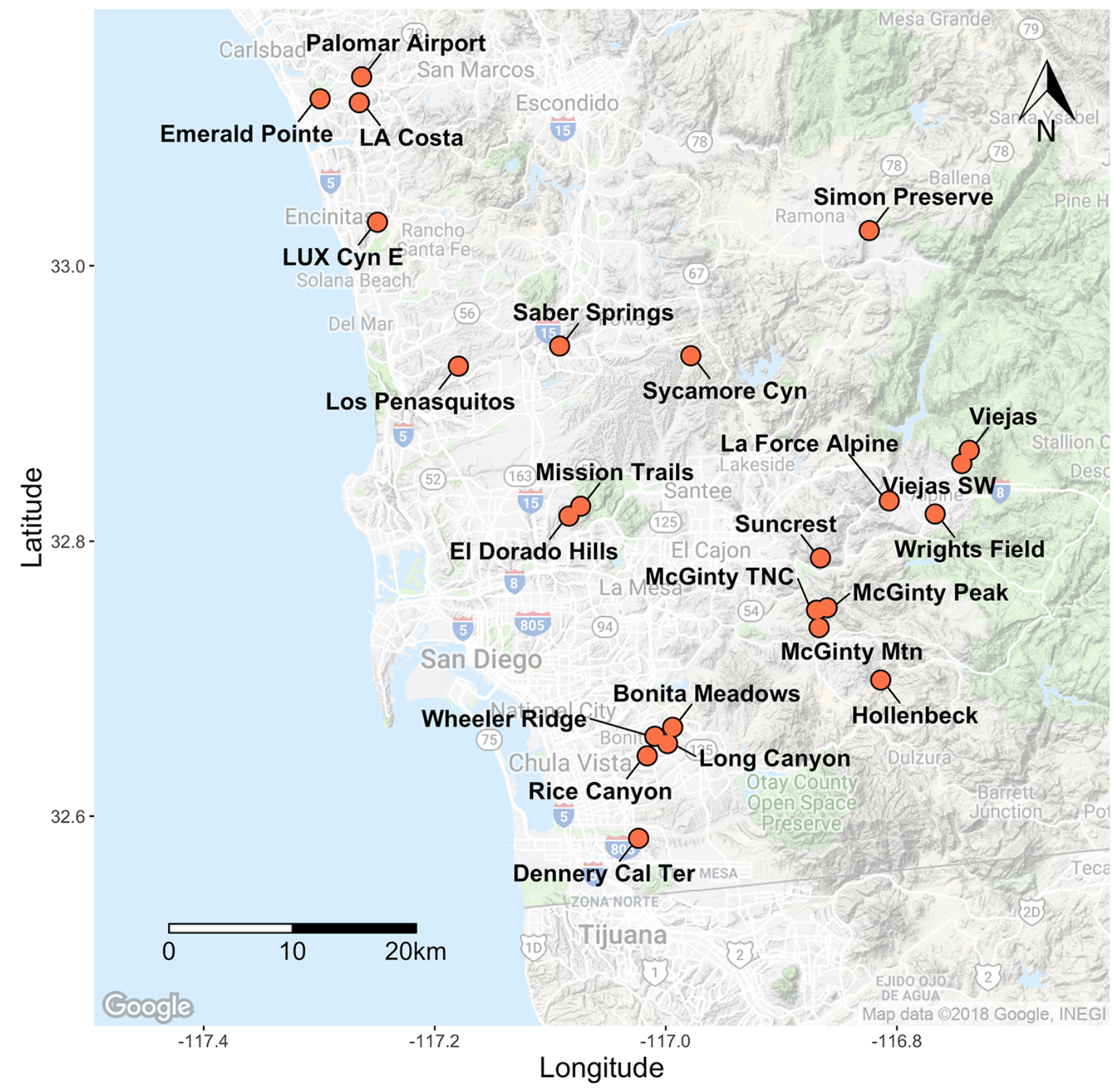

Figure 1. San Diego County map of sampled Acanthomintha ilicifolia occurrences. Cyn, Canyon; E, East; Mtn, Mountain; SW, Southwest; Ter, Terraces; TNC, The Nature Conservancy. 

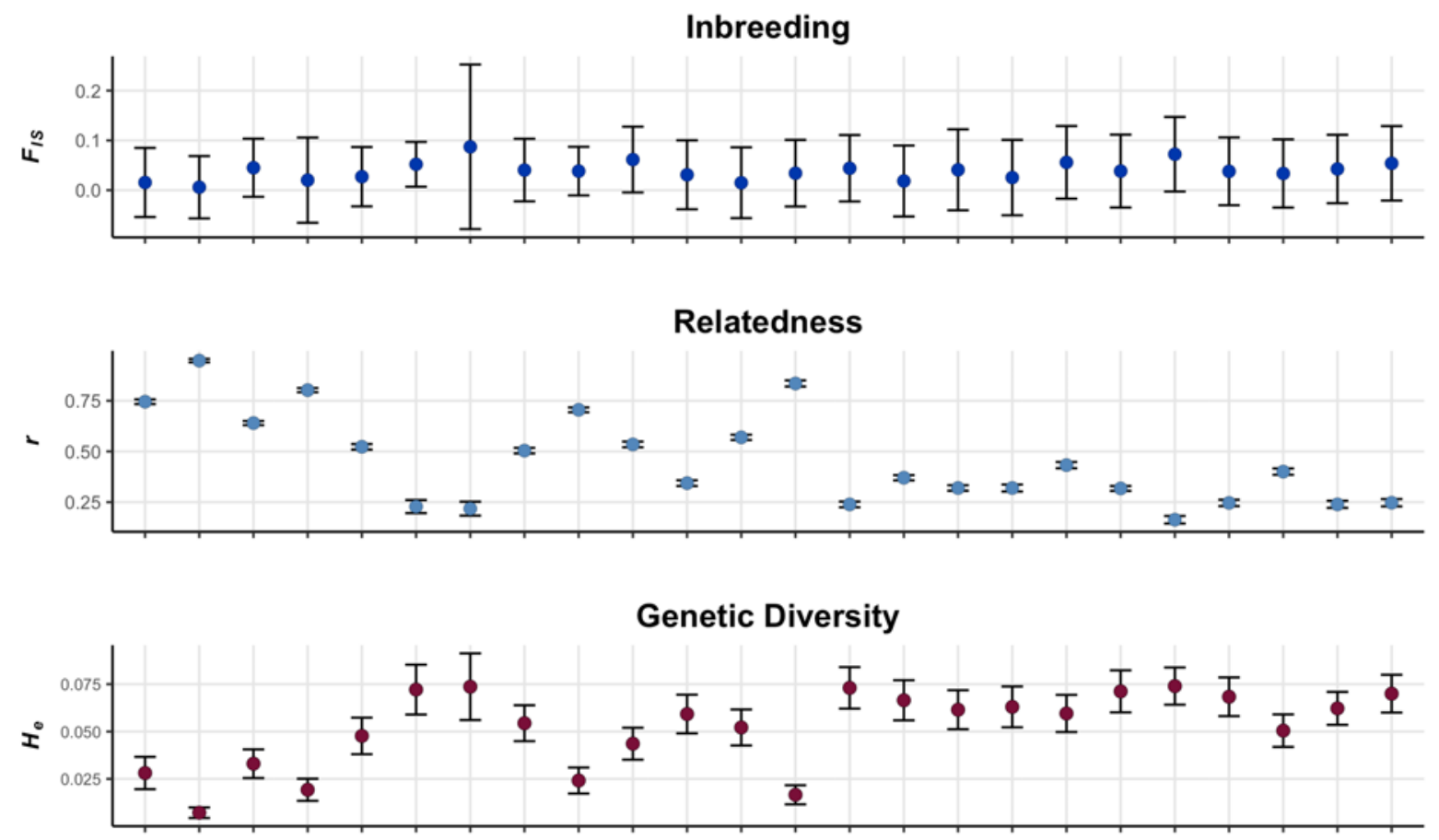

Private Alleles
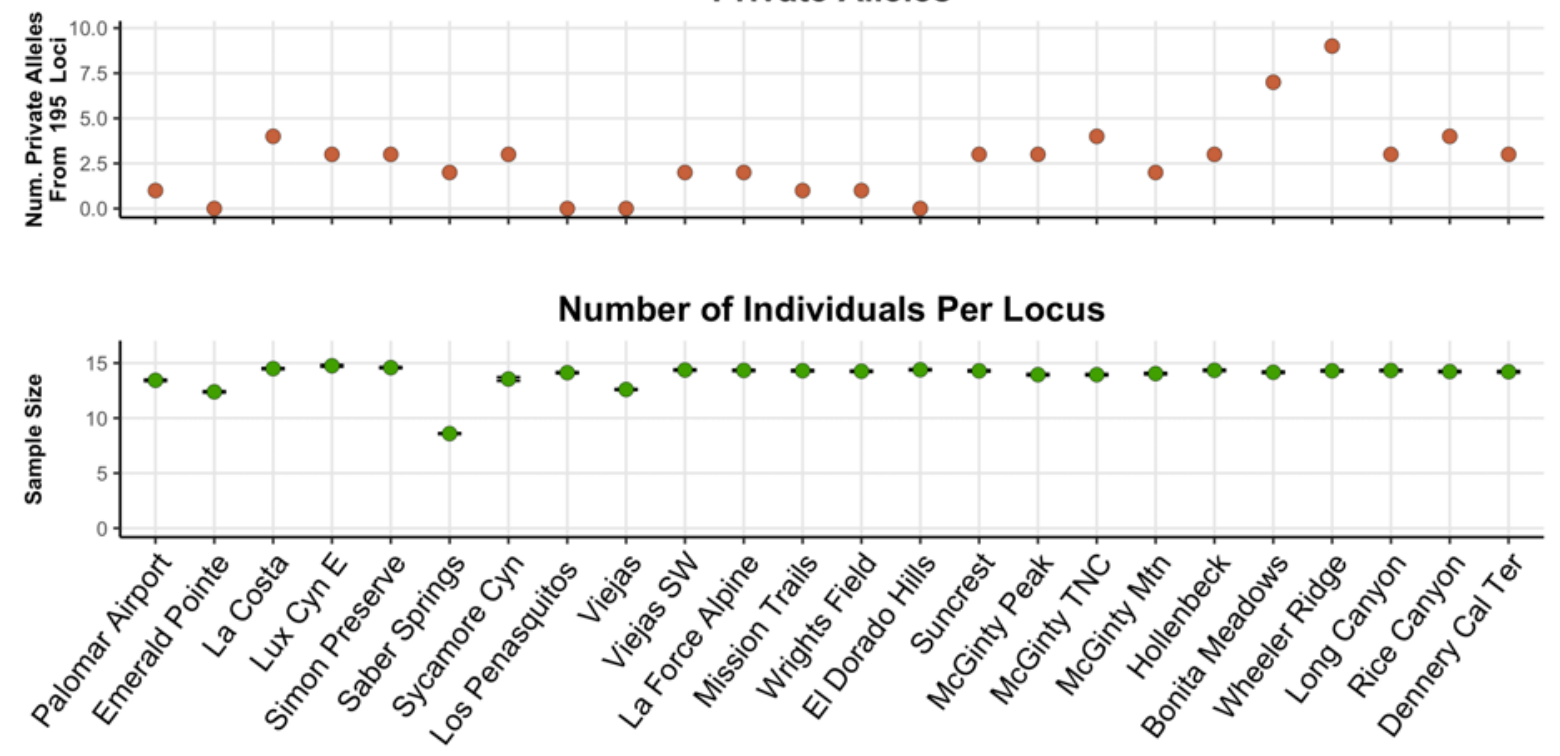

Figure 2. Genetic diversity statistics for Acanthomintha ilicifolia reported as mean values and standard errors for each occurrence. Note the scale is unique to each dataset and should be considered before comparing across plots. Cyn, Canyon; E, East; Mtn, Mountain; SW, Southwest; Ter, Terraces; TNC, The Nature Conservancy. 

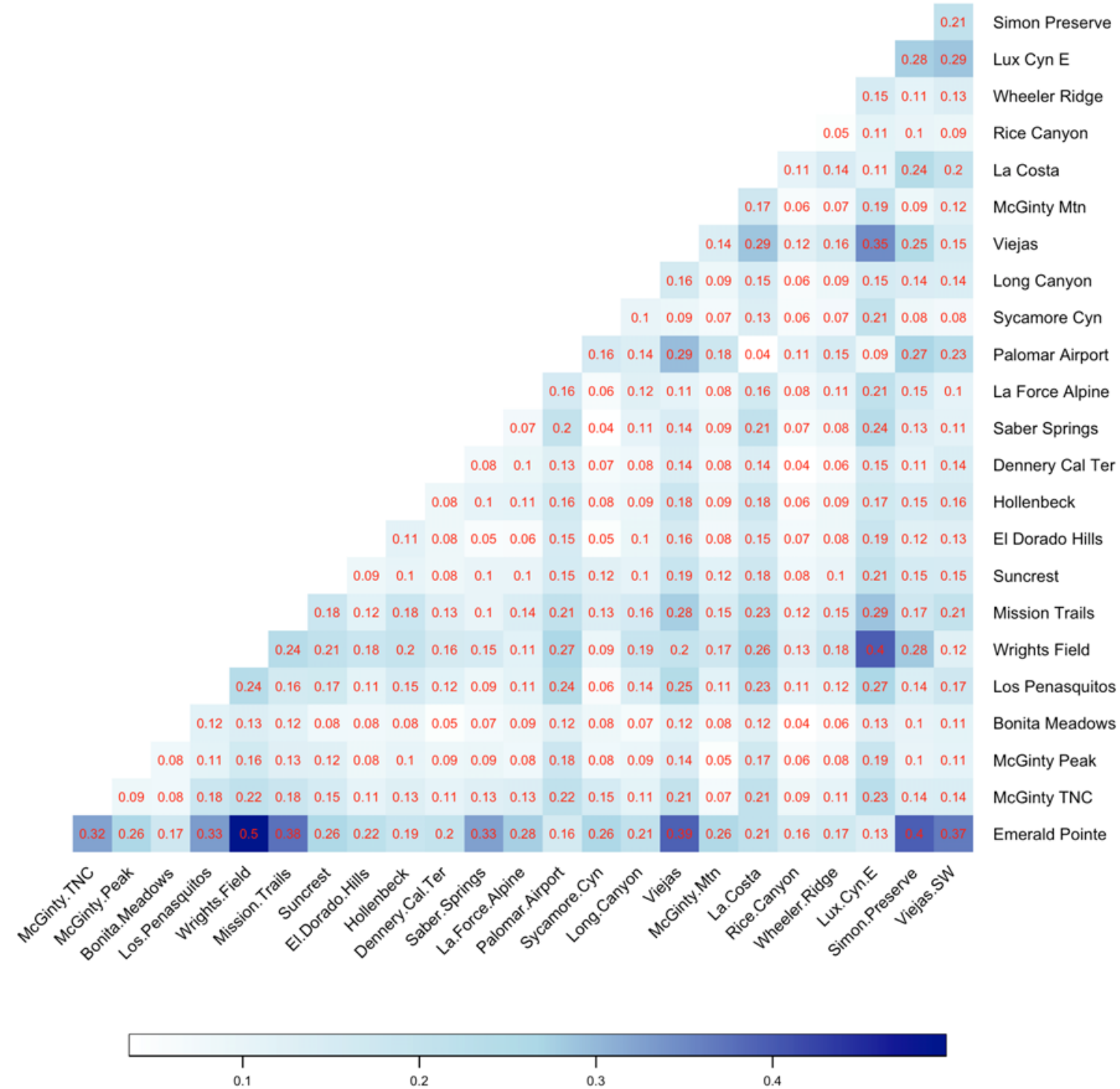

Figure 3. Pairwise FST (genetic differentiation) heatmap for Acanthomintha ilicifolia occurrences. Light color shading represents low genetic differentiation, and dark color shading represents high genetic differentiation; values provided in red. Note color scale is unique to each dataset and should not be compared across species. Cyn, Canyon; E, East; Mtn, Mountain; SW, Southwest; Ter, Terraces; TNC, The Nature Conservancy. 


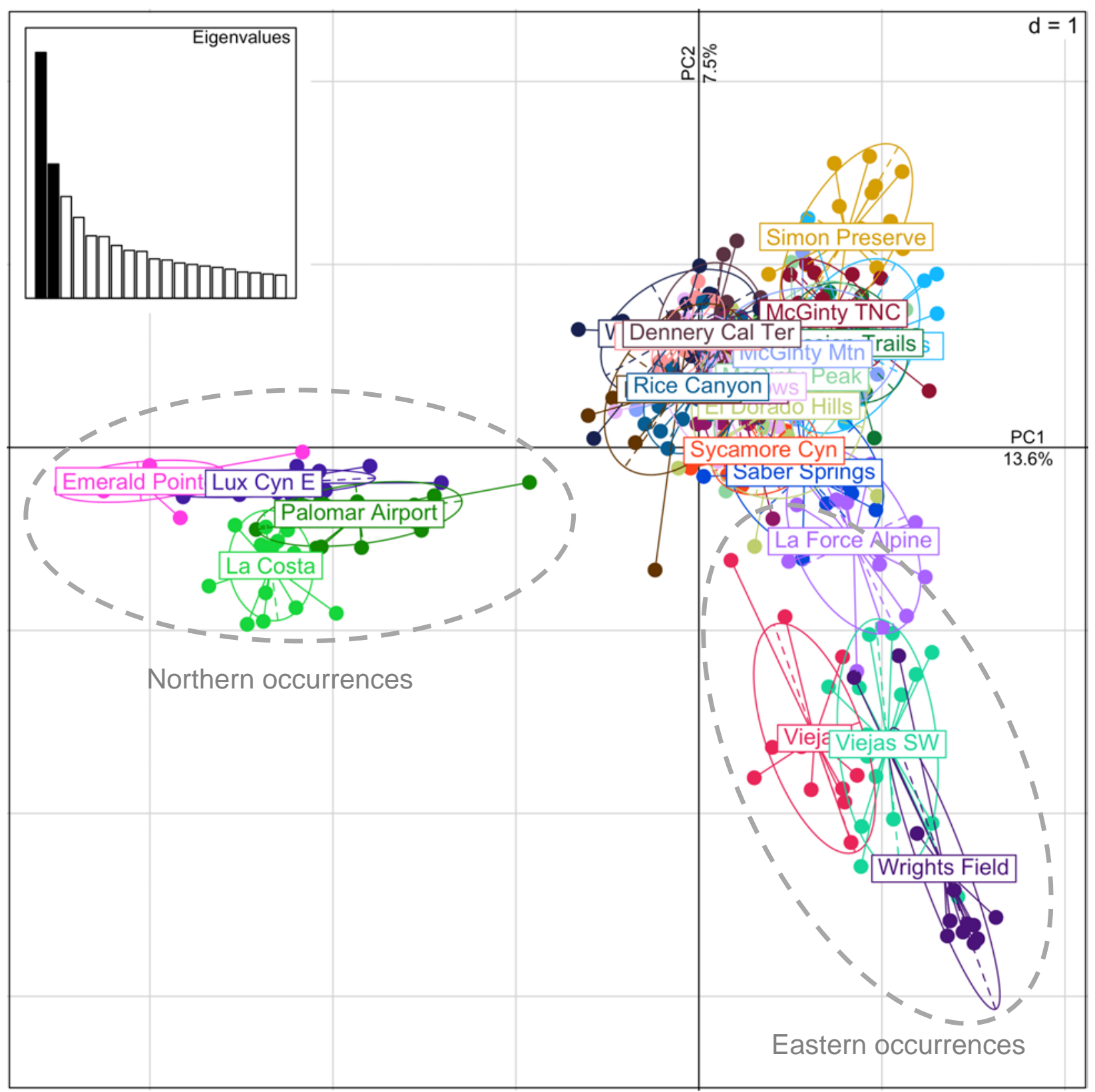

Figure 4. Principal component (PC) plot for Acanthomintha ilicifolia occurrences with PC1 on the horizontal axis and PC2 on the vertical axis. Each point represents an individual sample, and each color and solid ellipse represents an occurrence. Grey hashed ellipses identify occurrences in specific geographic regions. Inset scree plot shows relative values of retained PCs, dimensional grid scale indicated in the upper right corner of main plot. Cyn, Canyon; E, East; Mtn, Mountain; SW, Southwest; Ter, Terraces; TNC, The Nature Conservancy. 


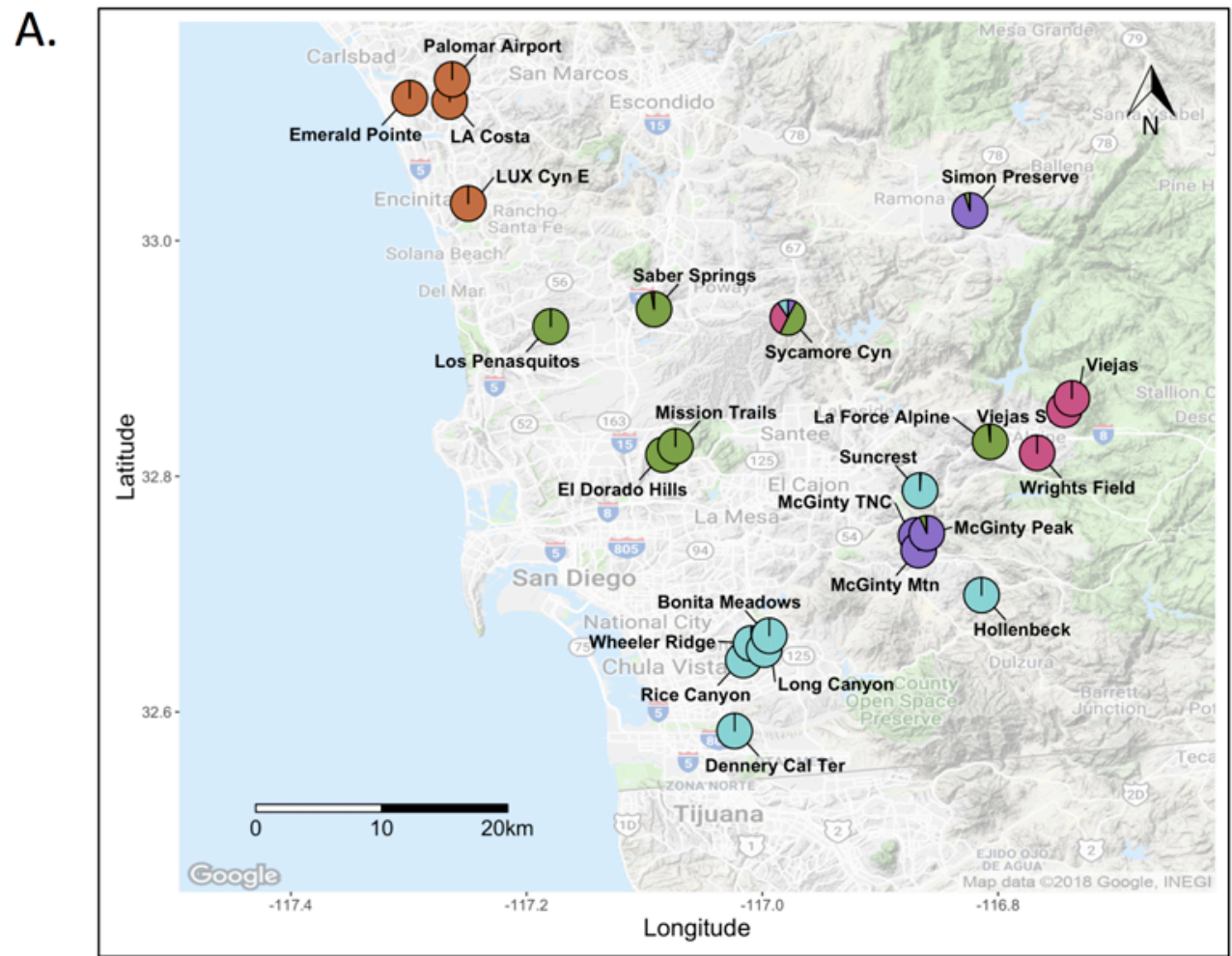

B.

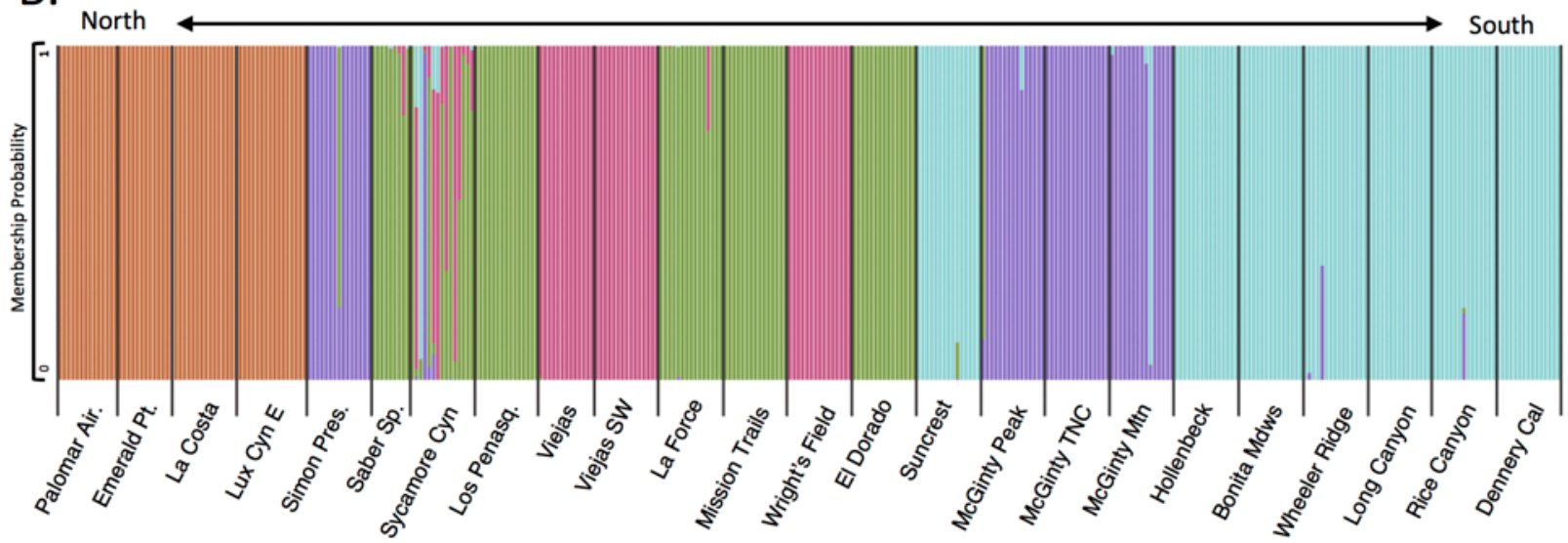

Figure 5. Maximum likelihood membership probability of Acanthomintha ilicifolia where color represents probability of belonging to one of $\mathrm{K}=5$ genetic clusters. $A$, averaged by occurrence on map, and $B$, ordered north to south, where each bar represents an individual. Cyn, Canyon; E, East; Mtn, Mountain; SW, Southwest; Ter, Terraces; TNC, The Nature Conservancy. 


\section{Baccharis vanessae}

Baccharis vanessae (Asteraceae) is an herbaceous dioecious shrub endemic to San Diego County. It occurs in dense chaparral vegetation (Beauchamp, 1980) in a patchy distribution from Marine Corps Base Camp Pendleton (CPEN) in the north to Otay Mountain in the south. Outplanting was attempted at a single site in San Dieguito County Park, but success has not been reported and the occurrence is presumed extirpated (Beauchamp, 1980; U.S. Fish and Wildlife Service, 2011). Recruitment is low at extant sites, and no seedlings have been observed since 1991. This may be due to dependence on regular fire cycles and (or) maintaining viable male and female plants in close proximity (U.S. Fish and Wildlife Service, 2011).

We analyzed 133 individuals from 11 occurrences, 2 of which were newly discovered during this study and located on CPEN (fig. 6; table 2-2). Raw 100-bp paired-end sequence reads totaled 377,644,136 with an average of 2,586,603.67 (standard deviation $=2,711,797.03$ ) paired-end reads per individual. The final genetic marker dataset consisted of 45 independent SNP loci using the following Stacks parameters: $M=4, n=4, r=0.7, p=7$. Inbreeding was effectively zero for all sites, whereas relatedness ranged from -0.05 ( $\pm 0.05 \mathrm{SE})$ to $0.6( \pm 0.03$ $\mathrm{SE}$ ) with the majority of sites falling between 0.4 and 0.6 . Genetic diversity $\left(H_{e}\right)$ was generally low but consistent, ranging from 0.04 ( $\pm 0.02 \mathrm{SE}$ ) at CPEN Devil’s Canyon to 0.09 ( $\pm 0.03 \mathrm{SE}$ ) at Oakcrest Park (fig. 7; table 2-2). Differentiation (FsT) between sites ranged from 0.032 to 0.235 (fig. 8), and though we did not find any distinct genetic clusters (fig. 9) or evidence of isolation by distance, Mount Woodson, Otay Mountain, and Escondido Creek were slightly more differentiated than the main cluster of occurrences.

Baccharis vanessae was only first described in 1980 in and around Encinitas, California (Beauchamp, 1980), but we did not find evidence that occurrences found outside of this locale (that is Otay Mountain and CPEN) were genetically distinct from the central occurrences. This connectivity through gene flow could indicate that there are additional unknown populations or that long distance dispersal can occur. Additional undocumented populations would not be surprising given that $B$. vanessae is somewhat cryptic on the landscape and can be difficult to identify in its preferred dense chaparral environment. Male and female plants can only be differentiated by floral morphology; unfortunately, not all plants were flowering during collection, so we could not compare sex ratios between occurrences. It is concerning that verified recruitment has not been recorded during field visits. Other species of Baccharis are known to have a short seed viability timeframe (U.S. Fish and Wildlife Service, 2011), so we do not expect multiple generations of seeds to be stored in the seedbank. 


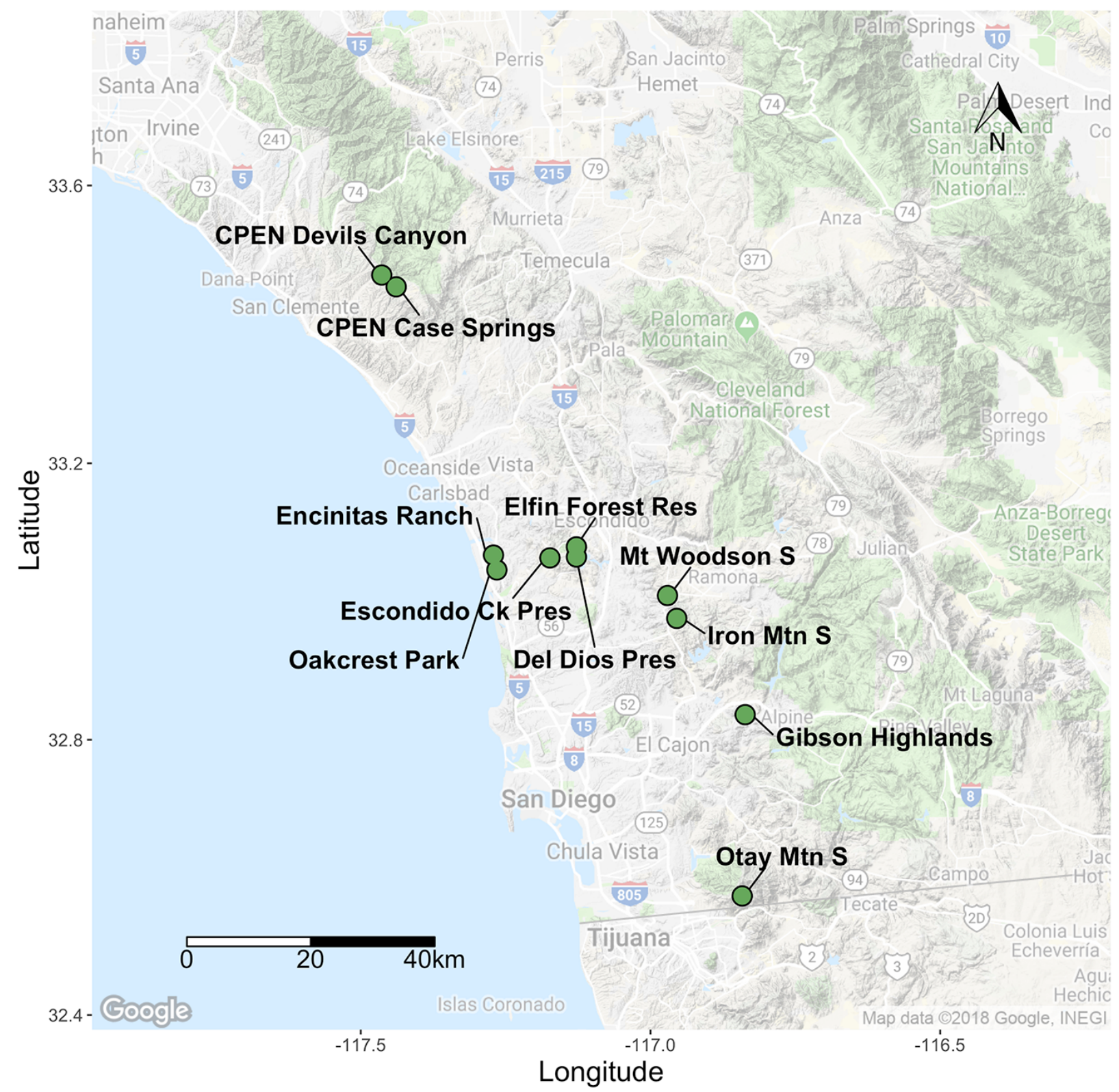

Figure 6. San Diego County map of sampled Baccharis vanessae occurrences. Ck, Creek; CPEN, Marine Corps Base Camp Pendleton; Mt, Mount; Mtn, Mountain; Pres, Preserve; Res, Reserve; S, South. 
Inbreeding
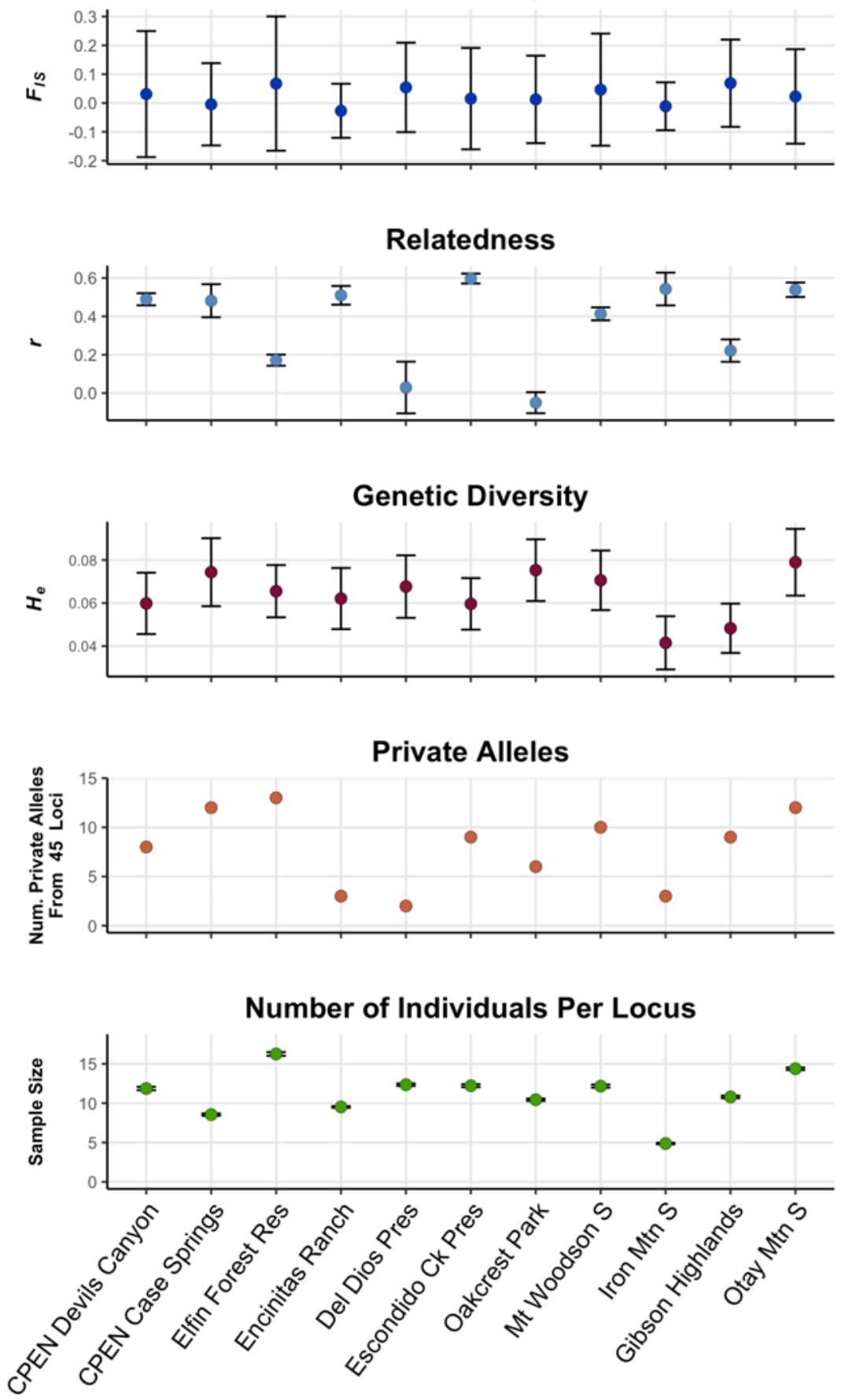

Figure 7. Genetic diversity statistics for Baccharis vanessae reported as mean values and standard errors for each occurrence. Note the scale is unique to each dataset and should be considered before comparing across plots. Ck, Creek; CPEN, Marine Corps Base Camp Pendleton; Mt, Mount; Mtn, Mountain; Pres, Preserve; Res, Reserve; S, South. 


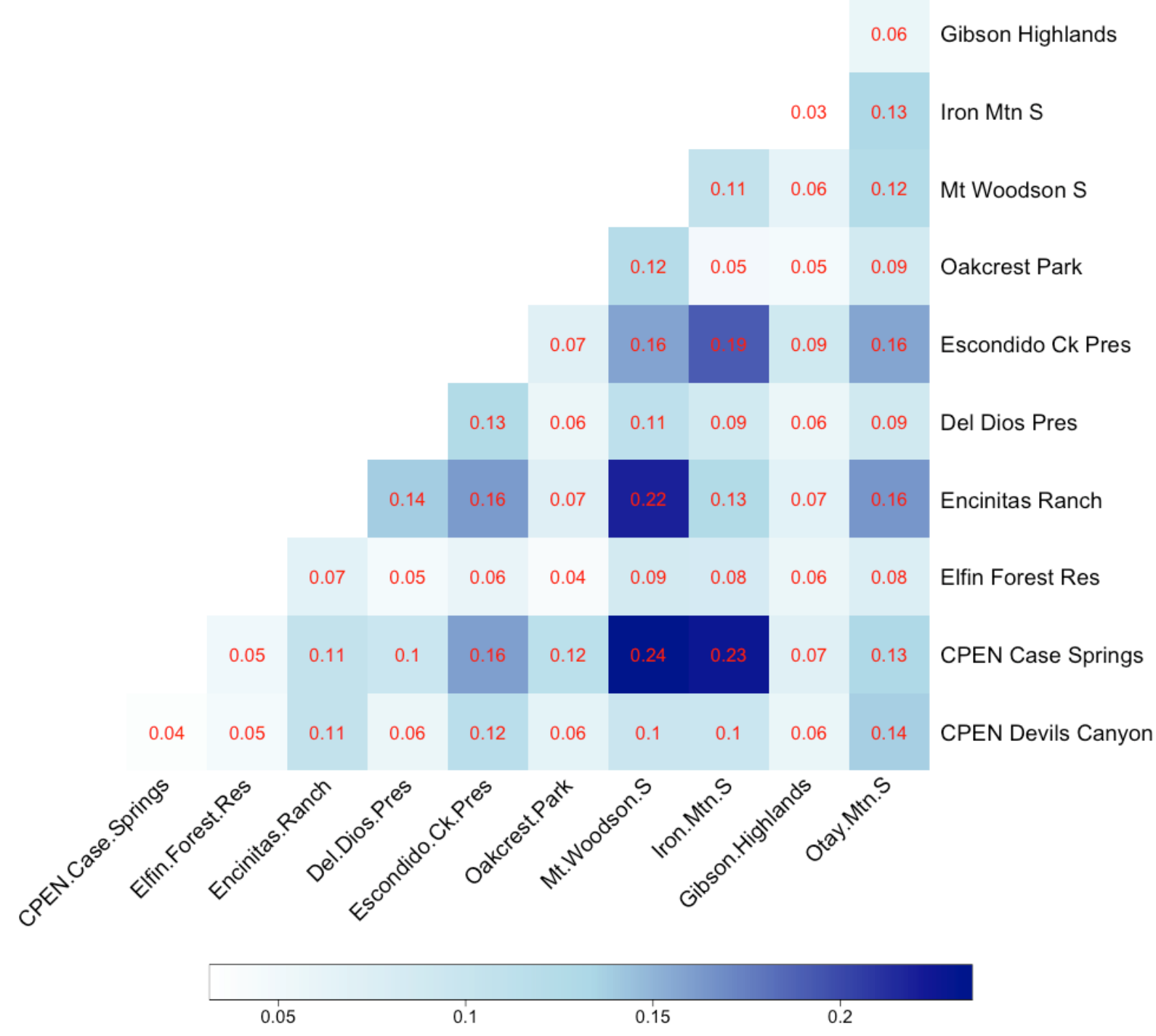

Figure 8. Pairwise $F_{S T}$ (genetic differentiation) heatmap for Baccharis vanessae occurrences. Light color shading represents low genetic differentiation, and dark color shading represents high genetic differentiation; values provided in red. Note color scale is unique to each dataset and should not be compared across species. Ck, Creek; CPEN, Marine Corps Base Camp Pendleton; Mt, Mount; Mtn, Mountain; Pres, Preserve; Res, Reserve; S, South. 


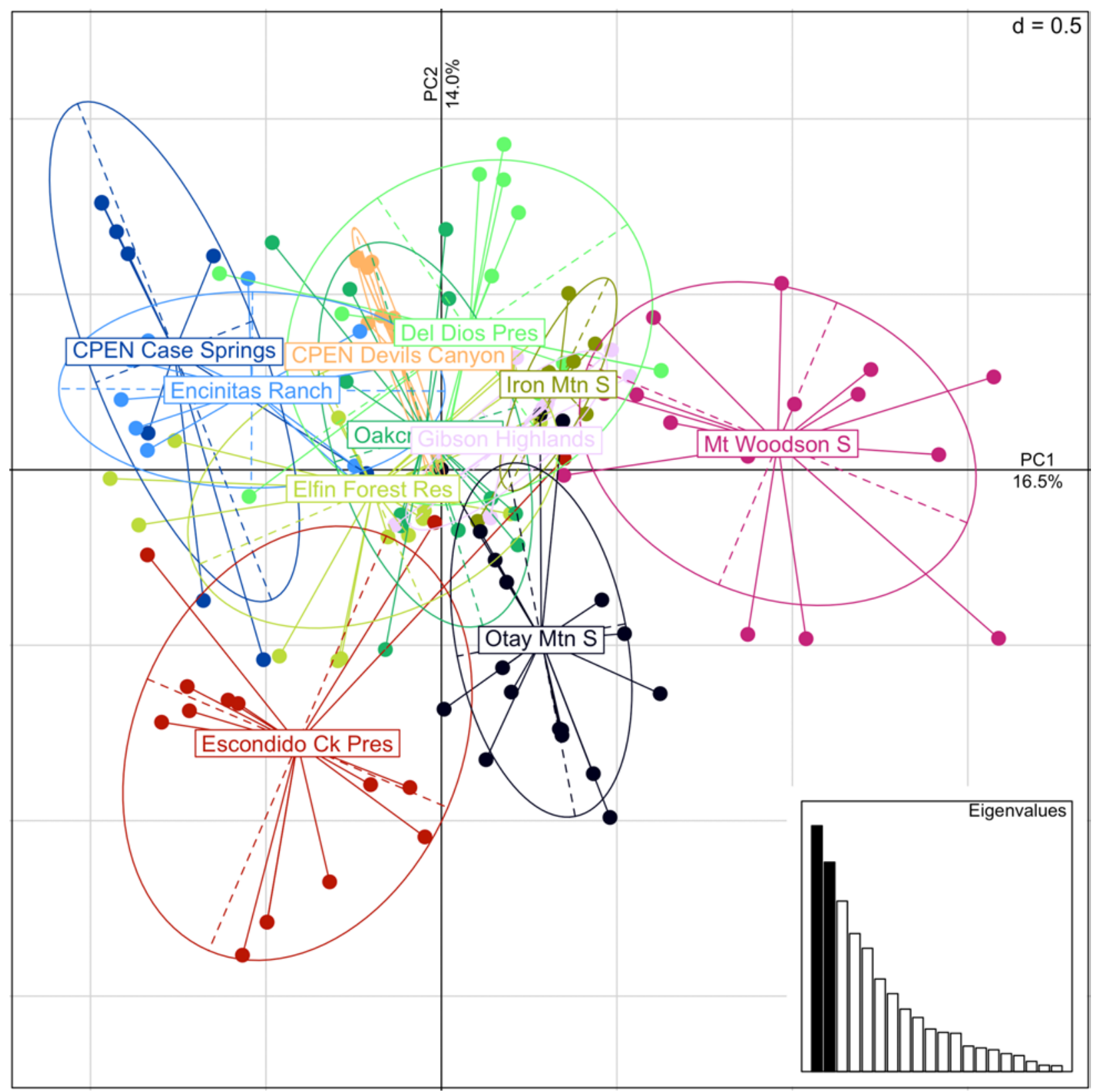

Figure 9. Principal component (PC) plot for Baccharis vanessae occurrences with PC1 on the horizontal axis and PC2 on the vertical axis. Each point represents an individual sample, and each color and ellipse represents an occurrence. Inset scree plot shows relative values of retained PCs, dimensional grid scale indicated in the upper right corner of main plot. Ck, Creek; CPEN, Marine Corps Base Camp Pendleton; Mt, Mount; Mtn, Mountain; Pres, Preserve; Res, Reserve; S, South. 


\section{Chloropyron maritimum ssp. maritimum}

Chloropyron maritimum ssp. maritimum (Orobanchaceae) is a hemiparasitic annual halophyte found in salt marshes from Morro Bay, California, to Punta Azufre in northern Baja California, Mexico. It is self-compatible and pollinated by a number of bee species. Host plant species are unconfirmed and appear to be variable, depending on location (U.S. Fish and Wildlife Service, 2009b). Two reintroduction projects have been attempted in the species, including one at Sweetwater Marsh in San Diego County that was planted with seeds from multiple occurrences around the Tijuana Estuary.

For this species in particular, we obtained samples from all known occurrences in San Diego as well as additional occurrences spanning the range of $C$. maritimum ssp. maritimum from Punta Azufre in Baja California, Mexico, to Morro Bay, California. In total, we analyzed 311 individuals from 22 occurrences across the range; 10 of those occurrences were in San Diego County (figs. 10, 11; table 2-3). Raw 100-bp paired-end sequence reads totaled $592,586,084$ with an average of 1,905,421.49 (standard deviation $=1,424,316.67$ ) paired-end reads per individual. The final genetic marker dataset consisted of 111 independent SNP loci, using the following stacks parameters: $M=4, n=4, r=0.7, p=15$. For the sites located in San Diego County, inbreeding was effectively zero, whereas relatedness ranged from -0.13 ( \pm 0.07 $\mathrm{SE})$ to $0.76( \pm 0.05 \mathrm{SE})$. Genetic diversity $\left(H_{e}\right)$ ranged from $0.015( \pm 0.01 \mathrm{SE})$ at Paradise Marsh to 0.085 ( $\pm 0.04 \mathrm{SE}$ ) at Tijuana Estuary River Mouth (fig. 12; table 2-3). The average $H_{e}$ for San Diego occurrences was 0.052 , in contrast to the rangewide average $H_{e}$ of 0.041 , and the range wide average $H_{e}$ excluding San Diego occurrences of 0.032, indicating that San Diego is a relatively diverse area for this species. Differentiation $\left(F_{S T}\right)$ between sites ranged from 0.001 to 0.32 in San Diego (fig. 13), and we did not find any distinct genetic clusters or evidence of IBD (fig. 14). However, we did find distinct genetic clusters rangewide that correspond to distinct geographic locations. A PCA showed three clusters that correspond to San Diego, Naval Air Station Point Mugu, and all other sites (fig. 15), and maximum-likelihood clustering revealed five distinct clusters that correspond to regional sampling locations (fig. 16).

We found very little evidence of population structure within San Diego County but did observe that genetic diversity is highest for the Tijuana Estuary occurrences, compared to the Sweetwater Marsh transplanting locations and other San Diego marshes. A reintroduction project in Seal Beach, California, closest to the Newport occurrence, was unsuccessful after several attempts (U.S. Fish and Wildlife Service, 2009b), whereas the Sweetwater Marsh reintroduced occurrences still support healthy plants. However, it is especially important to maintain large numbers of individuals at transplanted sites to counteract the effects of genetic drift. Regionwide, we do see evidence of genetic structure tightly correlated with geographic location. Although it is noted that common co-occurring species are found to be influenced by tidal movement, and $C$. maritimum ssp. maritimum seeds can float for up to 50 days (Hopkins and Parker, 1984; U.S. Fish and Wildlife Service, 2009b), many historical occurrences in Los Angeles County, San Bernardino County, and Orange County, including three inland sites, are now extirpated. This has most likely reduced the connectivity of the San Diego occurrences to the more northern locations, though no dispersal studies have been conducted. 


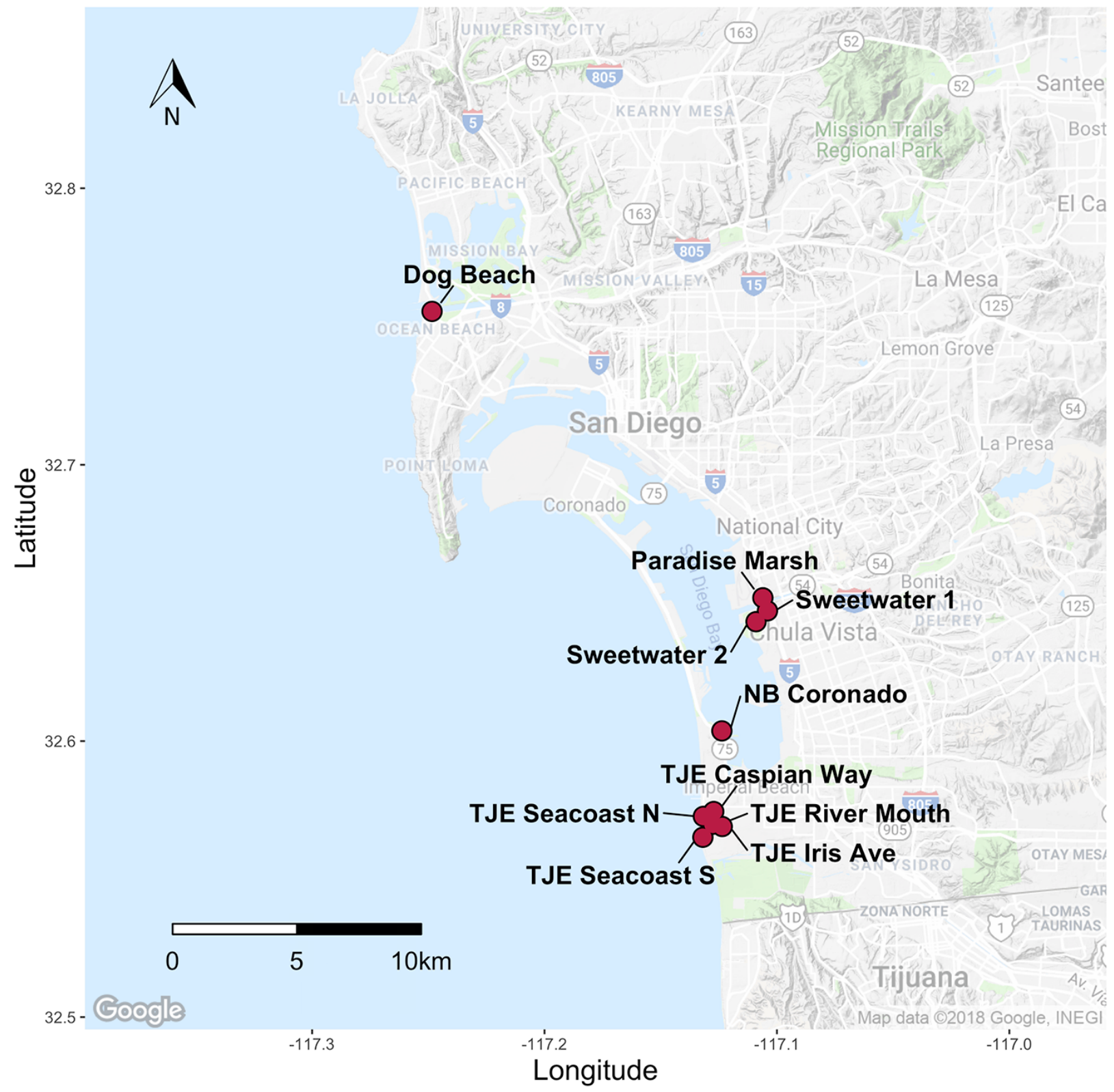

Figure 10. San Diego County map of sampled San Diego Chloropyron maritimum ssp. maritimum occurrences. Ave, Avenue; NB, Naval Base; N, North; S, South; TJE, Tijuana Estuary. 


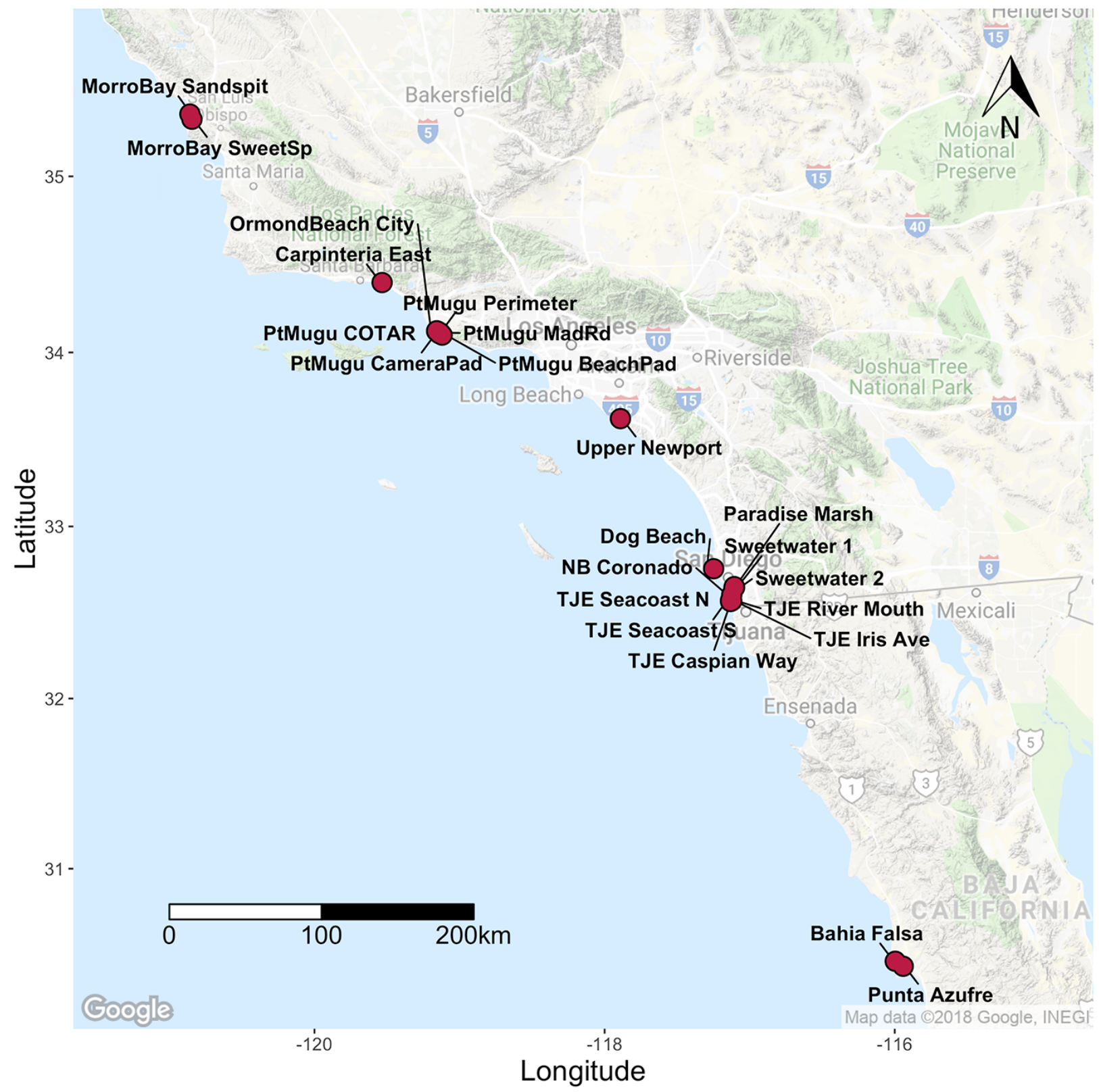

Figure 11. San Diego County map of sampled regional Chloropyron maritimum ssp. maritimum occurrences. Ave, Avenue; NB, Naval Base; N, North; Rd, Road; S, South; TJE, Tijuana Estuary. 

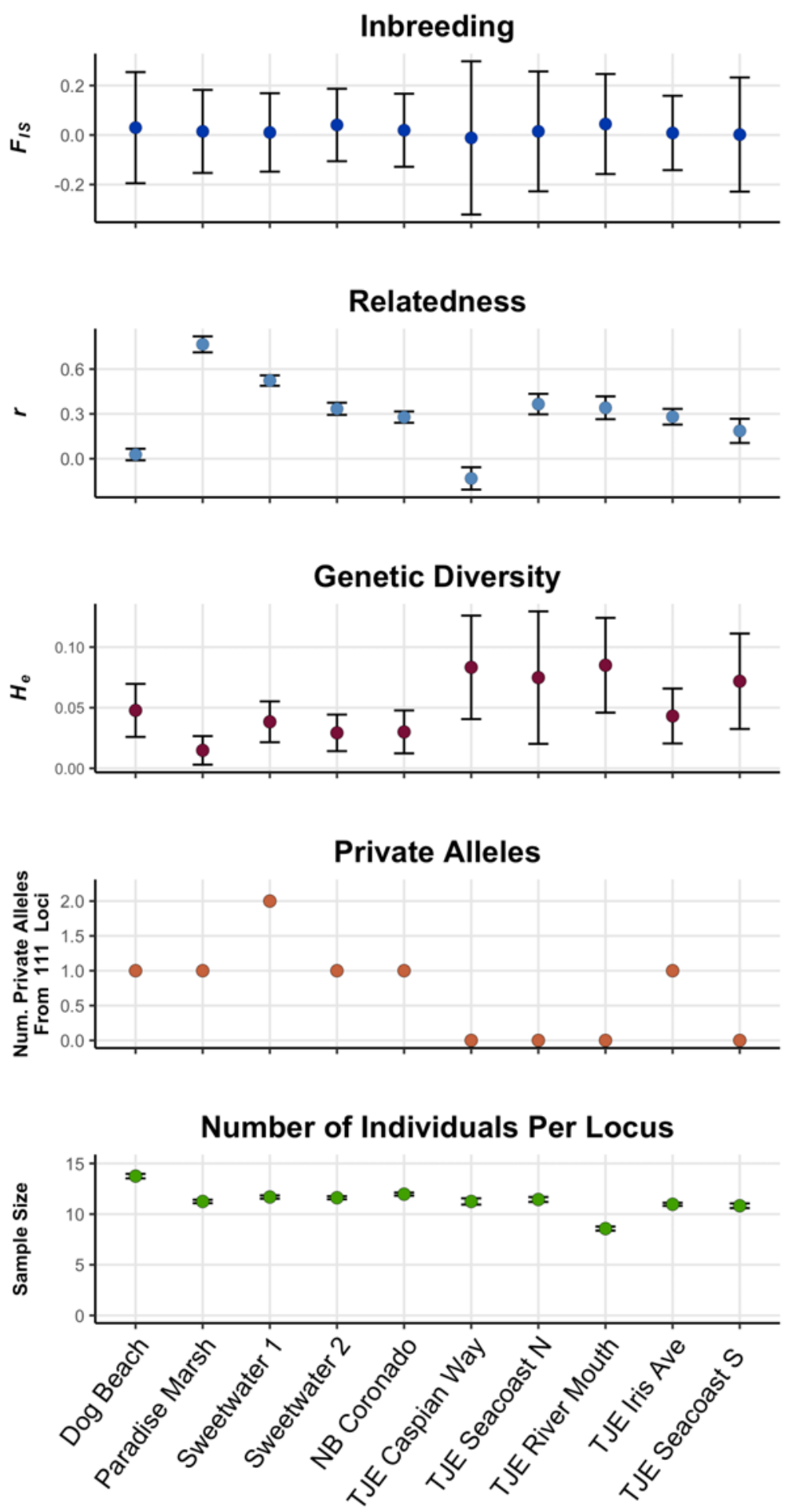

Figure 12. Genetic diversity statistics for Chloropyron maritimum ssp. maritimum reported as mean values and standard errors for each occurrence. Note the scale is unique to each dataset and should be considered before comparing across plots. Ave, Avenue; NB, Naval Base; N, North; S, South; TJE, Tijuana Estuary. 

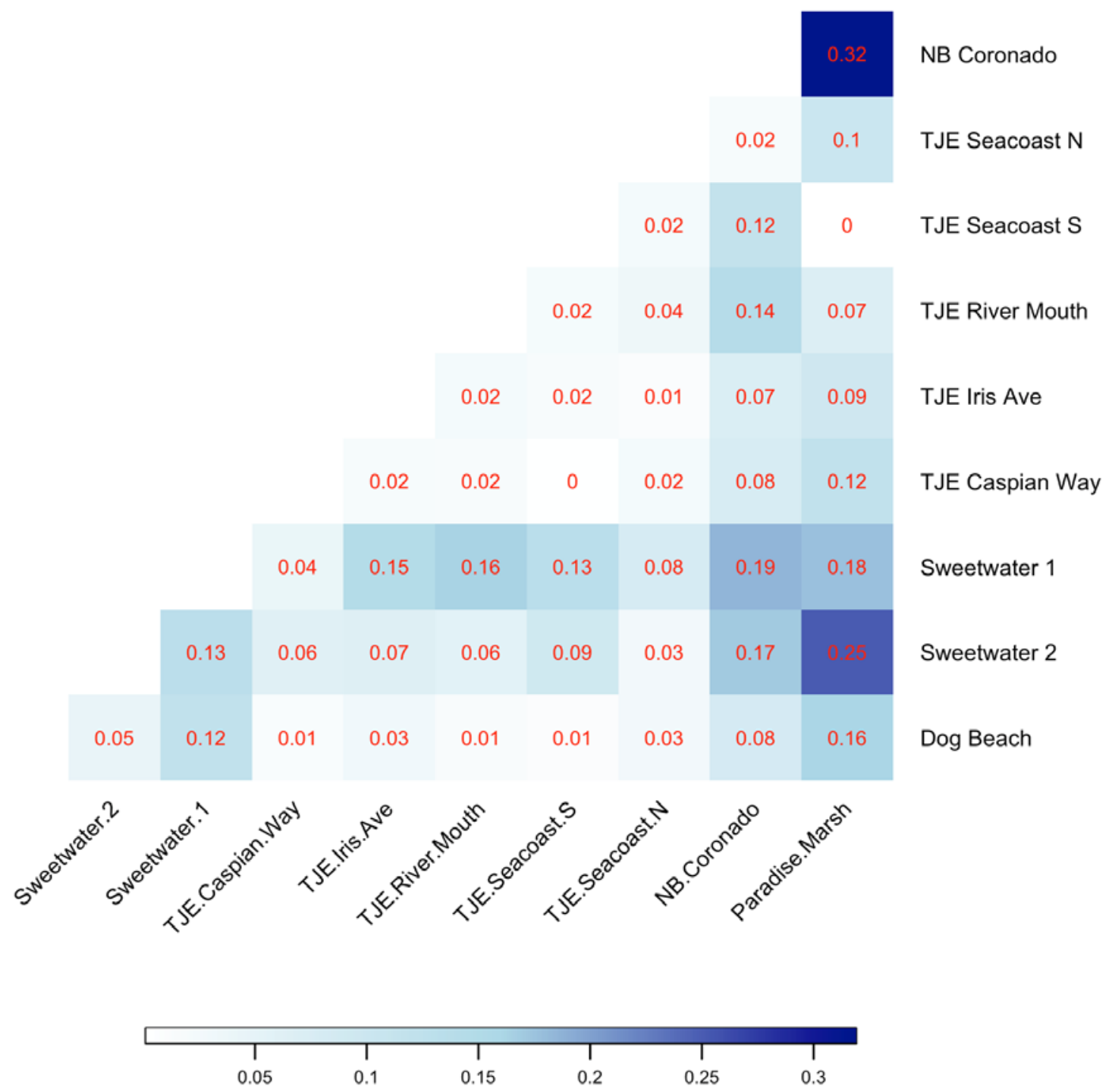

Figure 13. Pairwise $F_{S T}$ (genetic differentiation) heatmap for Chloropyron maritimum ssp. maritimum occurrences. Light color shading represents low genetic differentiation, and dark color shading represents high genetic differentiation; values provided in red. Note color scale is unique to each dataset and should not be compared across species. Ave, Avenue; NB, Naval Base; N, North; S, South; TJE, Tijuana Estuary. 


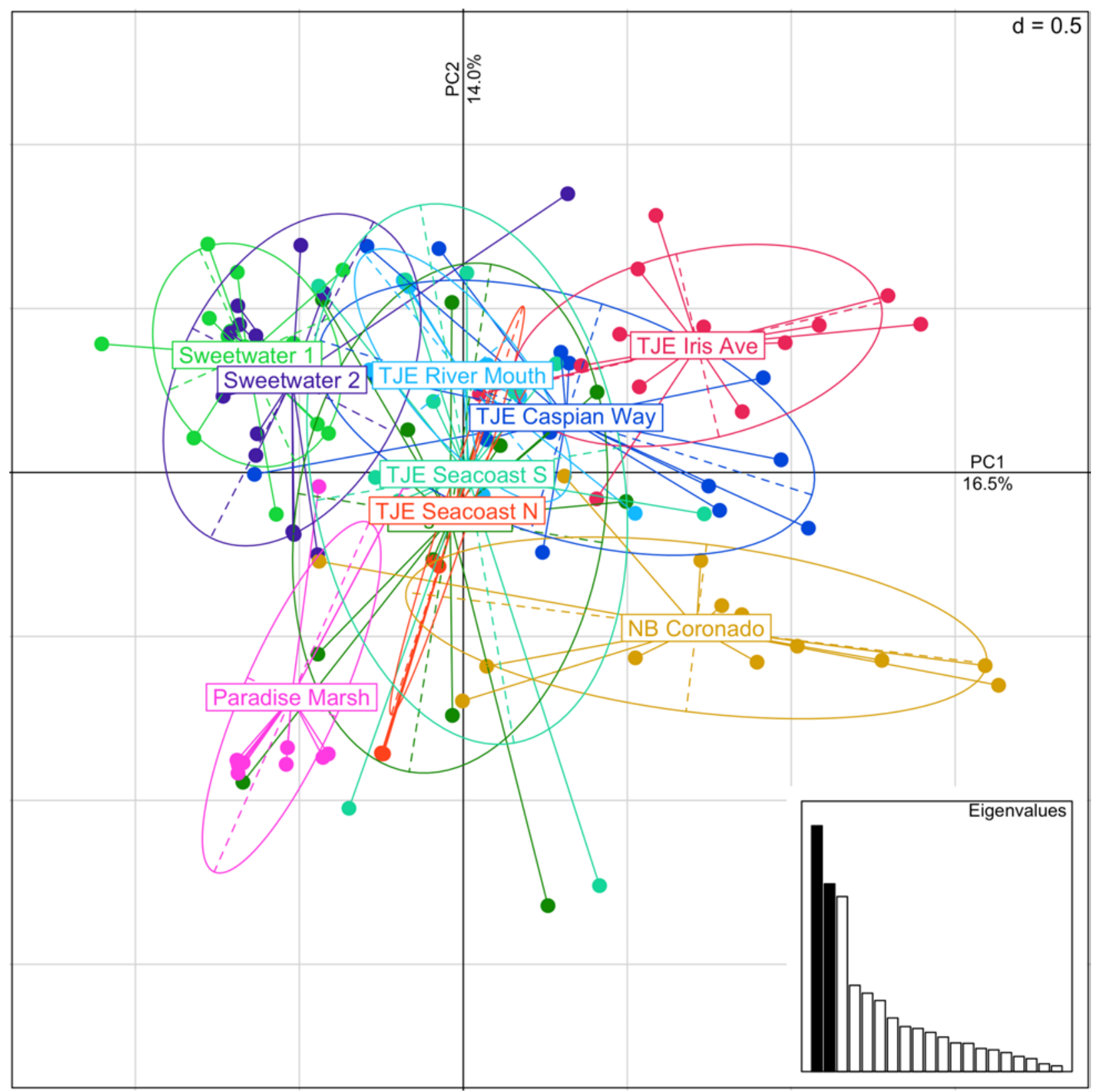

Figure 14. Principal component (PC) plot for San Diego Chloropyron maritimum ssp. maritimum occurrences with PC1 on the horizontal axis and PC2 on the vertical axis. Each point represents an individual sample, and each color and ellipse represents an occurrence. Inset scree plot shows relative values of retained PCs, dimensional grid scale indicated in the upper right corner of main plot. Ave, Avenue; NB, Naval Base; N, North; S, South; TJE, Tijuana Estuary. 


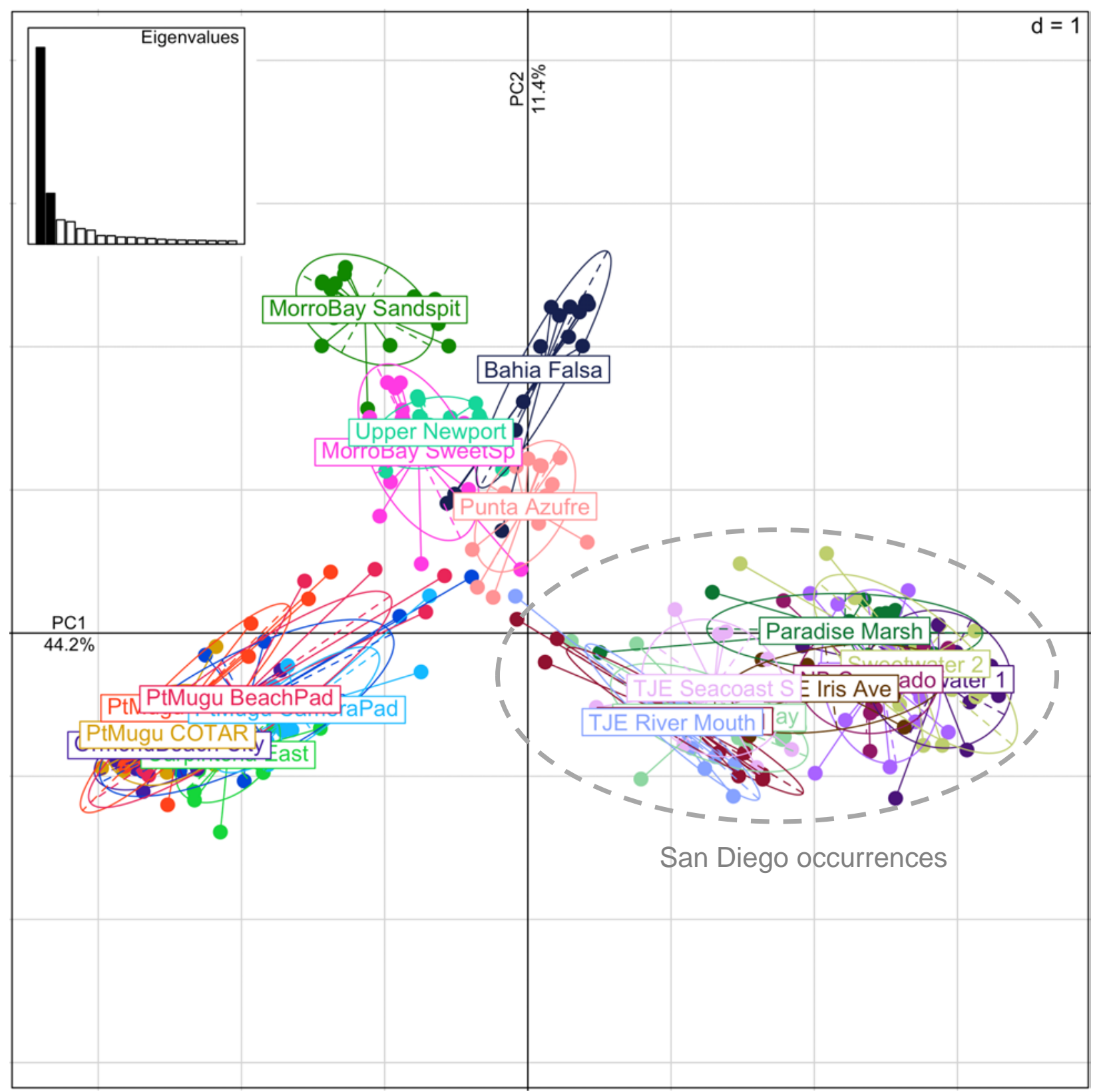

Figure 15. Principal component (PC) plot for regional Chloropyron maritimum ssp. maritimum occurrences with PC1 on the horizontal axis and PC2 on the vertical axis. Each point represents an individual sample, and each color and solid ellipse represents an occurrence. Grey hashed ellipse identifies San Diego occurrences. Inset scree plot shows relative values of retained PCs, dimensional grid scale indicated in the upper right corner of main plot. Ave, Avenue; NB, Naval Base; N, North; Rd, Road; S, South; TJE, Tijuana Estuary. 

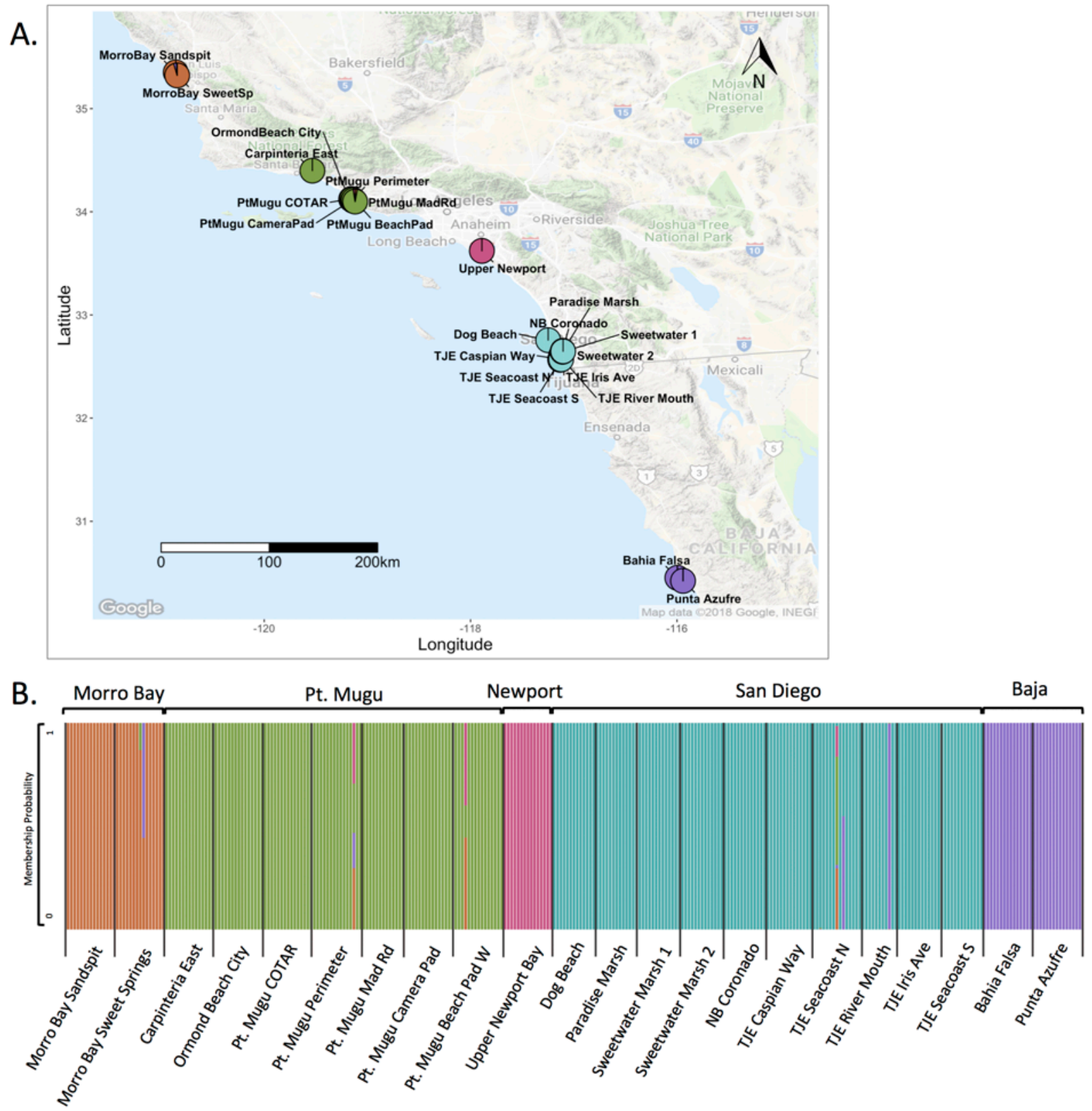

Figure 16. Maximum likelihood membership probability of regional Chloropyron maritimum ssp. maritimum where color represents probability of belonging to one of $\mathrm{K}=5$ genetic clusters. $A$, averaged by occurrence on map, and $B$, ordered north to south, where each vertical bar represents an individual. Ave, Avenue; NB, Naval Base; N, North; Rd, Road; S, South; Sp, Springs; TJE, Tijuana Estuary. 


\section{Deinandra conjugens}

Deinandra conjugens (Asteraceae) is a self-incompatible annual restricted to clay soils in southwest San Diego County and northwest Baja California, Mexico. Population size estimates can fluctuate drastically from year to year (from 0 to 300,000 at a single site over a 5-year period; U.S. Fish and Wildlife Service, 2009c). It co-occurs with D. fasciculata in many locations, but there is no known evidence of hybridization (Bauder and Truesdale, 2000; U.S. Fish and Wildlife Service, 2009c). Sampling for this project was done in a relatively wet year (2016), after 3 years of drought, but the next year (2017) exceeded previous population estimates by orders of magnitude (San Diego Management and Monitoring Program, 2018a). This type of boom and bust cycle could retain a large amount of genetic variation stored in the seed bank for several generations.

We sampled 220 individuals from 16 extant occurrences (fig. 17; table 2-4), where population size estimates ranged from 2 to 50,000 individuals in 2016. Raw 100-bp paired-end sequence reads totaled 623,253,956 with an average of 2,698,069.07 (standard deviation = $2,036,793.65$ ) paired-end reads per individual. The final dataset consists of 40 independent SNP loci, using the following stacks parameters: $M=4, n=4, r=0.7, p=10$. Inbreeding was low and consistent across sites, whereas relatedness ranged from -0.08 ( $\pm 0.07 \mathrm{SE})$ to 0.5 ( $\pm 0.06 \mathrm{SE}$ ) with the majority of sites falling between 0.0 and 0.3 . Genetic diversity $\left(H_{e}\right)$ ranged from $0.02( \pm$ $0.01 \mathrm{SE})$ at PMA3 Poggi Canyon to 0.068 ( $\pm 0.02 \mathrm{SE}$ ) at PMA4 (fig. 18; table 2-4). Differentiation $\left(F_{S T}\right)$ between sites was low and ranged from 0.022 to 0.083 (fig. 19). We did not find any distinct genetic clusters or evidence of isolation by distance (fig. 20).

These results are concordant with a previous genetic study conducted two decades ago. Bauder and Truesdale (2000) sampled three $D$. conjugens occurrences, closest to present day Proctor Valley, San Miguel West, and Dennery Ranch East occurrences, and found substantial genetic diversity within each location and low differentiation among locations $\left(F_{S T}=0.097\right)$. Owing to a large seedbank and boom/bust cycles, occurrence locations can appear to move across the landscape, depending on annual climate. Given these conditions, we conclude that $D$. conjugens has a high rate of gene flow and low risk of outbreeding depression. Conservation Biology Institute (2018) has binned all known occurrences into "regional population structure" categories based on population size, proximity to other occurrences, and management opportunity, among other factors. Because we did not find any distinct genetic clusters or differentiation, we did not find any correlation between this regional population structure and genetic population structure. 


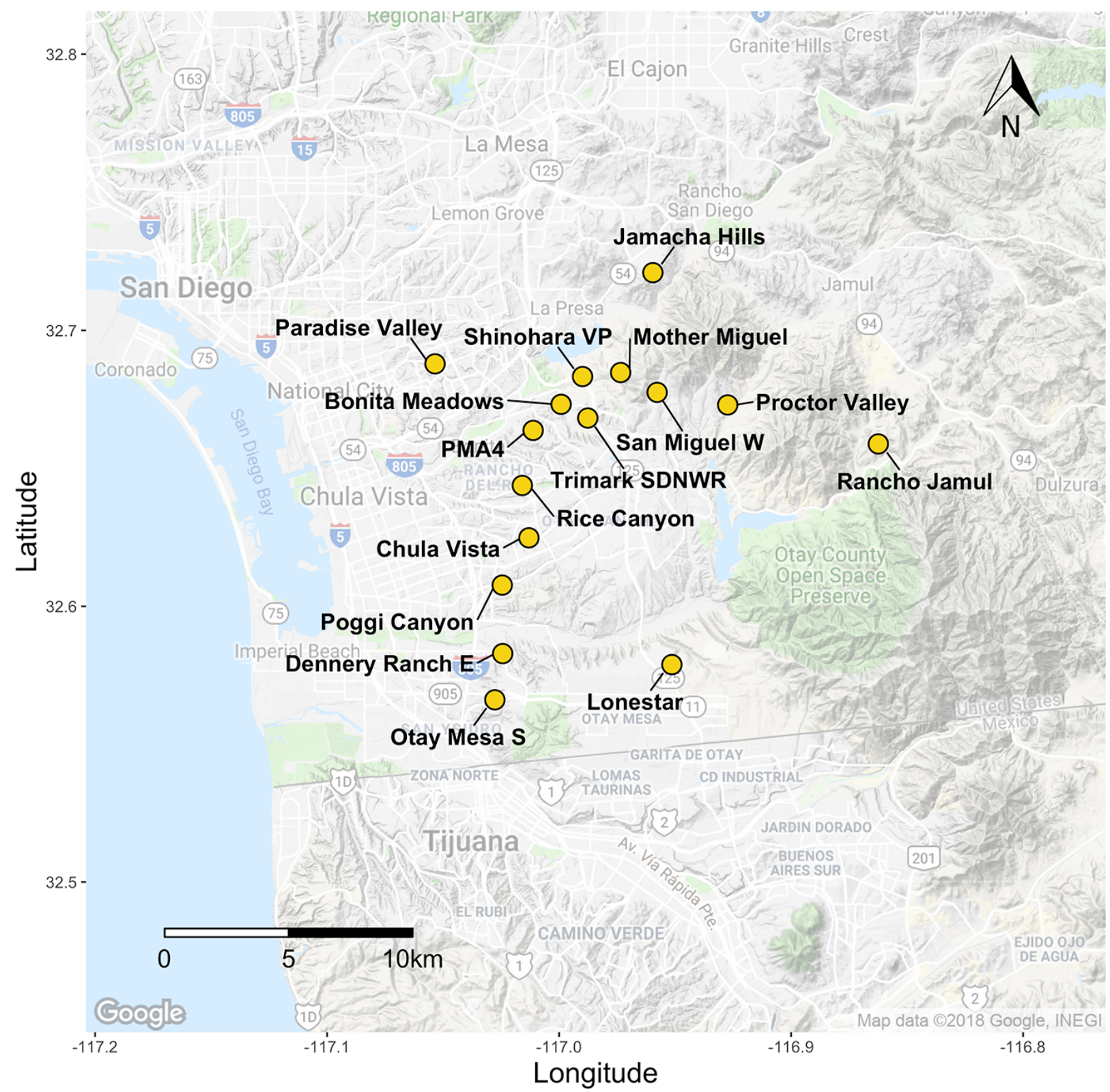

Figure 17. San Diego County map of sampled Deinandra conjugens occurrences. E, East; S, South; SDNWR, San Diego National Wildlife Refuge; VP, Vernal Pool; W, West. 

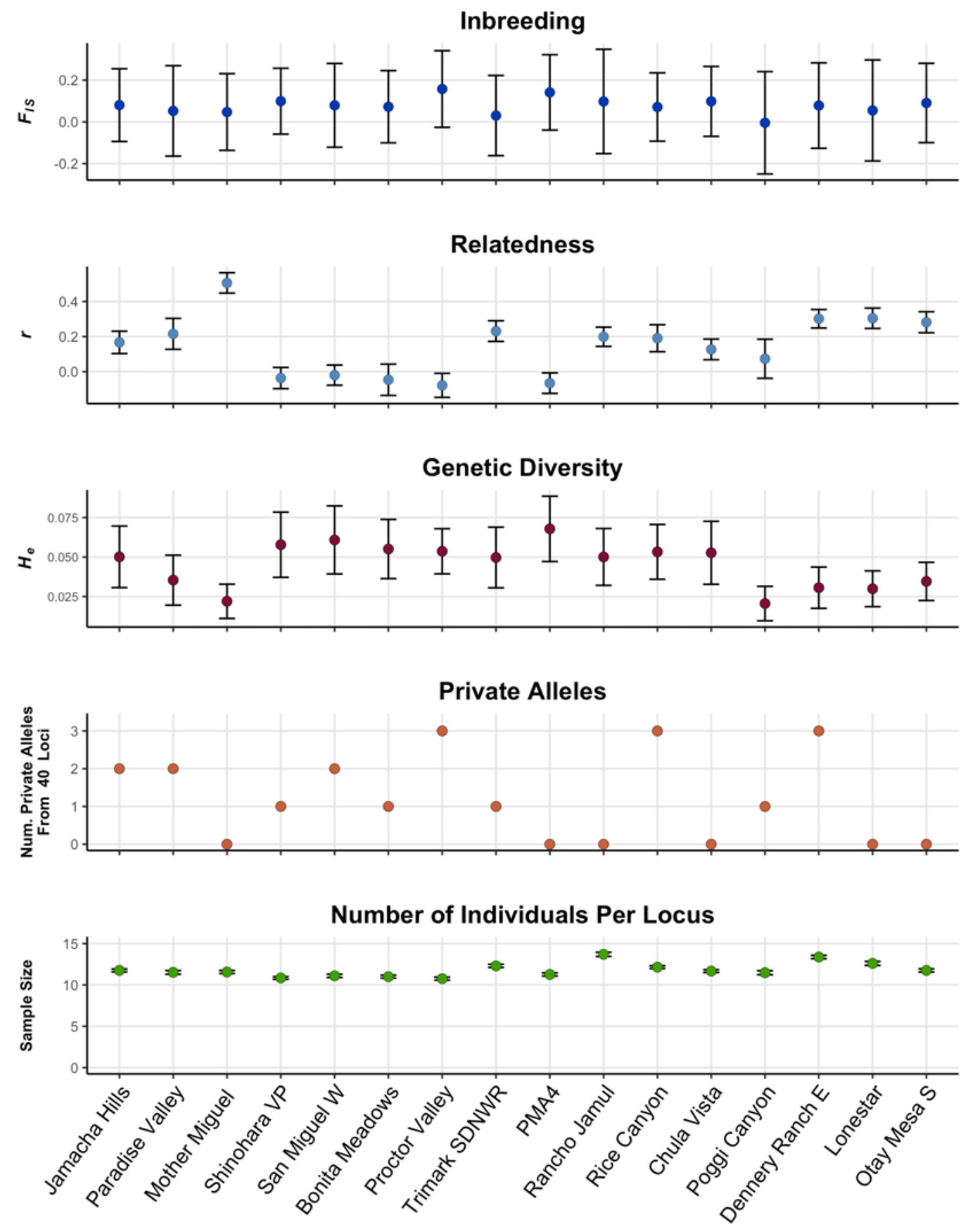

Figure 18. Genetic diversity statistics for Deinandra conjugens reported as mean values and standard errors for each occurrence. Note the scale is unique to each dataset and should be considered before comparing across plots. E, East; S, South; SDNWR, San Diego National Wildlife Refuge; VP, Vernal Pool; W, West. 

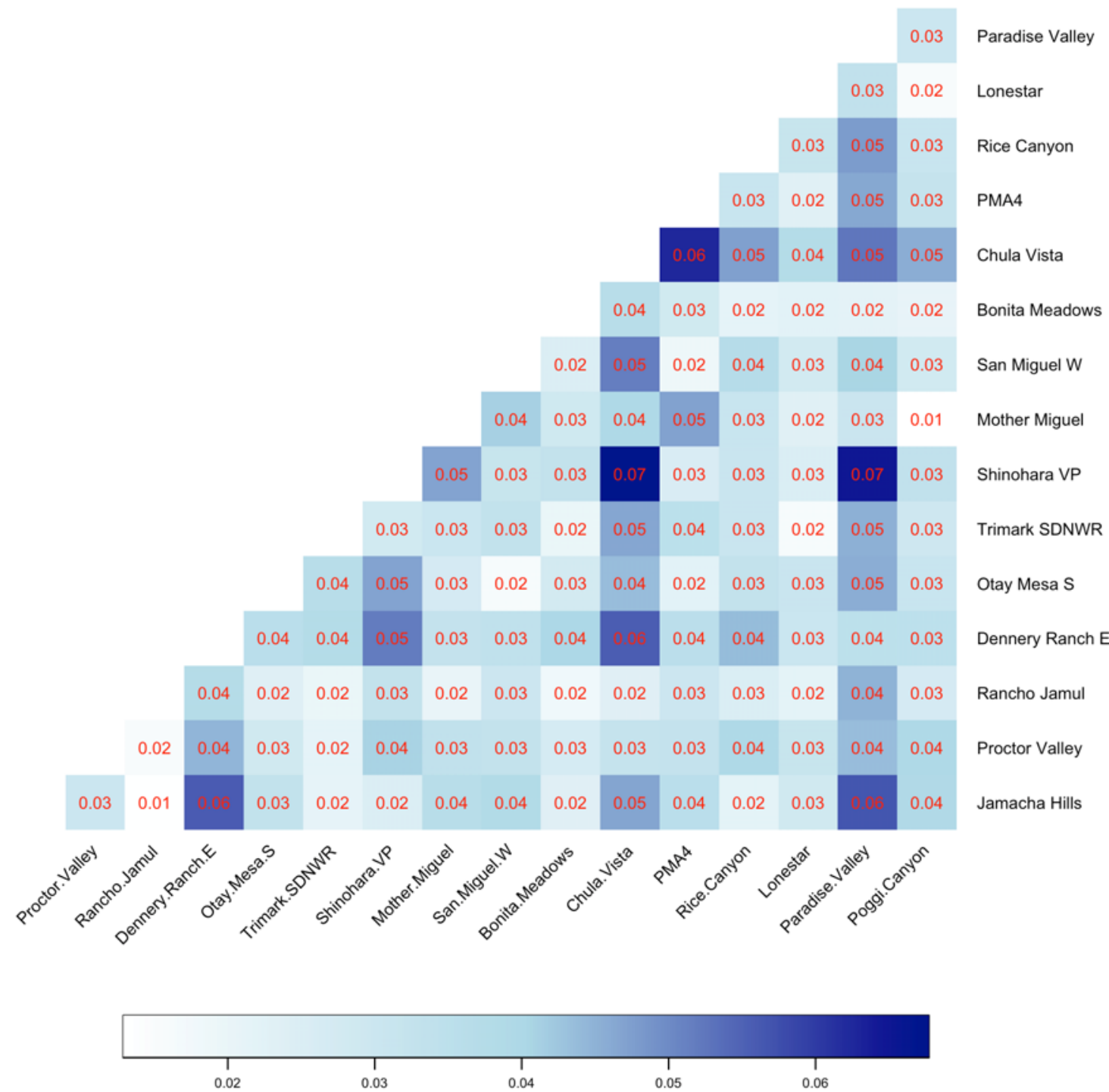

Figure 19. Pairwise FST (genetic differentiation) heatmap for Deinandra conjugens occurrences. Light color shading represents low genetic differentiation, and dark color shading represents high genetic differentiation; values provided in red. Note color scale is unique to each dataset and should not be compared across species. E, East; S, South; SDNWR, San Diego National Wildlife Refuge; VP, Vernal Pool; W, West. 


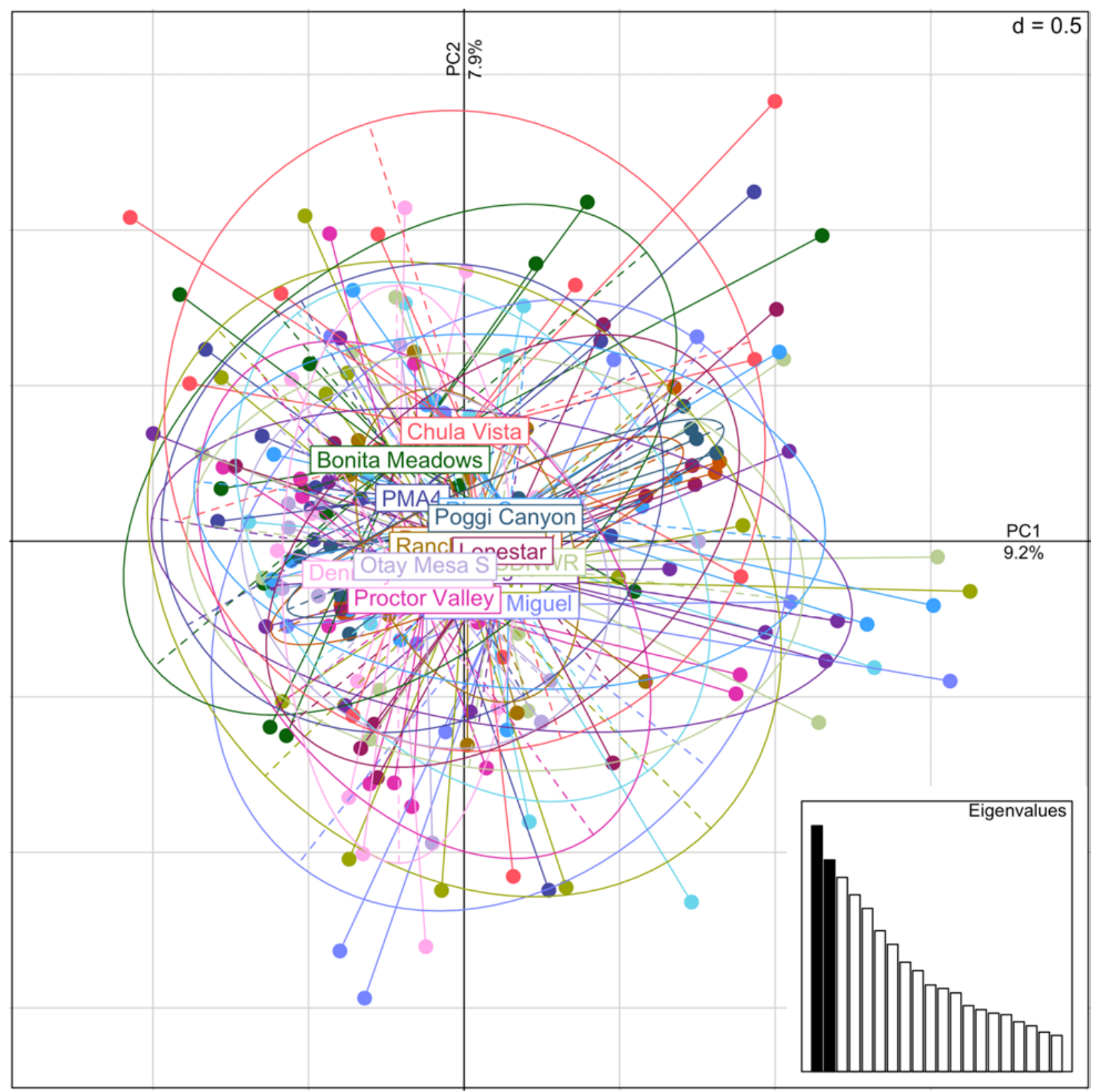

Figure 20. Principal component (PC) plot for Deinandra conjugens occurrences with PC1 on the horizontal axis and PC2 on the vertical axis. Each point represents an individual sample, and each color and ellipse represents an occurrence. Inset scree plot shows relative values of retained PCs, dimensional grid scale indicated in the upper right corner of main plot. E, East; S, South; SDNWR, San Diego National Wildlife Refuge; VP, Vernal Pool; W, West. 


\section{Dicranostegia orcuttiana}

Dicranostegia orcuttiana (Orobanchaceae) is a hemiparasitic annual restricted to sandy soils in southwest San Diego County and northwest Baja California, Mexico. Host species are unknown. There are very few known, extant occurrences in San Diego County, but it is reportedly more common on the Baja peninsula (J. Rebman, oral commun.). Although we obtained samples from one occurrence at Valle Tranquilo, Baja California, Mexico, we were unable to successfully score genotypes for any individuals from that location.

We analyzed 89 individuals from 5 occurrences in San Diego (fig. 21; table 2-5), where population size estimates ranged from 5 to 10,000 individuals in 2016. Raw 100-bp paired-end sequence reads totaled 294,576,621 with an average of 2,779,024.73 (standard deviation = $1,785,049.42$ ) paired-end reads per individual. The final genetic marker dataset consisted of 74 independent SNP loci, using the following stacks parameters: $M=4, n=4, r=0.6, p=3$. Inbreeding was variable across sites, ranging from 0.08 to 0.26 , but the margin of error was large enough for all sites that no distinction can be made. Relatedness ranged from $-0.05( \pm 0.03 \mathrm{SE})$ to $0.36( \pm 0.03 \mathrm{SE})$. Genetic diversity $\left(H_{e}\right)$ ranged from $0.091( \pm 0.02 \mathrm{SE})$ at Borderfield State Park to 0.142 ( \pm 0.02 SE) at Cal Terraces (fig. 22; table 2-5). Genetic differentiation (FST) between sites was low and ranged from 0.03 to 0.1 (fig. 23). We did not find any distinct genetic clusters or evidence of isolation by distance (fig. 24).

There are few known occurrences of $D$. orcuttiana in San Diego, but new occurrences were found for this study using historical data (San Diego Natural History Museum, 2018). This plant can be inconspicuous on the landscape, so it is possible that previous surveys have missed identifying it in the field. Because it is reportedly more common in the Baja peninsula, San Diego County appears to be a range edge for the species. Range edges typically have reduced genetic variation compared to a population center. 


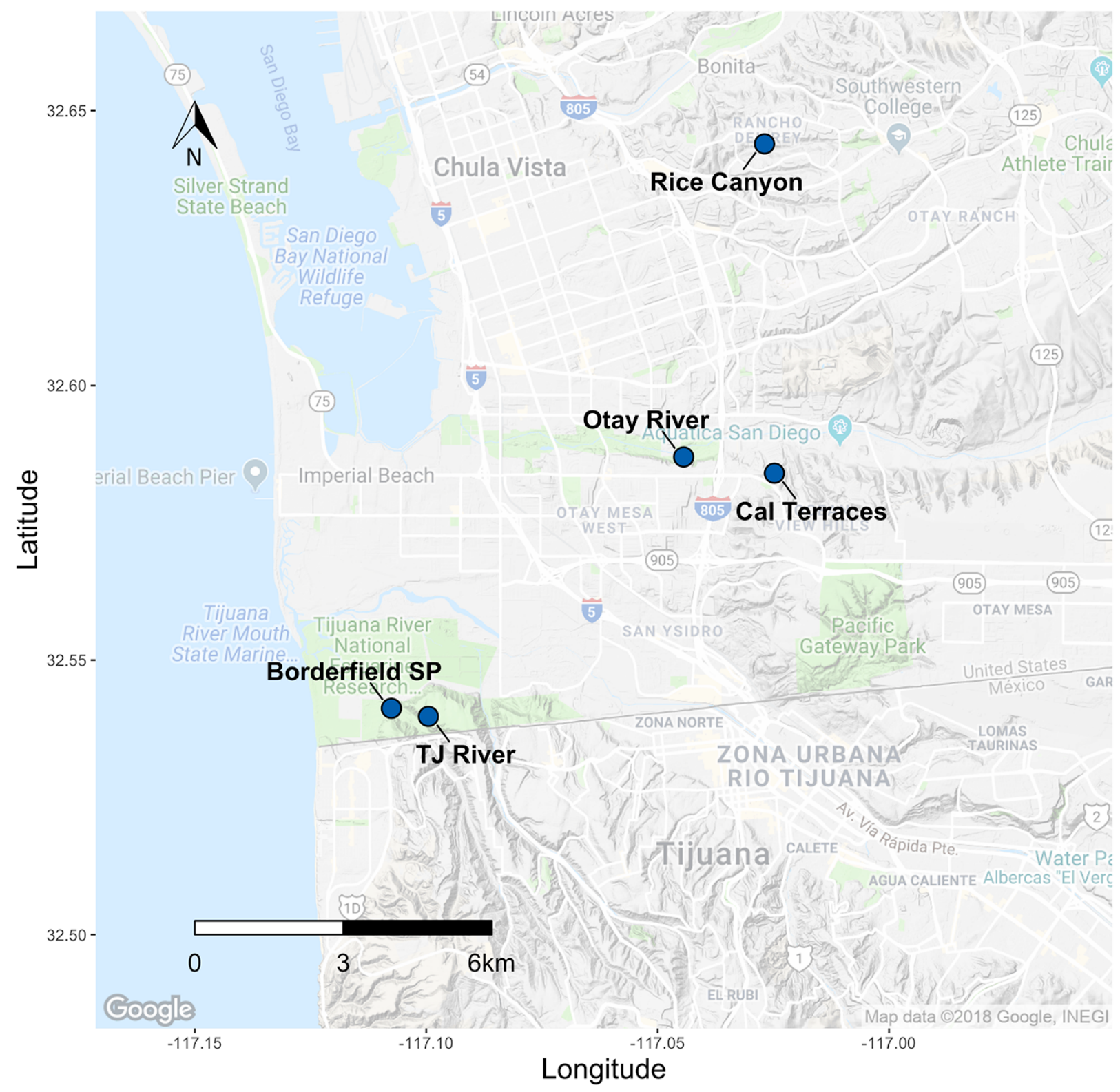

Figure 21. San Diego County map of sampled Dicranostegia orcuttiana occurrences. SP, State Park; TJ, Tijuana. 

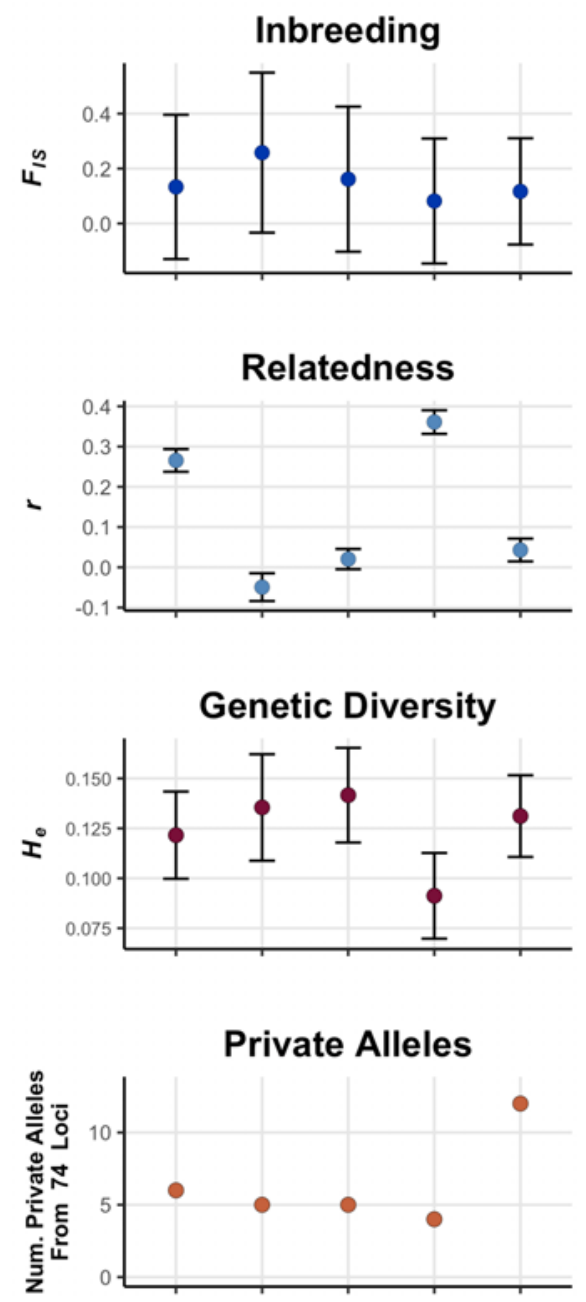

Number of Individuals Per Locus

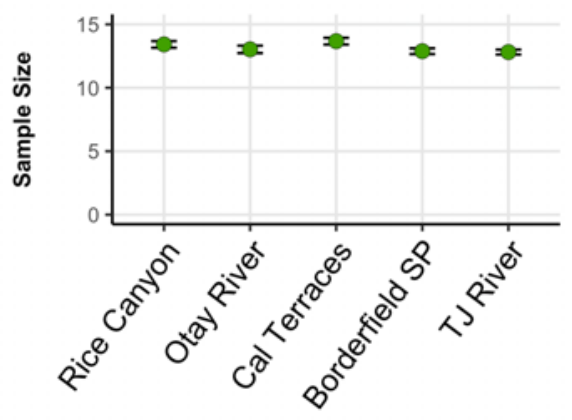

Figure 22. Genetic diversity statistics for Dicranostegia orcuttiana reported as mean values and standard errors for each occurrence. Note the scale is unique to each dataset and should be considered before comparing across plots. SP, State Park; TJ, Tijuana. 


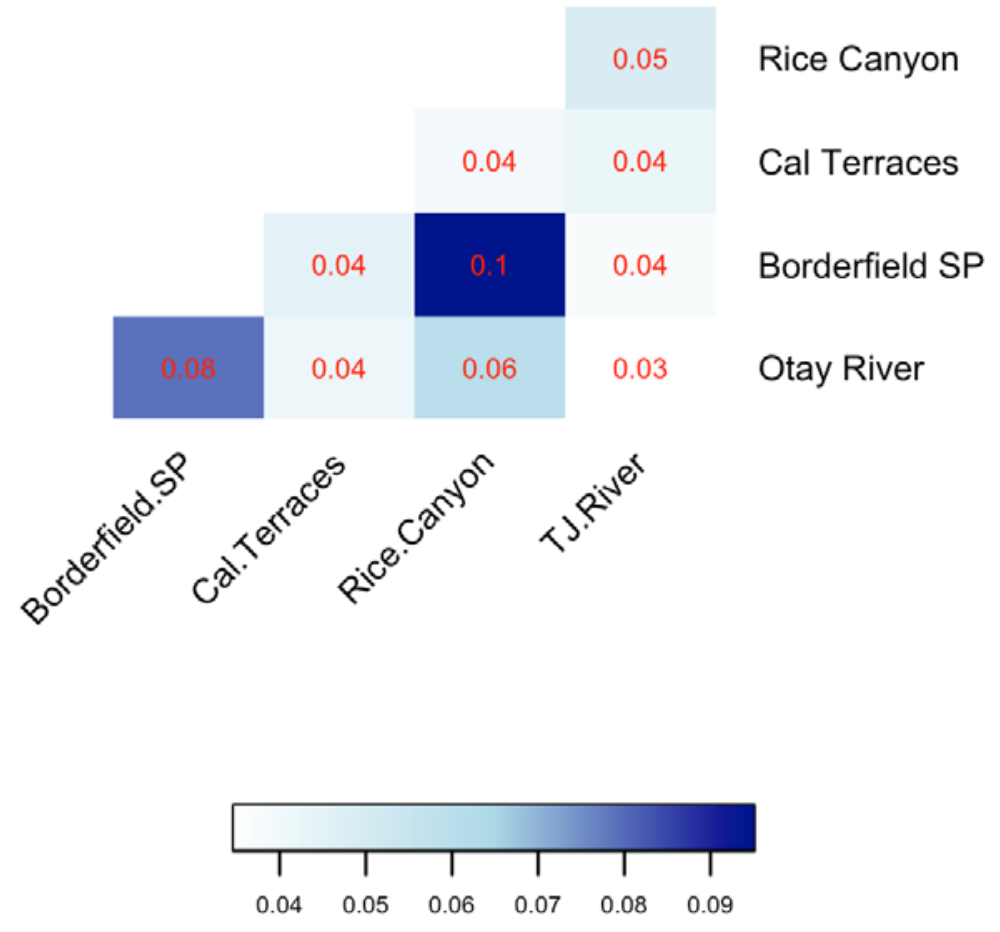

Figure 23. Pairwise $F_{S T}$ (genetic differentiation) heatmap for Dicranostegia orcuttiana occurrences. Light color shading represents low genetic differentiation, and dark color shading represents high genetic differentiation; values provided in red. Note color scale is unique to each dataset and should not be compared across species. SP, State Park; TJ, Tijuana. 


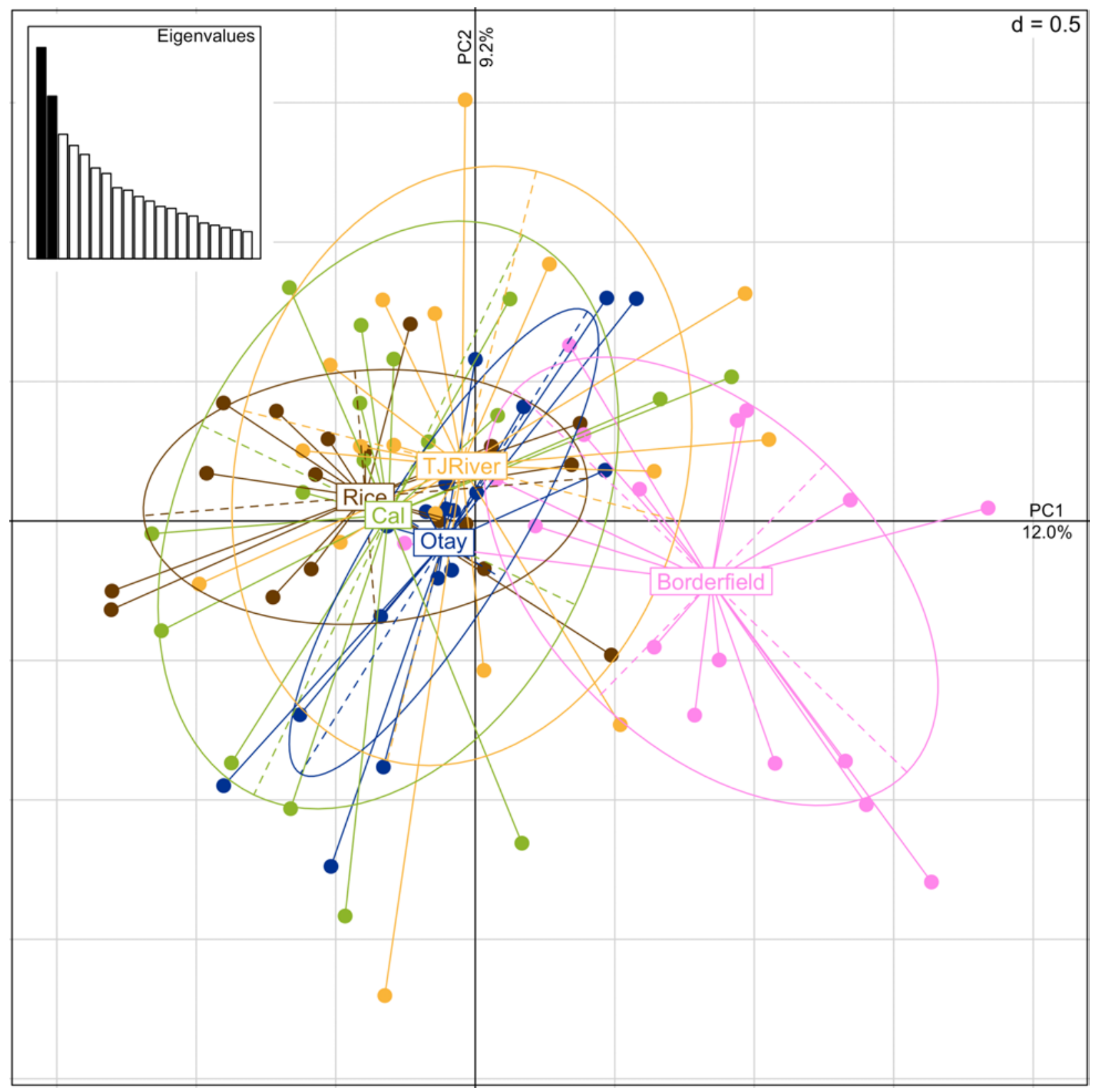

Figure 24. Principal component (PC) plot for Dicranostegia orcuttiana occurrences with PC1 on the horizontal axis and PC2 on the vertical axis. Each point represents an individual sample, and each color and ellipse represents an occurrence. Inset scree plot shows relative values of retained PCs, dimensional grid scale indicated in the upper right corner of main plot. TJ, Tijuana. 


\section{Monardella viminea}

Monardella viminea (Lamiaceae) is an herbaceous perennial endemic to the central foothills of San Diego County. It is restricted to coastal rocky drainages with most of the populations on Marine Corps Air Station (MCAS) Miramar. Monardella viminea has experienced a large and recent contraction of extant sites (U.S. Fish and Wildlife Service, 2008). This is partially due to recognition of M. stoneana as a distinct species (Elvin and Sanders, 2003; Prince, 2009), thereby reclassifying southern occurrences of $M$. viminea, and threats include changes in precipitation and hydrologic processes, mining, and urban development. As a conservation measure to offset impacts associated with development, $M$. viminea was transplanted to four sites within its historical range. Transplanted sites are in Carroll, Flanders, and San Clemente Canyons, and plants at these four sites have had low survival (San Diego Management and Monitoring Program, 2018b). In an effort to mitigate the effects of watershed damage caused by urban runoff (White and Greer, 2002), Lopez Canyon was also the site of a restoration effort where erosion control devices were installed in the canyon to preserve the alluvial terraces that support $M$. viminea (Greer and Cheong, 2005).

We analyzed 158 individuals from 12 occurrences, 6 of which are located on MCAS Miramar (fig. 25; table 2-6). Raw 100-bp paired-end sequence reads totaled 357,753,522 with an average of 2,264,262.8 (standard deviation $=1,613,905.07$ ) paired-end reads per individual. The final dataset consists of 106 independent SNP loci, using the following stacks parameters: $M=3$, $\mathrm{n}=3, \mathrm{r}=0.8, \mathrm{p}=8$. We found inbreeding to be low and consistent across sites, whereas relatedness ranged from -0.01 ( $\pm 0.03 \mathrm{SE}$ ) to 0.37 ( $\pm 0.04 \mathrm{SE}$ ) with the majority of sites falling between 0.0 and 0.2 . Genetic diversity $\left(H_{e}\right)$ ranged from 0.1 ( $\left.\pm 0.03 \mathrm{SE}\right)$ in Spring Canyon to 0.18 ( $\pm 0.02 \mathrm{SE}$ ) at the Miramar site in San Clemente Canyon (fig. 26; table 2-6). Differentiation $\left(F_{S T}\right)$ between sites was low and ranged from 0.019 to 0.091 (fig. 27). We did not find any distinct genetic clusters or evidence of isolation by distance (fig. 28).

There were no plants to sample from Carroll Canyon, but we did sample from San Clemente Canyon and Flanders Canyon. Interestingly, the occurrences closest to these transplant sites had relatively high genetic diversity and the lowest relatedness values out of all sampled locations. However, owing to the recent timing and unknown geographic details of the translocations, we cannot attribute this pattern specifically to the translocation effort. Lopez Canyon only supported seven plants, but we did not observe any loss of genetic diversity compared to the overall region. 


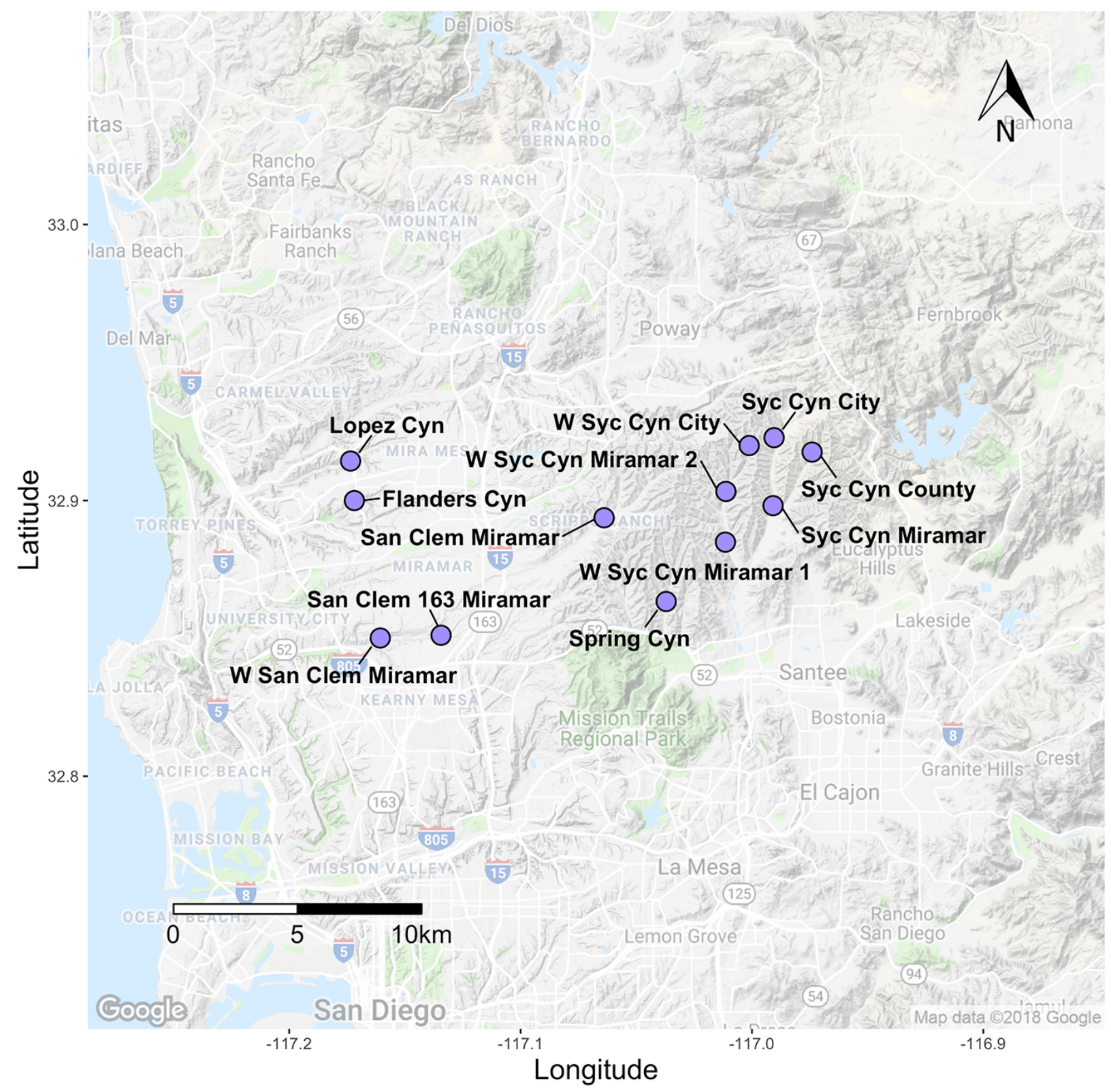

Figure 25. San Diego County map of sampled Monardella viminea occurrences. Clem, Clemente; Cyn, Canyon; MCAS, Marine Corps Air Station Miramar; Syc, Sycamore; W, West. 
Inbreeding

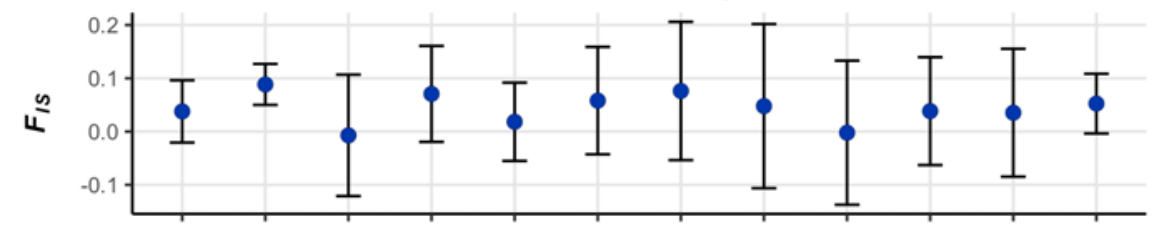

\section{Relatedness}

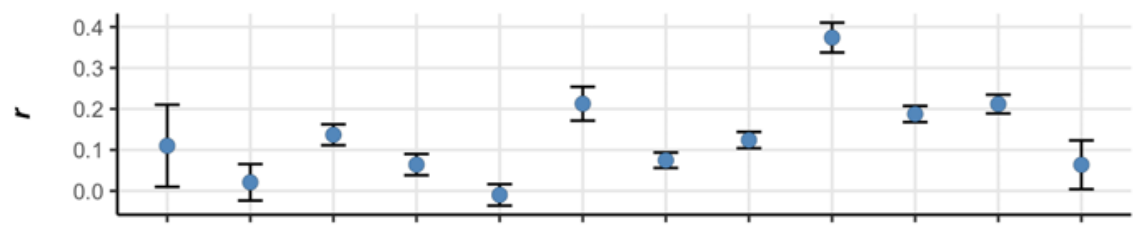

Genetic Diversity
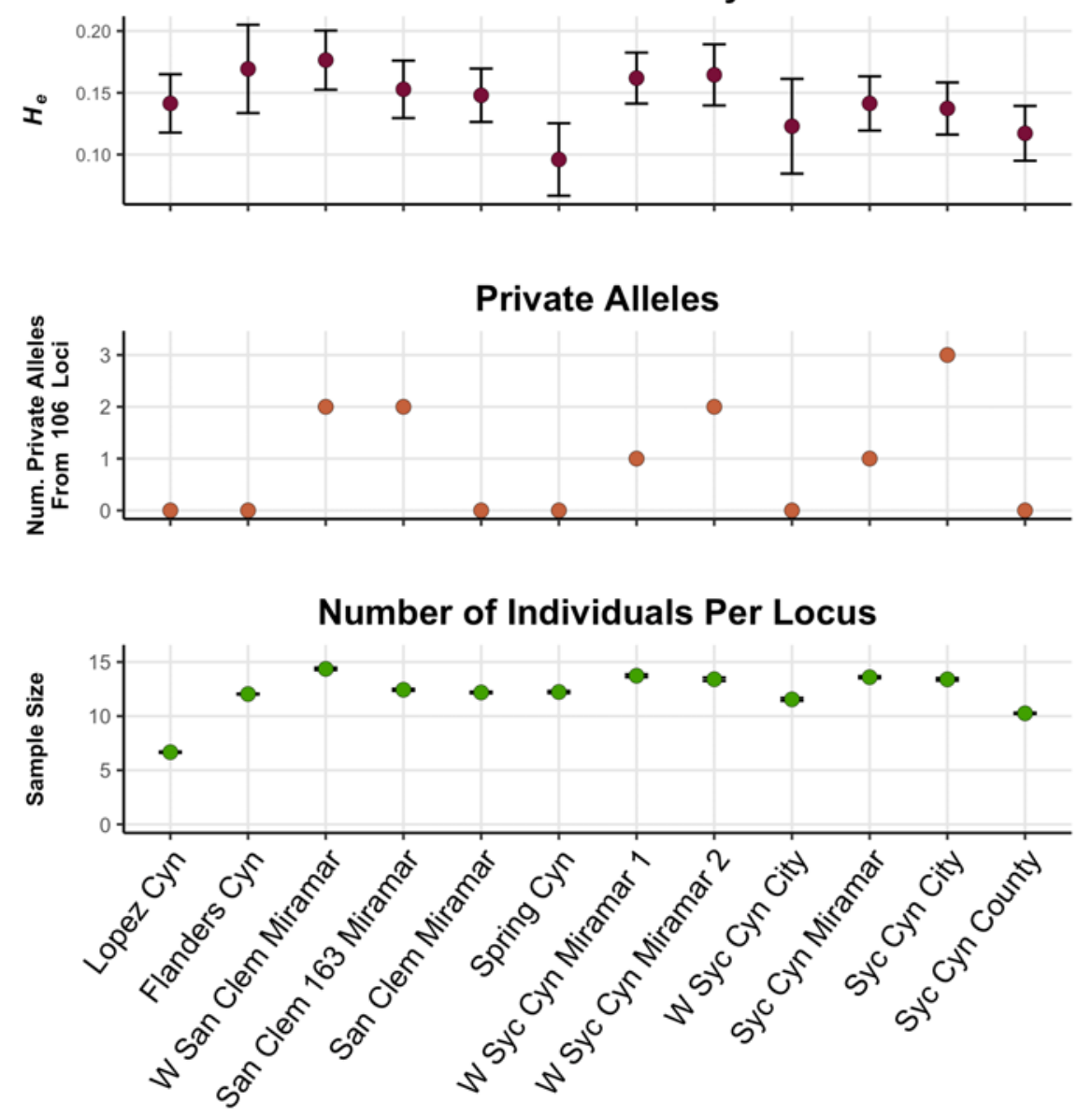

Figure 26. Genetic diversity statistics for Monardella viminea reported as mean values and standard errors for each occurrence. Note the scale is unique to each dataset and should be considered before comparing across plots. Clem, Clemente; Cyn, Canyon; MCAS, Marine Corps Air Station Miramar; Syc, Sycamore; W, West. 


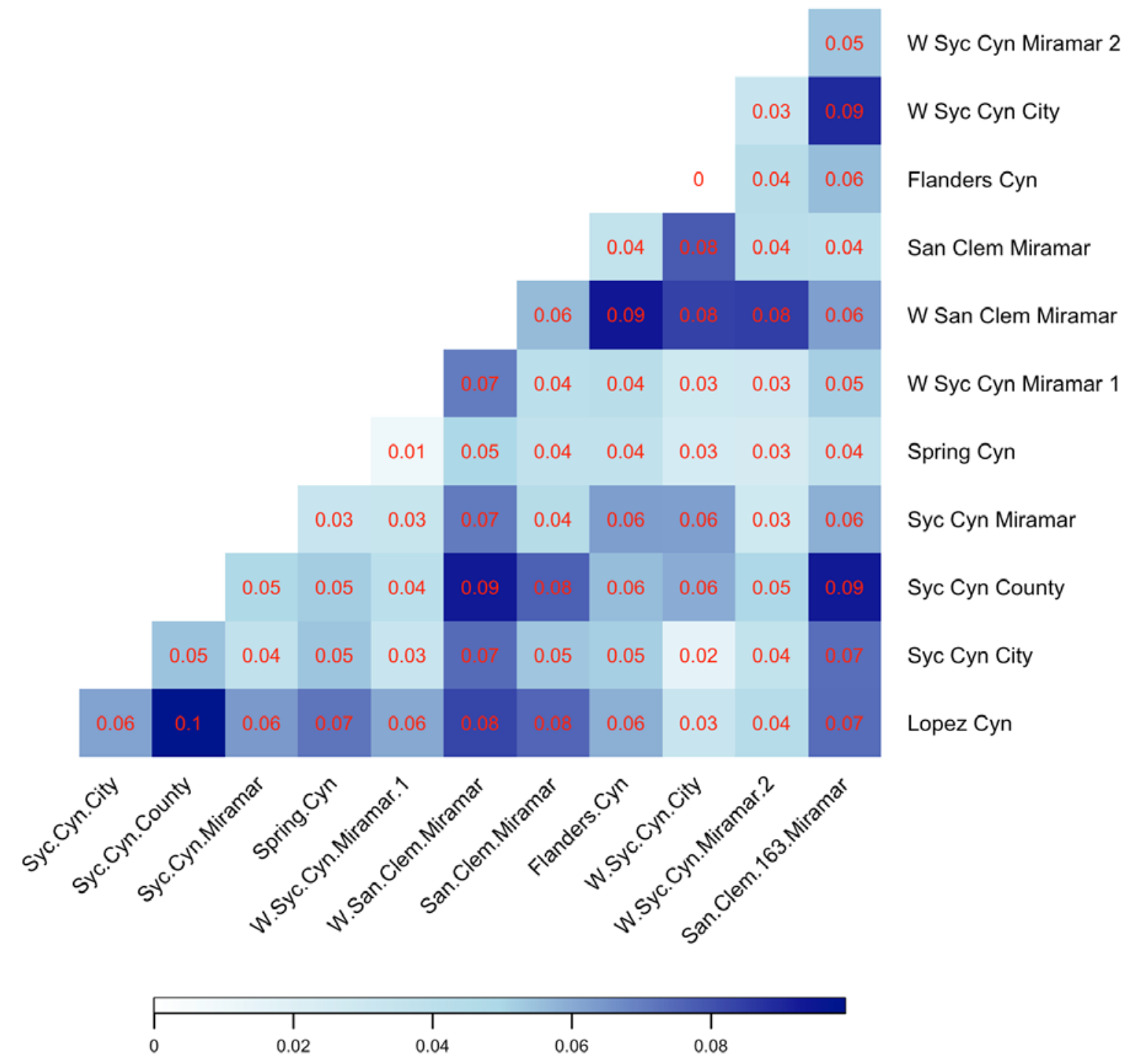

Figure 27. Pairwise $F_{S T}$ (genetic differentiation) heatmap for Monardella viminea occurrences. Light color shading represents low genetic differentiation, and dark color shading represents high genetic differentiation; values provided in red. Note color scale is unique to each dataset and should not be compared across species. Clem, Clemente; Cyn, Canyon; MCAS, Marine Corps Air Station Miramar; Syc, Sycamore; W, West. 


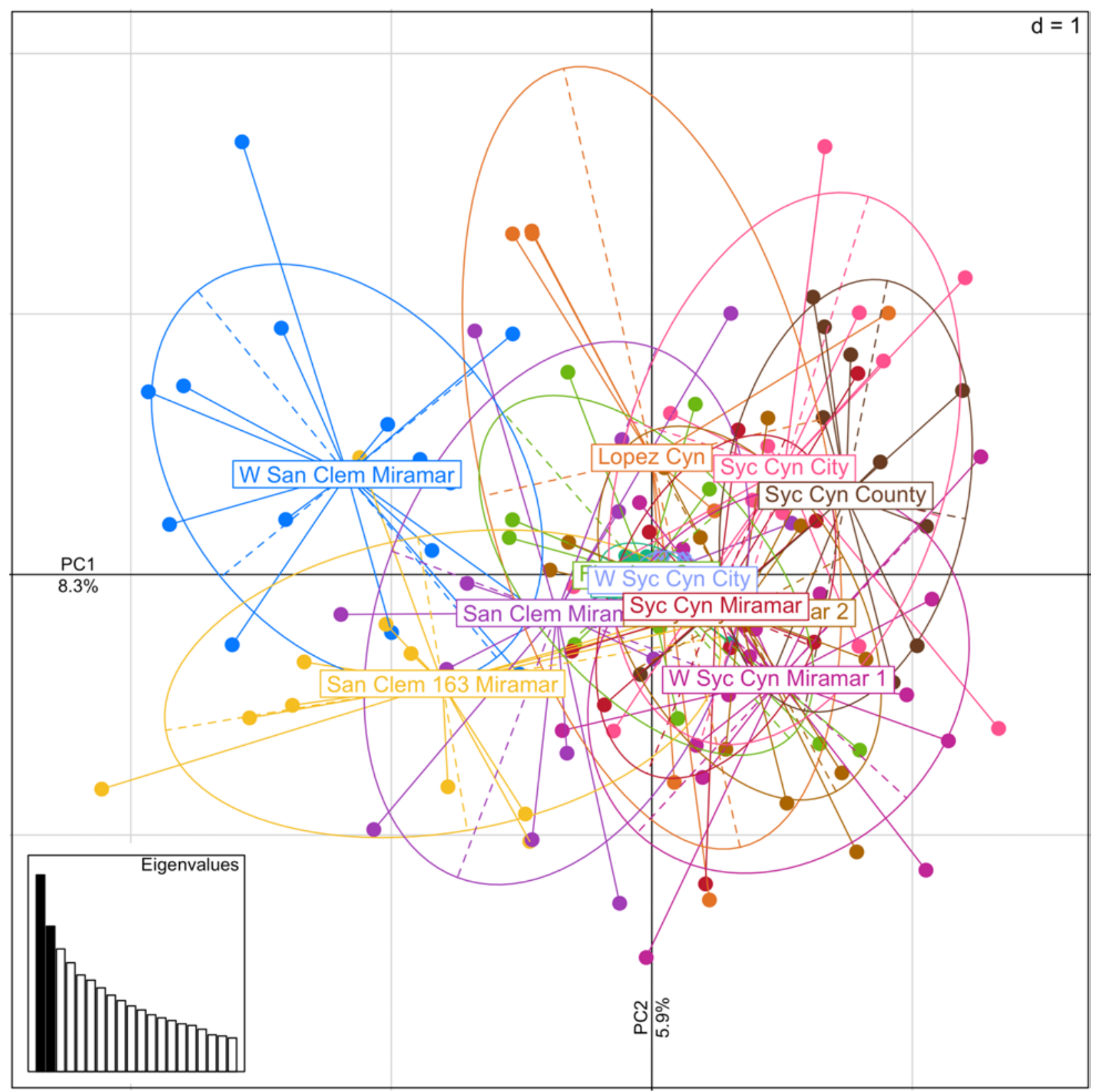

Figure 28. Principal component (PC) plot for Monardella viminea occurrences with PC1 on the horizontal axis and PC2 on the vertical axis. Each point represents an individual sample, and each color and ellipse represents an occurrence. Inset scree plot shows relative values of retained PCs, dimensional grid scale indicated in the upper right corner of main plot. Clem, Clemente; Cyn, Canyon; MCAS, Marine Corps Air Station Miramar; Syc, Sycamore; W, West. 


\section{Management Rankings and Compatible Management Strategies}

The workshop discussion and ranking results for each species are detailed in appendix 2, table 2-7. Four of the six species, $B$. vanessae, D. conjugens, D. orcuttiana, and $M$. viminea, received a management rank of 1 (low divergence, high diversity, low inbreeding). This ranking is indicative of species with high gene flow or a source/sink metapopulation structure and large effective population size. There is little indication of a loss of diversity or increased inbreeding, and there is high redundancy in genetic diversity among occurrences. Compatible management strategies could include efforts to retain gene flow among occurrences and site management to retain or increase population size in situ. Potential source sites for seed banking appear to be relatively equal based on the surveyed genetic variation alone.

Chloropyron maritimum ssp. maritimum received a management rank of 3 (low divergence, low diversity, low inbreeding). This category can indicate sparsely distributed species and populations that were historically connected but have low effective population size and (or) signature of historical bottleneck. Chloropyron maritimum ssp. maritimum has limited occurrences in San Diego, and some are restored sites with lower diversity than others. Management actions compatible with this category could include site specific restoration to increase local population size and introduction of seed sourced from higher diversity sites from within San Diego. Because C. maritimum ssp. maritimum has a disjunct distribution throughout the species range and known occurrences are genetically divergent, indicative of longer term isolation, introducing seed from other populations outside of San Diego County could have negative consequences for retaining historical diversity patterns.

The final species we examined, A. ilicifolia, received a management rank of 7-8 (high divergence, low diversity, low or mixed inbreeding). This ranking characterizes species with disjunct distributions and small or sparse population size. The finding of significant isolation by distance and spatially distinct clustering indicates that gene flow may have been a stepping stone pattern in the past (but with limitations). Current fragmentation and disturbance may increase inbreeding and extinction threat in this species. In A. ilicifolia, consistently small occurrences in the northern and eastern extents of the range appear to have particularly low genetic diversity and may warrant restoration efforts including seed bulking from within sites and introduction of additional seed. However, to retain compatibility with local genotypes, seed should be sourced from closest geographic and largest sites. Common garden experiments may help to determine whether there is strong selection against mixing among occurrences, or if mixing could increase fitness in low diversity occurrences. Previous research found signatures of mixed ploidy (2x and $4 \mathrm{x})$ in one or more north county sites and possible indication of mixed ploidy $(2 \mathrm{x}-6 \mathrm{x})$ in one or more sites at the eastern range edge (DeWoody and others, 2018). Although flow cytometry experiments performed as part of this study indicated a single ploidy level, the previously reported results may warrant caution in mixing seed sources among San Diego occurrences.

Low management rankings for most of the species we examined are a positive finding in the sense that they allow for a wide array of management options that would be compatible with genetic structure for most species and indicate that the target species retain large effective population sizes and (or) genetic connectivity. In all cases, consistent field monitoring using the IMG should be implemented to track the size and threats of focal occurrences. For a few species, notably $B$. vanessae and $D$. orcuttiana, additional efforts to locate occurrences throughout the MPA for this genetic survey resulted in newly recorded occurrences. In some cases, the panel noted that there are information gaps about breeding structure, pollen and seed dispersal, and within-site recruitment. A common theme across all species, except $M$. viminea, is that their 
distributions include at least some occurrences in Baja California, Mexico. These occurrences are not managed as part of the MPA, and little information is known about their status. Gathering comparable genetic data for populations outside of the MPA could provide additional reference populations for comparing diversity and inbreeding levels and could provide additional source materials for future restoration efforts of San Diego occurrences, particularly if assisted migration from lower latitudes is deemed an important strategy to increase climate change resilience.

In conclusion, reviewing field and genetic data with a panel of plant geneticists, ecologists, and conservation experts provided an opportunity to synthesize our results with multiple, independently conducted, published and unpublished studies and field experiences. Results from the workshop represent a comprehensive synthesis of the state of knowledge for these species and offer a model for future synthesis efforts. Furthermore, the genetic-based management rankings described here provide an accessible way to summarize genetic results across species, and across future genetic monitoring efforts, to detect and track changes meaningful for conservation and focus appropriate management efforts on each species.

\section{References Cited}

Allendorf, F.W., 1986, Genetic drift and the loss of alleles versus heterozygosity: Zoo Biology, v. 5, no. 2, p. 181-190.

Bauder, E.T., and Truesdale, D., 2000, A comparison of Hemizonia conjugens (Otay tarplant) with two closely related tarplant species using enzyme electrophoresis and soil tectural analysis: California Department of Fish and Game, Region 5 FG 7186 ES, accessed at https://nrm.dfg.ca.gov/FileHandler.ashx?DocumentID=3108.

Beauchamp, R.M., 1980, Baccharis vanessae, a new species from San Diego County, California: Phytologia, v. 46, p. 216-222.

Beugin, M.-P., Gayet, T., Pontier, D., Devillard, S., and Jombart, T., 2018, A fast likelihood solution to the genetic clustering problem: Methods in Ecology and Evolution, v. 9, no. 4, p. 1006-1016.

Catchen, J.M., Amores, A., Hohenlohe, P., Cresko, W., and Postlethwait, J.H., 2011, Stacks: building and genotyping loci de novo from short-read sequences: G3 (Bethesda), v. 1, p. 171182.

Catchen, J.M., Hohenlohe, P.A., Bassham, S., Amores, A., and Cresko, W.A., 2013, Stacks: an analysis tool set for population genomics: Molecular Ecology, v. 22, no. 11, p. 3124-3140.

Conservation Biology Institute, 2018, Enhancing the resilience of edaphic endemic plants: California Department of Fish and Wildlife Natural Community Conservation Planning Local Assistance Grant P1582108-01, accessed June 7, 2018, at https://d2k78bk4kdhbpr.cloudfront.net/media/reports/files/CBI_LAG_P1582108-

01_Final_Report__Appendices.pdf.

California Natural Diversity Database, 2011, Data use guidelines, v4: California Department of Fish and Wildlife, accessed at http://www.dfg.ca.gov/biogeodata/cnddb/.

Crnokrak, P., and Roff, D.A., 1999, Inbreeding depression in the wild: Heredity, v. 83, no. 3, p. 260.

DeWoody, J., Rogers, D.L., Hipkins, V.D., and Endress, B.A., 2018, Spatially explicit and multisourced genetic information is critical for conservation of an endangered plant species, San Diego thornmint (Acanthomintha ilicifolia): Conservation Genetics, v. 19, no. 4, p. 893-907, doi:10.1007/s10592-018-1062- y. 
Ellstrand, N.C., and Elam, D.R., 1993, Population genetic consequences of small population size: implications for plant conservation: Annual review of Ecology and Systematics, v. 24, p. 217-242.

Elvin, M.A., and Sanders, A.C., 2003, A new species of Monardella (Lamiaceae) from Baja California, Mexico, and southern California, United States: Novon, v. 13, p. 425-432.

Engelhardt, K.A.M., Lloyd, M.W., and Neel, M.C., 2014, Effects of genetic diversity on conservation and restoration potential at individual, population, and regional scales: Biological Conservation, v. 179, p. 6-16.

Frankham, R., 2005, Genetics and extinction: Biological Conservation, v. 126, no. 2, p. 131-140.

Frankham, R., Ballou, J.D., and Briscoe, D.A., 2002, Introduction to Conservation Genetics:

Cambridge, U.K., Cambridge University Press, 644 p.

Frankham, R., Ballou, J.D., Ralls, K., Eldridge, M.D.B., Dubash, M.R., Fenster, C.B., Lacy, R.C., and Sunnucks, P., 2017, Genetic management of fragmented animal and plant populations: Oxford, U.K., Oxford University Press, 401 p.

Gibson, A.L., Fishman, L., and Nelson, C.R., 2017, Polyploidy: a missing link in the conversation about seed transfer of a commonly seeded native grass in western North America: Restoration Ecology, v. 25, no. 2, p. 184-190.

Greer, K.A., and Cheong, H., 2005, Saving a rare plant in an urban environment: Fremontia, v. 33, no. 1, p. 18-22.

Hamrick, J.L., and Godt, M.J.W., 1996, Effects of life history traits on genetic diversity in plant species: Philosophical Transactions of the Royal Society B, Biological Sciences, v. 351, no. 1345, p. 1291-1298.

Harrisson, K.A., Pavlova, A., Telonis-Scott, M., and Sunnucks, P., 2014, Using genomics to characterize evolutionary potential for conservation of wild populations: Evolutionary Applications, v. 7, no. 9, p. 1008-1025.

Hartl, D.L., and Clark, A.G., 1989, Principles of population genetics: Sunderland, Mass., Sinauer Associates, $682 \mathrm{p}$.

Hohenlohe, P.A., Bassham, S., Etter, P.D., Stiffler, N., Johnson, E.A., and Cresko, W.A., 2010, Population genomics of parallel adaptation in threespine stickleback using sequenced RAD tags: PLoS Genet, v. 6, p. e1000862.

Hopkins, D.R., and Parker, V.T., 1984, A study of the seed bank of a salt marsh in $\mathrm{n}$ orthern San Francisco: American Journal of Botany, v. 71, no. 3, p. 348-355.

Hughes, A.R., Inouye, B.D., Johnson, M.T.J., Underwood, N., and Vellend, M., 2008, Ecological consequences of genetic diversity: Ecology Letters, v. 11, no. 6, p. 609-623.

Jombart, T., 2008, adegenet: a R package for the multivariate analysis of genetic markers: Bioinformatics, v. 24, no. 11, p. 1403-1405.

Markert, J.A., Champlin, D.M., Gutjahr-Gobell, R., Grear, J.S., Kuhn, A., McGreevy, T.J., Roth, A., Bagley, M.J., and Nacci, D.E., 2010, Population genetic diversity and fitness in multiple environments: BMC Evolutionary Biology, v. 10, p. 205.

McKay, J.K., Christian, C.E., Harrison, S., and Rice, K.J., 2005, “How Local is local?”-A review of practical and conceptual issues in the genetics of restoration: Restoration Ecology, v. 13, no. 3, p. 432-440.

Ottewell, K.M., Bickerton, D.C., Byrne, M., Lowe, A.J., and Burridge, C., 2016, Bridging the gap: a genetic assessment framework for population-level threatened plant conservation prioritization and decision-making: Diversity and Distributions, v. 22, p. 174-188. 
Paris, J.R., Stevens, J.R., Catchen, J.M., and Johnston, S., 2017, Lost in parameter space: a road map for stacks: Methods in Ecology and Evolution, v. 8, p. 1360-1373.

Pemberton, J., 2004, Measuring inbreeding depression in the wild: the old ways are the best: Trends in Ecology \& Evolution, v. 19, no. 12, p. 613-615.

Peterson, B.K., Weber, J.N., Kay, E.H., Fisher, H.S., and Hoekstra, H.E., 2012, Double digest RADseq: an inexpensive method for de novo SNP discovery and genotyping in model and non-model species: PLoS One, v. 7, p. e37135.

Pew, J., Muir, P.H., Wang, J., and Frasier, T.R., 2015, related: an R package for analysing pairwise relatedness from codominant molecular markers: Molecular Ecology Resources, v. 15, no. 3, p. 557-561.

Prince, L.M., 2009, The relationship of Monardella viminea to closely related taxa based on analysis of ISSRs: California Department of Fish and Wildlife web page, Prepared for the U.S. Fish and Wildlife Service, Final Report P0750003, accessed at https://nrm.dfg.ca.gov/FileHandler.ashx?DocumentID=24524.

Queller, D.C., and Goodnight, K.F., 1989, Estimating relatedness using genetic markers: Evolution, v. 43, no. 2, p. 258-275.

R Core Team, 2016, R: A language and environment for statistical computing (ver. 3.2.2): R Project for Statistical Computing, accessed September 2016 at https://www.R-project.org/.

Rochette, N.C., and Catchen, J.M., 2017, Deriving genotypes from RAD-seq short-read data using Stacks: Nature Protocols, v. 12, p. 2640-2659.

San Diego Management and Monitoring Program, 2018a, Rare plant inspect and manage monitoring 2014-2018: San Diego Management and Monitoring Program Projects, accessed at https://sdmmp.com/view_project.php?sdid=SDID_sarah.mccutcheon\%40aecom.com_57cf019 6 dff76.

San Diego Management and Monitoring Program, 2018b, Species profile: Willowy monardella: San Diego Management and Monitoring Program web page, accessed June 7, 2018, at https://sdmmp.com/species_profile.php?taxaid=833060.

San Diego Management and Monitoring Program and The Nature Conservancy, 2017, Management and monitoring strategic plan for conserved lands in western San Diego County: A strategic habitat conservation roadmap:San Diego Management and Monitoring Program web page, Prepared for San Diego Association of Governments, accessed May 24, 2018, at https://sdmmp.com/msp_doc.php.

San Diego Natural History Museum, 2018, A report of genetic sample collections and curation for six rare plants within the San Diego MSPA San Diego County, California: San Diego Management and Monitoring Program web page, Prepared for San Diego Association of Governments, accessed at https://sdmmp.com/upload/SDMMP_Repository/0/s1n8zbqxdtr329wvy7k456mp00ghfj.pdf. Slatkin, M., 1987, Gene flow and the geographic structure of natural populations: Science, v. 236, no. 4803, p. 787-792.

Spielman, D., Brook, B.W., Briscoe, D.A., and Frankham, R., 2004, Does inbreeding and loss of genetic diversity decrease disease resistance?: Conservation Genetics, v. 5, no. 4, p. 439-448.

U.S. Fish and Wildlife Service, 2008, Monardella linoides subsp. viminea (Willowy Monardella), 5-year review: Summary and evaluation: U.S. Fish and Wildlife Service web page, accessed May 2, 2018, at https://ecos.fws.gov/docs/five_year_review/doc1904.pdf.

U.S. Fish and Wildlife Service, S.D., 2009a, Acanthomintha ilicifolia (San Diego thornmint), 5year review: Summary and evaluation: U.S. Fish and Wildlife Service, 39 p. 
U.S. Fish and Wildlife Service, S.D., 2009b, Chloropyron maritimum subsp. maritimum (Cordylanthus maritimus subsp. maritimus) (salt marsh bird’s-beak), 5-year review: Summary and evaluation: U.S. Fish and Wildlife Service web page, accessed June 15, 2018, at https://www.fws.gov/carlsbad/SpeciesStatusList/5YR/20090813_5YR_CHMAMA.pdf.

U.S. Fish and Wildlife Service, 2009c, Deinandra conjugens (Otay tarplant), 5-year review: Summary and evaluation: U.S. Fish and Wildlife Service web page, accessed June 5, 2018, at https://ecos.fws.gov/docs/five_year_review/doc2632.pdf.

U.S. Fish and Wildlife Service, 2011, Baccharis vanessae (Encinitas baccharis), 5-year review: Summary and evaluation: U.S. Fish and Wildlife Service web page, accessed at https://www.fws.gov/carlsbad/SpeciesStatusList/5YR/20111222_5YR_BAVA.pdf.

Walker, B.H., 1992, Biodiversity and ecological redundancy: Conservation Biology, v. 6, no. 1, p. 18-23.

Wang, J., 2007, Triadic IBD coefficients and applications to estimating pairwise relatedness: Genetics Research, v. 89, no. 3, p. 135-153.

Wang, J., 2017, Estimating pairwise relatedness in a small sample of individuals: Heredity, v. 119, no. 5, p. 302.

Weeks, A.R., Sgro, C.M., Young, A.G., Frankham, R., Mitchell, N.J., Miller, K.A., Byrne, M., Coates, D.J., Eldridge, M.D.B., Sunnucks, P., Breed, M.F., James, E.A., and Hoffmann, A.A., 2011, Assessing the benefits and risks of translocations in changing environments: a genetic perspective: Evolutionary Applications, v. 4, no. 6, p. 709-725.

Weir, B.S., 1996, Genetic data snalysis II: Methods for discrete population genetic data: Sinauer Associates, University of Michigan, 445 p.

White, M.D., and Greer, K.A., 2002, The effects of watershed urbanization on stream hydrologic characteristics and riparian vegetation of Los Peñasquitos Creek, California: Conservation Biology Institute, accessed June 7, 2018, at https://d2k78bk4kdhbpr.cloudfront.net/media/reports/files/penasquitos.pdf.

Williams, S.L., 2001, Reduced genetic diversity in eelgrass transplantations affects both population growth and individual fitness: Ecological Applications, v. 11, no. 5, p. 1472-1488.

Wright, S., 1931, Evolution in Mendelian populations: Genetics, v. 16, p. 97-159.

Wright, S., 1938, Size of population and breeding structure in relation to evolution: Science, v. 87, p. 430-431.

Wright, S., 1978, Evolution and the genetics of populations, volume 4: Chicago, Ill., University of Chicago Press, 590 p.

Young, A., Boyle, T., and Brown, T., 1996, The population genetic consequences of habitat fragmentation for plants: Trends in Ecology \& Evolution, v. 11, no. 10, p. 413-418.

\section{Glossary}

Some definitions adapted from National Human Genome Research Institute Talking Glossary of Genetic Terms at https://www.genome.gov/glossary/, Hartl and Clark (1989), and Frankham and others (2017).

Adaptive Referring to a genotype or trait; conferring high relative fitness to individuals possessing it.

Allele One particular form of a gene (diploid organisms have two of each). 
Assisted migration The managed movement of individuals into populations to increase genetic variation and relative fitness.

Base pair A single "position” (or single nucleic acid) on a strand of DNA containing an adenine, cytosine, guanine, or thymine nucleobase. Nuclear DNA is double stranded with complimentary bases or base pairs (guanine-cytosine and adenine-thymine) that allow the DNA helix to maintain a regular helical structure.

C-value The amount, in picograms, of DNA contained within a haploid nucleus.

DNA extraction Process of purifying genomic DNA from a tissue or other sample. Most processes include both physical and chemical extraction steps.

Fitness The net effect of viability, mating success, and fecundity that determines number of progeny.

Gene flow The movement of genes among populations connected by dispersal and migration. The incorporation of "migrant" genes into a population requires both successful immigration and successful interbreeding.

Genetic bottleneck A sharp reduction in the size of a population. Also called a population bottleneck.

Genetic differentiation A process in which two or more populations accumulate independent genetic changes (DNA sequence mutations) or allele frequency differences through time as a result of reduced gene flow or complete reproductive isolation for some period of time. Estimators of genetic differentiation include Wright's fixation index $\left(F_{S T}\right)$ and Weir \& Cockerham's index $(\theta)$. Also called genetic divergence.

Genetic diversity The existing genetic variation within a population or species. Various measures are used to estimate genetic diversity such as determining the number of polymorphic sites across a specified region of DNA sequence or determining the number of heterozygous individuals in a population. Some commonly used genetic diversity measures include polymorphic sites(s), heterozygosity $(H)$, and nucleotide diversity (pi).

Genetic drift The change in allele frequencies over time due to the chance disappearance of particular alleles as individuals die or do not reproduce. Drift is stronger in smaller populations and leads to greater genetic differentiation among populations and lower diversity within them.

Genetic marker See locus.

Genetic structure The distribution of genotypes within and among populations.

Genotype A genetic profile indicating the particular alleles present at one or more loci within an organism.

Halophyte A plant adapted to grow in saline conditions, as in a salt marsh.

Hemiparasite A plant that obtains or may obtain part of its food by parasitism, which also photosynthesizes.

Heterozygosity A diploid organism is heterozygous at a gene locus when there are two different alleles of a gene present. Heterozygosity measures the proportion of heterozygous individuals for a locus (or set of loci) in a population.

Isolation by distance (IBD) A positive correlation between geographic distance and genetic divergence of sampling locations.

Inbreeding depression Reduced fitness of offspring as a result of mating of individuals related by descent.

Locus (plural: loci) Gene regions that are scattered throughout the genome and not physically linked. 
Local adaptation The process by which organisms in a particular locality have differentially evolved as compared to other localities in response to selective pressures imposed by some biotic or abiotic aspect of their local environment.

Outbreeding depression Reduced fitness of offspring as a result of matings between genetically divergent individuals.

Population A group of related individuals in the same geographic area that freely interbreed. Private allele An allele found in only a single population.

Restriction enzyme An enzyme that cuts DNA molecules at a specific sequence recognition site. Selection Differential survival and reproduction among individuals owing to heritable trait differences.

Sequencing The process of determining the precise order of nucleotides within a DNA molecule. Single Nucleotide Polymorphism (SNP) A single base mutation at a specific locus usually consisting of two alleles. In a diploid organism, an individual can be either homozygous for one or another allele copy, or heterozygous (containing different allele copies). Many SNPs can be combined to provide an individual genetic fingerprint or genotype.

\section{Appendix 1.}

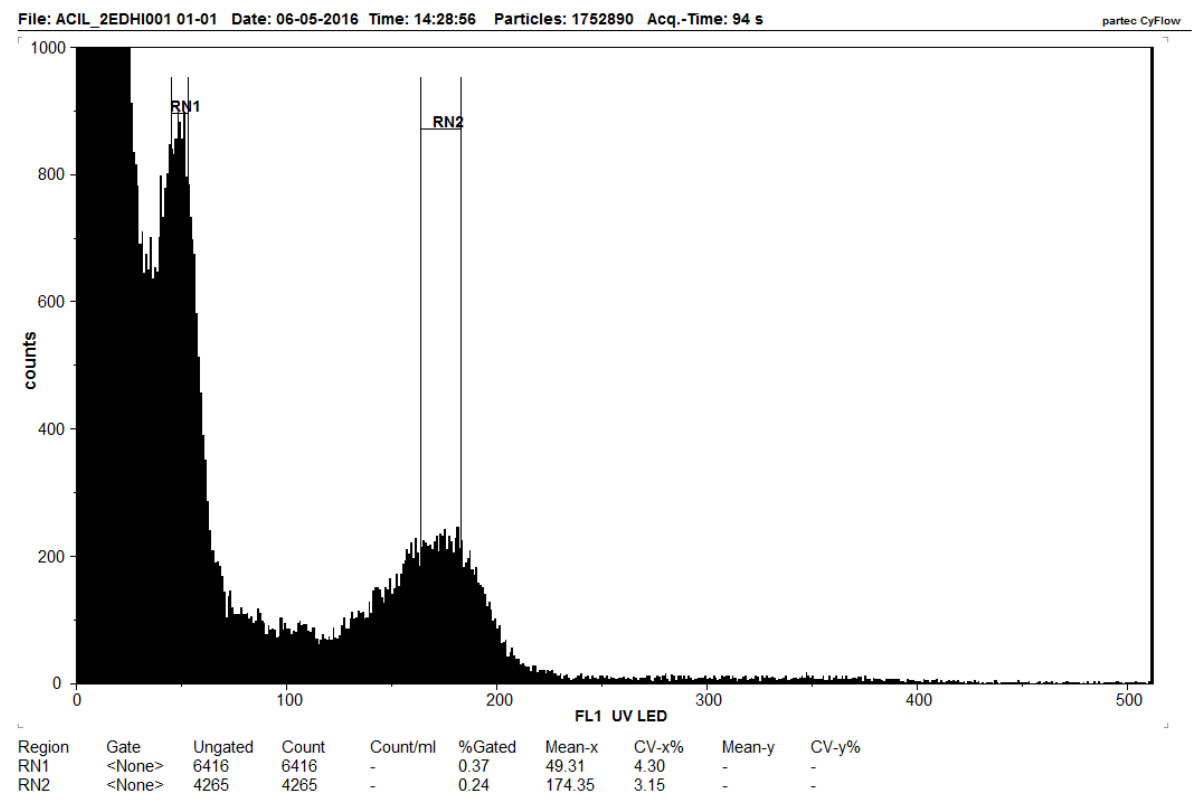

Figure 1-1. Example histogram output from flow cytometry analysis; RN1 indicates peak position of internal standard, and RN2 indicates peak position of sample. 


\section{Appendix 2.}

Table 2-1. Acanthomintha ilicifolia occurrence locations and summary statistics.

[Mtn, Mountain; Ter, Terraces; TNC, The Nature Conservancy]

\begin{tabular}{|c|c|c|c|c|c|c|c|c|c|c|c|}
\hline Occurrence & SDMMP ID & Latitude & Longitude & $F_{I S}$ & $\begin{array}{c}F_{I S} \\
\text { St. Err }\end{array}$ & $r$ & $\begin{array}{c}r \\
\text { St. Err }\end{array}$ & $H_{e}$ & $\begin{array}{c}H_{e} \\
\text { St. Err }\end{array}$ & $\begin{array}{l}\text { Private } \\
\text { alleles }\end{array}$ & $\begin{array}{c}\text { Sample } \\
\text { size }\end{array}$ \\
\hline Palomar Airport & ACIL_6PARO043 & 33.137 & -117.263 & 0.015 & 0.069 & 0.745 & 0.012 & 0.028 & 0.009 & 1 & 13.433 \\
\hline Emerald Pointe & ACIL_6EMPO037 & 33.121 & -117.299 & 0.006 & 0.063 & 0.948 & 0.008 & 0.007 & 0.003 & 0 & 12.386 \\
\hline La Costa & ACIL_6LCGR038 & 33.118 & -117.265 & 0.045 & 0.058 & 0.640 & 0.010 & 0.033 & 0.008 & 4 & 14.492 \\
\hline Lux Cyn East & ACIL_6MAMI041 & 33.032 & -117.250 & 0.020 & 0.086 & 0.802 & 0.010 & 0.019 & 0.006 & 3 & 14.751 \\
\hline Simon Preserve & ACIL_4SIPR026 & 33.026 & -116.824 & 0.027 & 0.060 & 0.523 & 0.014 & 0.048 & 0.010 & 3 & 14.582 \\
\hline Saber Springs & ACIL_4SASP025 & 32.942 & -117.092 & 0.052 & 0.045 & 0.228 & 0.032 & 0.072 & 0.013 & 2 & 8.592 \\
\hline Sycamore Canyon & ACIL_4SYCA027 & 32.935 & -116.978 & 0.087 & 0.165 & 0.218 & 0.034 & 0.074 & 0.018 & 3 & 13.550 \\
\hline Los Penasquitos & ACIL_6LPCA039 & 32.927 & -117.180 & 0.040 & 0.063 & 0.504 & 0.014 & 0.054 & 0.009 & 0 & 14.122 \\
\hline Viejas & ACIL_4VIMT0028 & 32.866 & -116.737 & 0.038 & 0.049 & 0.705 & 0.012 & 0.024 & 0.007 & 0 & 12.598 \\
\hline Viejas Southwest & ACIL_4VIMT0030 & 32.856 & -116.744 & 0.061 & 0.066 & 0.534 & 0.014 & 0.044 & 0.008 & 2 & 14.367 \\
\hline La Force Alpine & NA & 32.829 & -116.807 & 0.031 & 0.069 & 0.344 & 0.014 & 0.059 & 0.010 & 2 & 14.333 \\
\hline Mission Trails & ACIL_4MTRP021 & 32.825 & -117.074 & 0.015 & 0.071 & 0.569 & 0.013 & 0.052 & 0.010 & 1 & 14.306 \\
\hline Wrights Field & ACIL_3WRFI018 & 32.820 & -116.767 & 0.034 & 0.067 & 0.835 & 0.015 & 0.017 & 0.005 & 1 & 14.255 \\
\hline El Dorado Hills & ACIL_2EDHI001 & 32.818 & -117.084 & 0.044 & 0.067 & 0.239 & 0.014 & 0.073 & 0.011 & 0 & 14.391 \\
\hline Suncrest & ACIL_3SOCR016 & 32.788 & -116.866 & 0.018 & 0.071 & 0.370 & 0.013 & 0.067 & 0.011 & 3 & 14.291 \\
\hline McGinty Peak & ACIL_3MGMT010 & 32.752 & -116.860 & 0.041 & 0.081 & 0.320 & 0.014 & 0.062 & 0.010 & 3 & 13.943 \\
\hline McGinty TNC & ACIL_3MGMT008 & 32.750 & -116.870 & 0.025 & 0.076 & 0.320 & 0.017 & 0.063 & 0.011 & 4 & 13.940 \\
\hline McGinty Mtn & ACIL_3MGMT009 & 32.737 & -116.867 & 0.056 & 0.073 & 0.432 & 0.015 & 0.060 & 0.010 & 2 & 14.041 \\
\hline Hollenbeck & ACIL_3HCWA006 & 32.699 & -116.814 & 0.038 & 0.073 & 0.317 & 0.012 & 0.071 & 0.011 & 3 & 14.341 \\
\hline Bonita Meadows & ACIL_3BOME003 & 32.665 & -116.994 & 0.072 & 0.075 & 0.163 & 0.019 & 0.074 & 0.010 & 7 & 14.164 \\
\hline Wheeler Ridge & ACIL_3WHRI017 & 32.658 & -117.010 & 0.038 & 0.068 & 0.246 & 0.016 & 0.068 & 0.010 & 9 & 14.293 \\
\hline Long Canyon & ACIL_3LONC007 & 32.653 & -116.998 & 0.034 & 0.069 & 0.400 & 0.016 & 0.050 & 0.009 & 3 & 14.324 \\
\hline Rice Canyon & ACIL_3PMA1013 & 32.644 & -117.016 & 0.043 & 0.069 & 0.239 & 0.018 & 0.062 & 0.009 & 4 & 14.225 \\
\hline Dennery Cal Ter & ACIL_3DREA005 & 32.584 & -117.024 & 0.054 & 0.075 & 0.247 & 0.018 & 0.070 & 0.010 & 3 & 14.209 \\
\hline
\end{tabular}


Table 2-2. Baccharis vanessae occurrence locations and summary statistics.

[CPEN, Marine Corps Base Camp Pendleton; Mtn, Mountain; Pres, Preserve]

\begin{tabular}{|c|c|c|c|c|c|c|c|c|c|c|c|}
\hline Occurrence & SDMMP ID & Latitude & Longitude & $F_{I S}$ & $\begin{array}{c}F_{I S} \\
\text { St. Err }\end{array}$ & $r$ & $\begin{array}{c}r \\
\text { St. Err }\end{array}$ & $H_{e}$ & $\begin{array}{c}H_{e} \\
\text { St. Err }\end{array}$ & $\begin{array}{l}\text { Private } \\
\text { alleles } \\
\end{array}$ & $\begin{array}{c}\text { Sample } \\
\text { size }\end{array}$ \\
\hline CPEN Devils Canyon & NA & 33.471 & -117.464 & 0.000 & 0.249 & 0.489 & 0.031 & 0.038 & 0.016 & 7 & 12.919 \\
\hline CPEN Case Springs & NA & 33.454 & -117.439 & -0.012 & 0.141 & 0.481 & 0.086 & 0.048 & 0.020 & 2 & 9.167 \\
\hline Elfin Forest Reserve & BAVA3_6EFRR005 & 33.079 & -117.128 & 0.039 & 0.299 & 0.172 & 0.029 & 0.058 & 0.019 & 5 & 17.683 \\
\hline Encinitas Ranch & BAVA3_6ENRA013 & 33.067 & -117.271 & -0.032 & 0.110 & 0.510 & 0.049 & 0.056 & 0.024 & 0 & 9.690 \\
\hline Del Dios Preserve & BAVA3_6DDHP004 & 33.065 & -117.128 & 0.007 & 0.116 & 0.029 & 0.135 & 0.052 & 0.018 & 2 & 13.000 \\
\hline Escondido Creek Pres & BAVA3_6ECPR006 & 33.063 & -117.174 & -0.007 & 0.189 & 0.597 & 0.026 & 0.047 & 0.018 & 4 & 13.318 \\
\hline Oakcrest Park & BAVA3_6OAPA008 & 33.046 & -117.265 & -0.008 & 0.154 & -0.050 & 0.055 & 0.088 & 0.027 & 4 & 11.265 \\
\hline Mount Woodson South & BAVA3_4MTWO09 & 33.009 & -116.971 & 0.020 & 0.211 & 0.413 & 0.034 & 0.058 & 0.021 & 2 & 13.465 \\
\hline Iron Mtn South & BAVA3_4IRMT002 & 32.976 & -116.955 & 0.017 & 0.092 & 0.543 & 0.085 & 0.038 & 0.020 & 1 & 5.567 \\
\hline Gibson Highlands & BAVA3_3GIHI010 & 32.836 & -116.837 & 0.103 & 0.224 & 0.221 & 0.058 & 0.056 & 0.017 & 6 & 12.115 \\
\hline Otay Mtn South & BAVA3_3OTMT001 & 32.573 & -116.842 & -0.028 & 0.225 & 0.539 & 0.038 & 0.065 & 0.024 & 2 & 15.359 \\
\hline
\end{tabular}


Table 2-3. Chloropyron maritimum ssp. Maritimum occurrence locations and summary statistics.

[NB, Naval Base; Sp, Springs; TJE, Tijuana Estuary]

\begin{tabular}{|c|c|c|c|c|c|c|c|c|c|c|c|c|}
\hline Occurrence & SDMMP ID & Latitude & Longitude & $F_{I S}$ & $\begin{array}{c}F_{I S} \\
\text { St. Err }\end{array}$ & $r$ & $\begin{array}{c}r \\
\text { St. Err }\end{array}$ & $H_{e}$ & $\begin{array}{c}H_{e} \\
\text { St. Err }\end{array}$ & $\begin{array}{l}\text { Private } \\
\text { alleles }\end{array}$ & $\begin{array}{l}\text { Sample } \\
\text { size }\end{array}$ & Dataset \\
\hline Morro Bay Sandspit & NA & 35.351 & -120.859 & 0.000 & 0.177 & na & na & 0.000 & 0.000 & 0 & 13.970 & Regional \\
\hline Morro Bay Sweet Sp & NA & 35.322 & -120.845 & 0.000 & 0.256 & na & na & 0.006 & 0.004 & 1 & 12.231 & Regional \\
\hline Carpinteria East & NA & 34.398 & -119.534 & 0.038 & 0.278 & na & na & 0.023 & 0.017 & 0 & 13.719 & Regional \\
\hline Ormond Beach City & NA & 34.124 & -119.157 & 0.016 & 0.139 & na & na & 0.014 & 0.010 & 0 & 14.353 & Regional \\
\hline Pt Mugu Cotar & NA & 34.121 & -119.158 & 0.027 & 0.200 & na & na & 0.033 & 0.019 & 1 & 13.706 & Regional \\
\hline Pt Mugu Perimeter & NA & 34.121 & -119.150 & -0.004 & 0.155 & na & na & 0.019 & 0.017 & 0 & 11.967 & Regional \\
\hline Pt Mugu Mad Road & NA & 34.113 & -119.134 & -0.003 & 0.180 & na & na & 0.021 & 0.015 & 1 & 12.086 & Regional \\
\hline Pt Mugu Camera Pad & NA & 34.107 & -119.139 & 0.058 & 0.224 & na & na & 0.063 & 0.028 & 2 & 12.375 & Regional \\
\hline Pt Mugu Beach Pad & NA & 34.099 & -119.120 & 0.090 & 0.227 & na & na & 0.053 & 0.028 & 0 & 12.370 & Regional \\
\hline Upper Newport & NA & 33.621 & -117.891 & 0.076 & 0.172 & na & na & 0.075 & 0.030 & 3 & 13.344 & Regional \\
\hline Dog Beach & COMAM3_1DOBE007 & 32.755 & -117.248 & 0.030 & 0.225 & 0.028 & 0.039 & 0.048 & 0.022 & 1 & 13.750 & San Diego \\
\hline Paradise Marsh & COMAM3_1TIES005 & 32.652 & -117.106 & 0.015 & 0.168 & 0.765 & 0.054 & 0.015 & 0.012 & 1 & 11.250 & San Diego \\
\hline Sweetwater Marsh 1 & COMAM3_1SWMA005 & 32.647 & -117.104 & 0.010 & 0.158 & 0.523 & 0.035 & 0.038 & 0.017 & 2 & 11.688 & San Diego \\
\hline Sweetwater Marsh 2 & СOMAM3_1SWMA006 & 32.643 & -117.109 & 0.041 & 0.146 & 0.334 & 0.041 & 0.029 & 0.015 & 1 & 11.618 & San Diego \\
\hline NB Coronado & COMAM3_1IMBE008 & 32.604 & -117.124 & 0.019 & 0.147 & 0.278 & 0.038 & 0.030 & 0.018 & 1 & 11.970 & San Diego \\
\hline TJE Caspian Way & COMAM3_1TIES009 & 32.574 & -117.127 & -0.012 & 0.310 & -0.132 & 0.075 & 0.083 & 0.043 & 0 & 11.250 & San Diego \\
\hline TJE Seacoast North & COMAM3_1TIES010 & 32.573 & -117.132 & 0.015 & 0.242 & 0.366 & 0.068 & 0.075 & 0.055 & 0 & 11.444 & San Diego \\
\hline TJE River Mouth & COMAM3_1TIES002.1 & 32.570 & -117.128 & 0.044 & 0.202 & 0.341 & 0.076 & 0.085 & 0.039 & 0 & 8.571 & San Diego \\
\hline TJE Iris Avenue & COMAM3_1TIES002 & 32.569 & -117.124 & 0.008 & 0.150 & 0.281 & 0.053 & 0.043 & 0.023 & 1 & 10.968 & San Diego \\
\hline TJE Seacoast South & COMAM3_1TIES002.5 & 32.565 & -117.132 & 0.002 & 0.231 & 0.186 & 0.081 & 0.072 & 0.039 & 0 & 10.824 & San Diego \\
\hline Bahia Falsa & NA & 30.452 & -115.997 & 0.017 & 0.236 & na & na & 0.027 & 0.016 & 4 & 13.219 & Regional \\
\hline Punta Azufre & NA & 30.422 & -115.942 & -0.002 & 0.299 & na & na & 0.053 & 0.034 & 0 & 13.000 & Regional \\
\hline
\end{tabular}


Table 2-4. Deinandra conjugens occurrence locations and summary statistics.

[E, East; SDNWR, San Diego National Wildlife Refuge; VP, Vernal Pool]

\begin{tabular}{|c|c|c|c|c|c|c|c|c|c|c|c|}
\hline Occurrence & SDMMP ID & Latitude & Longitude & $F_{I S}$ & $\begin{array}{c}\text { F/S } \\
\text { St. Err }\end{array}$ & $r$ & $\begin{array}{c}r \\
\text { St. Err }\end{array}$ & $H_{e}$ & $\begin{array}{c}H_{e} \\
\text { St. Err }\end{array}$ & $\begin{array}{l}\text { Private } \\
\text { alleles }\end{array}$ & $\begin{array}{c}\text { Sample } \\
\text { size }\end{array}$ \\
\hline Jamacha Hills & DECO13_3JAHI006 & 32.721 & -116.960 & 0.081 & 0.174 & 0.167 & 0.064 & 0.050 & 0.019 & 2 & 11.758 \\
\hline Paradise Valley & DECO13_2PAVA001 & 32.688 & -117.053 & 0.053 & 0.217 & 0.216 & 0.088 & 0.035 & 0.016 & 2 & 11.522 \\
\hline Mother Miguel & DECO13_3MMGR010 & 32.685 & -116.973 & 0.048 & 0.184 & 0.506 & 0.058 & 0.022 & 0.011 & 0 & 11.567 \\
\hline Shinohara VP & DECO13_3SVPC007 & 32.683 & -116.990 & 0.100 & 0.158 & -0.036 & 0.060 & 0.058 & 0.021 & 1 & 10.848 \\
\hline San Miguel West & DECO13_3SMHA024 & 32.678 & -116.958 & 0.079 & 0.201 & -0.020 & 0.058 & 0.061 & 0.022 & 2 & 11.103 \\
\hline Bonita Meadows & DECO13_3ВОME009 & 32.673 & -116.999 & 0.073 & 0.173 & -0.046 & 0.089 & 0.055 & 0.019 & 1 & 11.000 \\
\hline Proctor Valley & DECO13_3PRVA013 & 32.673 & -116.927 & 0.158 & 0.183 & -0.078 & 0.069 & 0.054 & 0.014 & 3 & 10.759 \\
\hline Trimark SDNWR & DECO13_3TRIM008 & 32.668 & -116.988 & 0.031 & 0.192 & 0.231 & 0.059 & 0.050 & 0.019 & 1 & 12.303 \\
\hline PMA4 & DECO13_3PMA4005 & 32.664 & -117.011 & 0.142 & 0.181 & -0.066 & 0.058 & 0.068 & 0.021 & 0 & 11.265 \\
\hline Rancho Jamul & DECO13_3RJER015 & 32.659 & -116.862 & 0.098 & 0.250 & 0.199 & 0.055 & 0.050 & 0.018 & 0 & 13.700 \\
\hline Rice Canyon & DECO13_3PMA1002 & 32.644 & -117.016 & 0.071 & 0.164 & 0.191 & 0.077 & 0.053 & 0.017 & 3 & 12.152 \\
\hline Chula Vista & DECO13_3PMA2003 & 32.625 & -117.013 & 0.098 & 0.167 & 0.127 & 0.059 & 0.053 & 0.020 & 0 & 11.676 \\
\hline Poggi Canyon & DECO13_3РMA3004 & 32.608 & -117.025 & -0.004 & 0.245 & 0.074 & 0.111 & 0.021 & 0.011 & 1 & 11.476 \\
\hline Dennery Ranch E & DECO13_3DREA021 & 32.583 & -117.024 & 0.078 & 0.205 & 0.302 & 0.053 & 0.031 & 0.013 & 3 & 13.375 \\
\hline Lonestar & NA & 32.579 & -116.951 & 0.055 & 0.242 & 0.304 & 0.058 & 0.030 & 0.011 & 0 & 12.606 \\
\hline Otay Mesa South & DECO13_3WMCA023 & 32.566 & -117.028 & 0.091 & 0.190 & 0.282 & 0.060 & 0.035 & 0.012 & 0 & 11.759 \\
\hline
\end{tabular}


Table 2-5. Dicranostegia orcuttiana occurrence locations and summary statistics.

[SP, State Park; TJ, Tijuana]

\begin{tabular}{|c|c|c|c|c|c|c|c|c|c|c|c|}
\hline Occurrence & SDMMP ID & Latitude & Longitude & $F_{I S}$ & $\begin{array}{c}F_{I S} \\
\text { St. Err }\end{array}$ & $r$ & $\begin{array}{c}r \\
\text { St. Err }\end{array}$ & $H_{e}$ & $\begin{array}{c}H_{e} \\
\text { St. Err }\end{array}$ & $\begin{array}{l}\text { Private } \\
\text { alleles }\end{array}$ & $\begin{array}{c}\text { Sample } \\
\text { size }\end{array}$ \\
\hline Rice Canyon & COOR7_3PMA1002 & 32.644 & -117.027 & 0.133 & 0.263 & 0.266 & 0.028 & 0.122 & 0.022 & 6 & 13.417 \\
\hline Otay River & COOR7_3ORVA001 & 32.587 & -117.044 & 0.258 & 0.291 & -0.049 & 0.035 & 0.135 & 0.027 & 5 & 13.028 \\
\hline Cal Terraces & COOR7_3DREA007 & 32.584 & -117.025 & 0.161 & 0.264 & 0.020 & 0.025 & 0.142 & 0.024 & 5 & 13.672 \\
\hline Borderfield SP & COOR7_1BFSP006 & 32.541 & -117.108 & 0.082 & 0.228 & 0.361 & 0.029 & 0.091 & 0.021 & 4 & 12.885 \\
\hline TJ River & COOR7_1TRVRP008 & 32.540 & -117.100 & 0.117 & 0.194 & 0.043 & 0.028 & 0.131 & 0.020 & 12 & 12.815 \\
\hline
\end{tabular}


Table 2-6. Monardella viminea occurrence locations and summary statistics.

[Clem, Clemente; Cyn, Canyon; MCAS, Marine Corps Air Station Miramar; Syc, Sycamore; W, West]

\begin{tabular}{|c|c|c|c|c|c|c|c|c|c|c|c|}
\hline Occurrence & SDMMP ID & Latitude & Longitude & $F_{I S}$ & $\begin{array}{c}\text { FIS } \\
\text { St. Err }\end{array}$ & $r$ & $\begin{array}{c}r \\
\text { St. Err }\end{array}$ & $H_{e}$ & $\begin{array}{c}H_{e} \\
\text { St. Err } \\
\end{array}$ & $\begin{array}{l}\text { Private } \\
\text { alleles }\end{array}$ & $\begin{array}{c}\text { Sample } \\
\text { size }\end{array}$ \\
\hline Lopez Cyn & MOLIV_6LOCA004 & 32.914 & -117.174 & 0.038 & 0.058 & 0.110 & 0.100 & 0.141 & 0.024 & 0 & 6.667 \\
\hline Flanders Cyn & MOLIV_6FLCA007 & 32.900 & -117.172 & 0.088 & 0.038 & 0.021 & 0.044 & 0.169 & 0.036 & 0 & 12.038 \\
\hline W San Clem Miramar & Miramar_SCC-West & 32.850 & -117.161 & -0.007 & 0.114 & 0.137 & 0.025 & 0.176 & 0.024 & 2 & 14.358 \\
\hline San Clem 163 Miramar & Miramar_SCC- 163 & 32.851 & -117.134 & 0.071 & 0.090 & 0.064 & 0.026 & 0.153 & 0.023 & 2 & 12.433 \\
\hline San Clem Miramar & Miramar_SCC-Q, P & 32.894 & -117.064 & 0.018 & 0.073 & -0.010 & 0.026 & 0.148 & 0.022 & 0 & 12.179 \\
\hline Spring Cyn & MOLIV_4SPCA008 & 32.863 & -117.037 & 0.058 & 0.101 & 0.213 & 0.041 & 0.096 & 0.029 & 0 & 12.222 \\
\hline W Syc Cyn Miramar 1 & Miramar_WSC-A, O,N & 32.885 & -117.011 & 0.076 & 0.130 & 0.075 & 0.019 & 0.162 & 0.021 & 1 & 13.729 \\
\hline W Syc Cyn Miramar 2 & Miramar_WSC- H, G, L & 32.903 & -117.011 & 0.048 & 0.154 & 0.124 & 0.020 & 0.164 & 0.025 & 2 & 13.404 \\
\hline W Syc Cyn City & MOLIV_4WSCA003 & 32.920 & -117.001 & -0.002 & 0.135 & 0.374 & 0.036 & 0.123 & 0.038 & 0 & 11.550 \\
\hline Syc Cyn Miramar & Miramar_SC-W & 32.898 & -116.991 & 0.038 & 0.101 & 0.188 & 0.020 & 0.141 & 0.022 & 1 & 13.591 \\
\hline Syc Cyn City & MOLIV_4SYCA001 & 32.923 & -116.990 & 0.035 & 0.120 & 0.212 & 0.023 & 0.137 & 0.021 & 3 & 13.394 \\
\hline Syc Cyn County & MOLIV_4SYCA006 & 32.918 & -116.974 & 0.052 & 0.056 & 0.064 & 0.059 & 0.117 & 0.022 & 0 & 10.258 \\
\hline
\end{tabular}


Table 2-7. Summary of management ranking decision, general strategies proposed by Ottwewell and others (2016), specific compatible potential management options, and additional needed information by species.

[CA, California; CBI, Conservation Biology Institute; Cyn, Canyon; E, East; EO, element occurrence; IBD, isolation by distance; ID, identification; Mtn, Mountain; MX, Mexico; $r$, relatedness; Fis, inbreeding coefficient, SNP, single nucleotide polymorphism; SW, South West; Ter, Terraces; TNC, The Nature Conservancy]

\begin{tabular}{|c|c|c|c|c|c|c|c|}
\hline Ranking & Divergence & Diversity & $\begin{array}{l}\text { Relatedness } \\
\text { \& inbreeding }\end{array}$ & General strategies & $\begin{array}{c}\text { Compatible management } \\
\text { options }\end{array}$ & Information needs & Additional notes \\
\hline \multicolumn{8}{|c|}{ Acanthomintha ilicifolia } \\
\hline 7 or 8 & $\begin{array}{l}\text { High; sig. IBD, } \\
\text { 3-5 clusters } \\
\text { within San } \\
\text { Diego. } \\
\text { Northern and } \\
\text { eastern } \\
\text { occurrences } \\
\text { group } \\
\text { separately. } \\
\text { No ploidy } \\
\text { differences } \\
\text { detected in } \\
\text { this study; } \\
\text { mixed ploidy } \\
\text { previously } \\
\text { detected } \\
\text { (DeWoody } \\
\text { and others, } \\
\text { 2018). }\end{array}$ & $\begin{array}{l}\text { Low: Emerald } \\
\text { Pointe, Lux } \\
\text { Cyn, } \\
\text { Palomar } \\
\text { Airport, } \\
\text { Wright's } \\
\text { Field and } \\
\text { Viejas }\end{array}$ & $\begin{array}{l}r: \text { some high } \\
\text { in north } \\
\text { and east, } \\
F_{\text {is: low }}\end{array}$ & $\begin{array}{l}\text { (1) Populations have } \\
\text { historically been } \\
\text { isolated and have } \\
\text { little contemporary } \\
\text { gene flow. } \\
\text { Populations closer to } \\
\text { one another have had } \\
\text { more historical gene } \\
\text { flow than those } \\
\text { farther apart. } \\
\text { (2) Translocations } \\
\text { between populations } \\
\text { could be risky due to } \\
\text { potential outbreeding } \\
\text { depression. Assess } \\
\text { risks with further } \\
\text { research or employ } \\
\text { risk management } \\
\text { strategies, for } \\
\text { example, composite } \\
\text { provenancing. } \\
\text { (3) Investigate means to } \\
\text { potentially recover } \\
\text { diversity in situ (from } \\
\text { soil seedbank) or } \\
\text { increase recruitment } \\
\text { to boost population } \\
\text { sizes. } \\
\text { (4) Consider composite } \\
\text { provenancing } \\
\text { translocation strategy } \\
\text { to introduce new } \\
\text { diversity if } \\
\text { outbreeding risks are } \\
\text { determined to be low. }\end{array}$ & $\begin{array}{l}\text { (1) Remove weeds and } \\
\text { perform other } \\
\text { management to } \\
\text { maximize size and } \\
\text { diversity within sites } \\
\text { and replenish seed } \\
\text { banks. } \\
\text { (2) Low diversity and } \\
\text { small isolated } \\
\text { populations may need } \\
\text { more seed. } \\
\text { (3) Ploidy and outbreeding } \\
\text { impacts should be } \\
\text { further understood prior } \\
\text { to moving seed among } \\
\text { occurrences. } \\
\text { (4) After resolving } \\
\text { potential ploidy or } \\
\text { outbreeding depression } \\
\text { impacts, could } \\
\text { encourage planting for } \\
\text { stepping stone } \\
\text { connectivity (for } \\
\text { example, Palomar } \\
\text { Airport). } \\
\text { (5) Track seed } \\
\text { collection/distribution } \\
\text { and check ploidy levels } \\
\text { before restoring } \\
\text { populations. Conduct } \\
\text { long term monitoring at } \\
\text { restored sites to track } \\
\text { success. } \\
\text { (6) Coordinate with Mark } \\
\text { Dodero and Scott } \\
\text { McMillan on seasonal } \\
\end{array}$ & $\begin{array}{l}\text { (1) Conduct crosses } \\
\text { between populations } \\
\text { to evaluate offspring } \\
\text { fitness. Design } \\
\text { common garden study } \\
\text { to do crosses within } \\
\text { population, within } \\
\text { same zone/cluster (for } \\
\text { example, northern } \\
\text { zone) and across zones } \\
\text { and track genetics and } \\
\text { fitness measures. } \\
\text { Design experiment to } \\
\text { account for } \\
\text { environmental } \\
\text { gradient across the } \\
\text { species range. } \\
\text { (2) Determine seedbank } \\
\text { viability and } \\
\text { germination conditions } \\
\text { (for example, night } \\
\text { temperature and soil } \\
\text { moisture). Could be } \\
\text { important for sites } \\
\text { where plants are not } \\
\text { coming up. } \\
\text { (3) Conduct surveys of } \\
\text { potentially suitable } \\
\text { habitat to search for } \\
\text { more populations. } \\
\text { (4) Range continues } \\
\text { south in Baja CA, } \\
\text { MX, which may not be } \\
\text { impacted by } \\
\text { Brachypodium } \\
\text { distachyon weeds, like } \\
\end{array}$ & $\begin{array}{l}\text { We did not find any } \\
\text { ploidy differences } \\
\text { across occurrences } \\
\text { (5 plants per } \\
\text { occurrence were } \\
\text { tested with flow } \\
\text { cytometry). } \\
\text { Possibly mixed } \\
\text { ploidy at a few } \\
\text { sites- confirmed } \\
\text { mixed } \\
\text { diploid/tetraploids } \\
\text { at Carlsbad EO 70 } \\
\text { although for most } \\
\text { site/individuals, } \\
\text { the ploidy was } 4 x \\
\text { (DeWoody and } \\
\text { others, 2018). } \\
\text { From CBI study: } \\
\text { there are many } \\
\text { more consistently } \\
\text { small populations } \\
\text { than larger ones. }\end{array}$ \\
\hline
\end{tabular}




\begin{tabular}{|c|c|c|c|c|c|c|c|}
\hline Ranking & Divergence & Diversity & $\begin{array}{l}\text { Relatedness } \\
\text { \& inbreeding }\end{array}$ & General strategies & $\begin{array}{c}\text { Compatible management } \\
\text { options }\end{array}$ & Information needs & Additional notes \\
\hline & & & & $\begin{array}{l}\text { (5) Given IBD, source } \\
\text { from geographically } \\
\text { closer populations. }\end{array}$ & $\begin{array}{l}\text { timing and best } \\
\text { practices for } \\
\text { distributing seed. }\end{array}$ & $\begin{array}{l}\text { many other sites are. } \\
\text { Determine status of } \\
\text { Baja sites (last } \\
\text { surveyed in 1970s). } \\
\text { Could harbor } \\
\text { additional genetic } \\
\text { diversity useful for } \\
\text { future restoration in } \\
\text { San Diego. Could } \\
\text { conduct a genetic } \\
\text { survey in Baja to } \\
\text { determine structure } \\
\text { and ploidy to compare } \\
\text { with San Diego. }\end{array}$ & \\
\hline \multicolumn{8}{|c|}{ Baccharis vanessae } \\
\hline 1 & $\begin{array}{l}\text { Low; no IBD; } \\
\text { Mt Woodson, } \\
\text { Otay and } \\
\text { Escondido } \\
\text { Creek show } \\
\text { some genetic } \\
\text { differences. }\end{array}$ & $\begin{array}{l}\text { High/even } \\
\text { diversity; } \\
\text { lowest at } \\
\text { Iron Mtn. }\end{array}$ & $\begin{array}{c}r \text { : variable, } \\
F_{I S} \text { : low }\end{array}$ & $\begin{array}{l}\text { (1) Populations have } \\
\text { historically been } \\
\text { connected and } \\
\text { currently maintain } \\
\text { gene flow. } \\
\text { Translocation } \\
\text { between populations } \\
\text { is viable option to } \\
\text { boost population } \\
\text { sizes, results support } \\
\text { using material from } \\
\text { closest geographic } \\
\text { sources. } \\
\text { (2) Outbreeding } \\
\text { depression is likely to } \\
\text { be minimal. } \\
\text { (3) Manage species- } \\
\text { level ecological and } \\
\text { demographic threats } \\
\text { to maintain } \\
\text { population sizes and } \\
\text { gene flow (corridors) } \\
\text { (4) Maintain/facilitate } \\
\text { metapopulation } \\
\text { dynamics }\end{array}$ & $\begin{array}{l}\text { (1) This plant requires } \\
\text { careful ID with } \\
\text { confirmation by } \\
\text { experts. It is } \\
\text { inconspicuous. } \\
\text { (2) Surveys could detect } \\
\text { additional populations } \\
\text { in the gaps between } \\
\text { existing populations. } \\
\text { (3) Conduct reproduction } \\
\text { study to better } \\
\text { understand phenology } \\
\text { and determine seedling } \\
\text { recruitment. } \\
\text { (4) Establish an ex situ } \\
\text { population for study } \\
\text { and seed source. Collect } \\
\text { seed and cuttings of } \\
\text { known sex ratios to } \\
\text { establish ex situ } \\
\text { population. Could try } \\
\text { crosses at some point. }\end{array}$ & $\begin{array}{l}\text { (1) Are soil differences at } \\
\text { some sites correlated } \\
\text { with genetic } \\
\text { differences? } \\
\text { (2) Not much known } \\
\text { about the biology of } \\
\text { this plant- male and } \\
\text { females are separate } \\
\text { plants. } \\
\text { (3) High genetic } \\
\text { connectivity indicates } \\
\text { that this species could } \\
\text { have been more } \\
\text { widespread and there } \\
\text { could still be } \\
\text { additional unknown } \\
\text { occurrences. } \\
\text { (4) Need information on } \\
\text { the status of } \\
\text { reproduction and } \\
\text { recruitment. No } \\
\text { seedlings were } \\
\text { detected in field } \\
\text { surveys. No viable } \\
\text { seeds collected from } \\
\text { Olivenhain Dam } \\
\text { (Rancho Santa Ana }\end{array}$ & $\begin{array}{l}\text { Three sites new to } \\
\text { project. } \\
\text { Found on variety of } \\
\text { soils. Otay } \\
\text { Mountain } \\
\text { occurrences on } \\
\text { metavolcanics, Mt. } \\
\text { Woodson \& } \\
\text { Gibson Highlands } \\
\text { are granite, and the } \\
\text { rest are loamy } \\
\text { sand. }\end{array}$ \\
\hline
\end{tabular}




\begin{tabular}{|c|c|c|c|c|c|c|c|}
\hline Ranking & Divergence & Diversity & $\begin{array}{l}\text { Relatedness } \\
\text { \& inbreeding }\end{array}$ & General strategies & $\begin{array}{c}\text { Compatible management } \\
\text { options }\end{array}$ & Information needs & Additional notes \\
\hline & & & & & & $\begin{array}{l}\text { Botanical Gardens, } \\
\text { RSABG). } \\
\text { (5) RSABG has proposed } \\
\text { to grow out seed and } \\
\text { assess demographics. } \\
\text { (6) Investigate } \\
\text { phenology, appears } \\
\text { variable. }\end{array}$ & \\
\hline \multicolumn{8}{|c|}{ Chloropyron maritimum ssp. maritimum } \\
\hline 3 & $\begin{array}{l}\text { Low, no IBD; } 1 \\
\text { cluster within } \\
\text { San Diego, no } \\
\text { ploidy } \\
\text { differences }\end{array}$ & $\begin{array}{l}\text { Low: Paradise } \\
\text { Marsh, NB } \\
\text { Coronado, } \\
\text { Dog Beach, } \\
\text { Sweetwater } \\
\text { Higher: } \\
\text { Tijuana } \\
\text { Estuary } \\
\text { Regional } \\
\text { diversity } \\
\text { outside San } \\
\text { Diego is } \\
\text { lower than } \\
\text { Tijuana } \\
\text { Estuary. }\end{array}$ & $\begin{array}{l}r \text { : some } \\
\text { high, } \\
\text { FIS: low }^{\text {fow }}\end{array}$ & $\begin{array}{l}\text { (1) Populations have } \\
\text { historically been } \\
\text { connected and } \\
\text { currently maintain } \\
\text { gene flow. } \\
\text { Translocation } \\
\text { between populations } \\
\text { is viable option to } \\
\text { boost population } \\
\text { sizes. } \\
\text { (2) Outbreeding } \\
\text { depression is likely to } \\
\text { be minimal. } \\
\text { (3) Could manage to } \\
\text { increase recruitment } \\
\text { and facilitate } \\
\text { pollen/seed } \\
\text { immigration or } \\
\text { actively translocate } \\
\text { individuals to } \\
\text { increase population } \\
\text { size. } \\
\text { (4) Investigate means to } \\
\text { recover diversity in } \\
\text { situ. }\end{array}$ & $\begin{array}{l}\text { (1) In San Diego Co. use } \\
\text { seed from diverse } \\
\text { Tijuana Estuary for } \\
\text { population } \\
\text { enhancement and } \\
\text { establishment at other } \\
\text { sites (Sweetwater } \\
\text { Estuary, NB Coronado) } \\
\text { (2) NB Coronado small } \\
\text { with trails nearby and } \\
\text { could be vulnerable to } \\
\text { extirpation. Native } \\
\text { species diversity } \\
\text { appears lower at this } \\
\text { site. Could fence site } \\
\text { and add seed. } \\
\text { (3) Sweetwater Marsh has } \\
\text { high impact (homeless } \\
\text { encampment and one } \\
\text { entry/exit route). Could } \\
\text { restore with seeds. } \\
\text { Paradise Marsh and } \\
\text { Sweetwater Marsh } \\
\text { could be threatened by } \\
\text { sea level rise. } \\
\text { (4) Dog Beach is impacted } \\
\text { by seed herbivores } \\
\text { (moths), and Limonium } \\
\text { sp. Could conduct weed } \\
\text { management. May be } \\
\text { an outplanted site. } \\
\text { (5) Conduct multi-year } \\
\text { seed collections for } \\
\end{array}$ & $\begin{array}{l}\text { (1) Follow up results of - } \\
\text { 1990s Sweetwater } \\
\text { Marsh restoration } \\
\text { project and } \\
\text { monitoring. } \\
\text { (2) Host plants unknown, } \\
\text { could be native and } \\
\text { (or) non-native. } \\
\text { (3) Possible taxonomic } \\
\text { issues range wide } \\
\text { (observed color and } \\
\text { growth form } \\
\text { differences, high } \\
\text { genetic distinctiveness } \\
\text { of regional } \\
\text { populations) } \\
\text { (4) Conduct common } \\
\text { garden experiments to } \\
\text { look at differences } \\
\text { range-wide prior to } \\
\text { movement. } \\
\text { (5) For outplanting, need } \\
\text { to understand habitat } \\
\text { requirements such as } \\
\text { hydrological } \\
\text { conditions. }\end{array}$ & $\begin{array}{l}\text { High genetic } \\
\text { distinctiveness } \\
\text { among regional } \\
\text { populations. } \\
\text { Results indicate } \\
\text { not to move plants } \\
\text { or seeds among } \\
\text { regions or to bring } \\
\text { plants or seeds } \\
\text { from other parts of } \\
\text { the range into San } \\
\text { Diego County. }\end{array}$ \\
\hline
\end{tabular}




\begin{tabular}{|c|c|c|c|c|c|c|c|}
\hline Ranking & Divergence & Diversity & $\begin{array}{l}\text { Relatedness } \\
\text { \& inbreeding }\end{array}$ & General strategies & $\begin{array}{c}\text { Compatible management } \\
\text { options }\end{array}$ & Information needs & Additional notes \\
\hline & & & & & $\begin{array}{l}\text { conservation banking } \\
\text { and as seed sources for } \\
\text { management actions. } \\
\text { (6) Revisit and search for } \\
\text { Borderfields } \\
\text { occurrence. } \\
\text { (7) Identify possible new } \\
\text { climate refugia sites in } \\
\text { San Diego } \\
\text { (Penasquitos, Mission } \\
\text { Bay (restoration at } \\
\text { Campland), Bataquitos } \\
\text { Lagoon, Tijuana } \\
\text { Estuary (east/upland of } \\
\text { current sites). }\end{array}$ & & \\
\hline \multicolumn{8}{|c|}{ Deinandra conjugens } \\
\hline 1 & $\begin{array}{l}\text { Low, no IBD; } 1 \\
\text { regional } \\
\text { cluster }\end{array}$ & $\begin{array}{l}\text { High/even } \\
\text { diversity }\end{array}$ & $\begin{array}{l}r: \text { mostly } \\
\text { low, } \\
F_{\text {IS: low }}\end{array}$ & $\begin{array}{l}\text { (1) Populations have } \\
\text { historically been } \\
\text { connected and } \\
\text { currently maintain } \\
\text { gene flow. } \\
\text { Translocation } \\
\text { between populations } \\
\text { is viable option to } \\
\text { boost population } \\
\text { sizes. } \\
\text { (2) Outbreeding } \\
\text { depression is likely to } \\
\text { be minimal. } \\
\text { (3) Manage species- } \\
\text { level ecological and } \\
\text { demographic threats } \\
\text { to maintain } \\
\text { population sizes and } \\
\text { gene flow ( corridors) } \\
\text { (4) Maintain/facilitate } \\
\text { metapopulation } \\
\text { dynamics. }\end{array}$ & $\begin{array}{l}\text { (1) Continue to monitor } \\
\text { and conduct routine } \\
\text { management. } \\
\text { (2) Retain existing } \\
\text { diversity and } \\
\text { connectivity (this could } \\
\text { eventually decline } \\
\text { owing to habitat loss). } \\
\text { Restore within sites and } \\
\text { manage invasives. } \\
\text { (3) Manage or restore } \\
\text { stepping stone sites } \\
\text { among larger } \\
\text { occurrences for gene } \\
\text { flow. } \\
\text { (4) Large occurrence at } \\
\text { Jamacha Road and Hwy } \\
\text { 94-needs SDMMP } \\
\text { identification number- } \\
\text { biggest site last season. } \\
\text { (5) Create a key to } \\
\text { differentiate } D \text {. } \\
\text { paniculata/D. } \\
\text { conjugens-these can } \\
\text { co-occur. }\end{array}$ & $\begin{array}{l}\text { (1) The extent of Baja } \\
\text { CA, MX distribution } \\
\text { and status is unknown. } \\
\text { (2) Collect genetic } \\
\text { samples through Baja } \\
\text { CA, MX. range to } \\
\text { compare with San } \\
\text { Diego diversity. }\end{array}$ & $\begin{array}{l}\text { Observations indicate } \\
\text { new plants will } \\
\text { grow after invasive } \\
\text { species removal } \\
\text { management, } \\
\text { indicate viable } \\
\text { large seed bank. }\end{array}$ \\
\hline
\end{tabular}




\begin{tabular}{|c|c|c|c|c|c|c|c|}
\hline Ranking & Divergence & Diversity & $\begin{array}{l}\text { Relatedness } \\
\text { \& inbreeding }\end{array}$ & General strategies & $\begin{array}{c}\text { Compatible management } \\
\text { options }\end{array}$ & Information needs & Additional notes \\
\hline & & & & & $\begin{array}{l}\text { (6) Collect seeds across } \\
\text { multiple years to } \\
\text { capture diversity in seed } \\
\text { bank. }\end{array}$ & & \\
\hline \multicolumn{8}{|c|}{ Dicranostegia orcuttiana } \\
\hline 1 & $\begin{array}{l}\text { Low, no IBD; } 1 \\
\text { cluster within } \\
\text { San Diego; no } \\
\text { ploidy } \\
\text { differences }\end{array}$ & $\begin{array}{l}\text { Mostly } \\
\text { high/even. } \\
\text { Lowest at } \\
\text { Borderfield } \\
\text { • }\end{array}$ & $\begin{array}{l}r: \text { low, } \\
\text { FIS: low }\end{array}$ & $\begin{array}{l}\text { (1) Populations have } \\
\text { historically been } \\
\text { connected and } \\
\text { currently maintain } \\
\text { gene flow. } \\
\text { Translocation } \\
\text { between populations } \\
\text { is viable option to } \\
\text { boost population } \\
\text { sizes, consider using } \\
\text { closest geographic } \\
\text { sources. } \\
\text { (2) Outbreeding } \\
\text { depression is likely to } \\
\text { be minimal. } \\
\text { (3) Manage species- } \\
\text { level ecological and } \\
\text { demographic threats } \\
\text { to maintain } \\
\text { population sizes and } \\
\text { gene flow (corridors). } \\
\text { (4) Maintain/facilitate } \\
\text { metapopulation } \\
\text { dynamics. }\end{array}$ & $\begin{array}{l}\text { (1) Monitor known } \\
\text { occurrences } \\
\text { (2) Survey for additional } \\
\text { occurrences. } \\
\text { (3) Consider moving seeds } \\
\text { or plants to retain } \\
\text { diversity and gene flow. } \\
\text { (4) Awareness and } \\
\text { identification training } \\
\text { for land managers. }\end{array}$ & $\begin{array}{l}\text { (1) Host species are } \\
\text { unknown. } \\
\text { (2) Full distribution of } \\
\text { occurrences in So. CA } \\
\text { is unknown; could use } \\
\text { additional surveys and } \\
\text { reporting occurrences. } \\
\text { (3) Determine if seeding } \\
\text { is occurring. } \\
\text { (4) Condition of soil } \\
\text { seedbank and seed } \\
\text { viability are unknown. } \\
\text { (5) Majority of the } \\
\text { species range is in } \\
\text { Baja CA, MX. Genetic } \\
\text { diversity and structure } \\
\text { in Baja could be } \\
\text { investigated to provide } \\
\text { comparison to San } \\
\text { Diego. }\end{array}$ & $\begin{array}{l}\text { This project found } 4 \\
\text { new occurrences } \\
\text { within the MSPA, } \\
\text { doubling the } \\
\text { known } \\
\text { distribution. } \\
\text { San Diego } \\
\text { occurrences are at } \\
\text { the northern range } \\
\text { edge of species } \\
\text { distribution, } \\
\text { consistent with } \\
\text { genetic patterns. } \\
\text { Borderfield } \\
\text { occurrence habitat } \\
\text { differs from other } \\
\text { occurrences, flat } \\
\text { area around a } \\
\text { pond. Seed may } \\
\text { have washed down } \\
\text { from Spooner } \\
\text { Mesa population. } \\
\text { In Baja CA, this } \\
\text { species occurs on } \\
\text { vernal lake shores. }\end{array}$ \\
\hline \multicolumn{8}{|c|}{ Monardella viminea } \\
\hline 1 & $\begin{array}{l}\text { Low; } 1 \text { regional } \\
\text { cluster; } \\
\text { significant } \\
\text { IBD; no } \\
\text { ploidy } \\
\text { differences }\end{array}$ & $\begin{array}{l}\text { Relatively } \\
\text { high/even } \\
\text { diversity. } \\
\text { Lowest at } \\
\text { Spring } \\
\text { Cyn. } \\
\text { Slightly } \\
\text { higher } \\
\text { diversity } \\
\text { than other }\end{array}$ & $\begin{array}{c}r: \text { low, } \\
\text { FIS: low }\end{array}$ & $\begin{array}{l}\text { (1) Populations have } \\
\text { historically been } \\
\text { connected and } \\
\text { currently maintain } \\
\text { gene flow. } \\
\text { Translocation } \\
\text { between populations } \\
\text { is viable option to } \\
\text { boost population } \\
\text { sizes. }\end{array}$ & $\begin{array}{l}\text { 1) Recruitment could be } \\
\text { low. Establish ex situ } \\
\text { populations. } \\
\text { (2) Survey at different } \\
\text { times to observe } \\
\text { seedlings. } \\
\text { (3) Tag individual plants } \\
\text { to survey through time. } \\
\text { (4) Standardize methods } \\
\text { for counting clumps }\end{array}$ & $\begin{array}{l}\text { 1) Investigate apparent } \\
\text { hydrology impacts to } \\
\text { growth and } \\
\text { recruitment. Possibly } \\
\text { related to depth of } \\
\text { water table. } \\
\text { (2) Determine what } \\
\text { habitat improvements } \\
\text { help survival and } \\
\text { growth. }\end{array}$ & \\
\hline
\end{tabular}




\begin{tabular}{|c|c|c|c|c|c|c|c|}
\hline Ranking & Divergence & Diversity & $\begin{array}{l}\text { Relatedness } \\
\text { \& inbreeding }\end{array}$ & General strategies & $\begin{array}{c}\text { Compatible management } \\
\text { options }\end{array}$ & Information needs & Additional notes \\
\hline & & $\begin{array}{l}\text { surveyed } \\
\text { species. }\end{array}$ & & $\begin{array}{l}\text { (2) Outbreeding } \\
\text { depression is likely to } \\
\text { be minimal. } \\
\text { (3) Manage species- } \\
\text { level ecological and } \\
\text { demographic threats } \\
\text { to maintain } \\
\text { population sizes and } \\
\text { gene flow ( corridors) } \\
\text { (4) Maintain/facilitate } \\
\text { metapopulation } \\
\text { dynamics } \\
\text { (5) Given IBD, best to } \\
\text { source from } \\
\text { geographically closer } \\
\text { populations. }\end{array}$ & $\begin{array}{l}\text { with partners for IMG } \\
\text { protocol. } \\
\text { (5) Conduct studies on } \\
\text { hydrology, site specific } \\
\text { habitat requirements, } \\
\text { and recruitment. } \\
\text { Identify pollinators. }\end{array}$ & $\begin{array}{l}\text { (3) Determine effects of } \\
\text { drought on } \\
\text { survivorship and } \\
\text { recruitment. } \\
\text { (4) Determine timing of } \\
\text { seed germination. } \\
\text { (5) Ex situ: test initial } \\
\text { seed viability, growth } \\
\text { experiments, then } \\
\text { establish ex situ } \\
\text { population. Do } \\
\text { baseline germination } \\
\text { trial and transplant. }\end{array}$ & \\
\hline
\end{tabular}


Publishing support provided by the U.S. Geological Survey Science Publishing Network, Sacramento Publishing Service Center

For more information concerning the research in this report, contact the Director, Western Ecological Research Center

U.S. Geological Survey

3020 State University Drive East

Sacramento, California 95819

https://www.usgs.gov/centers/werc 


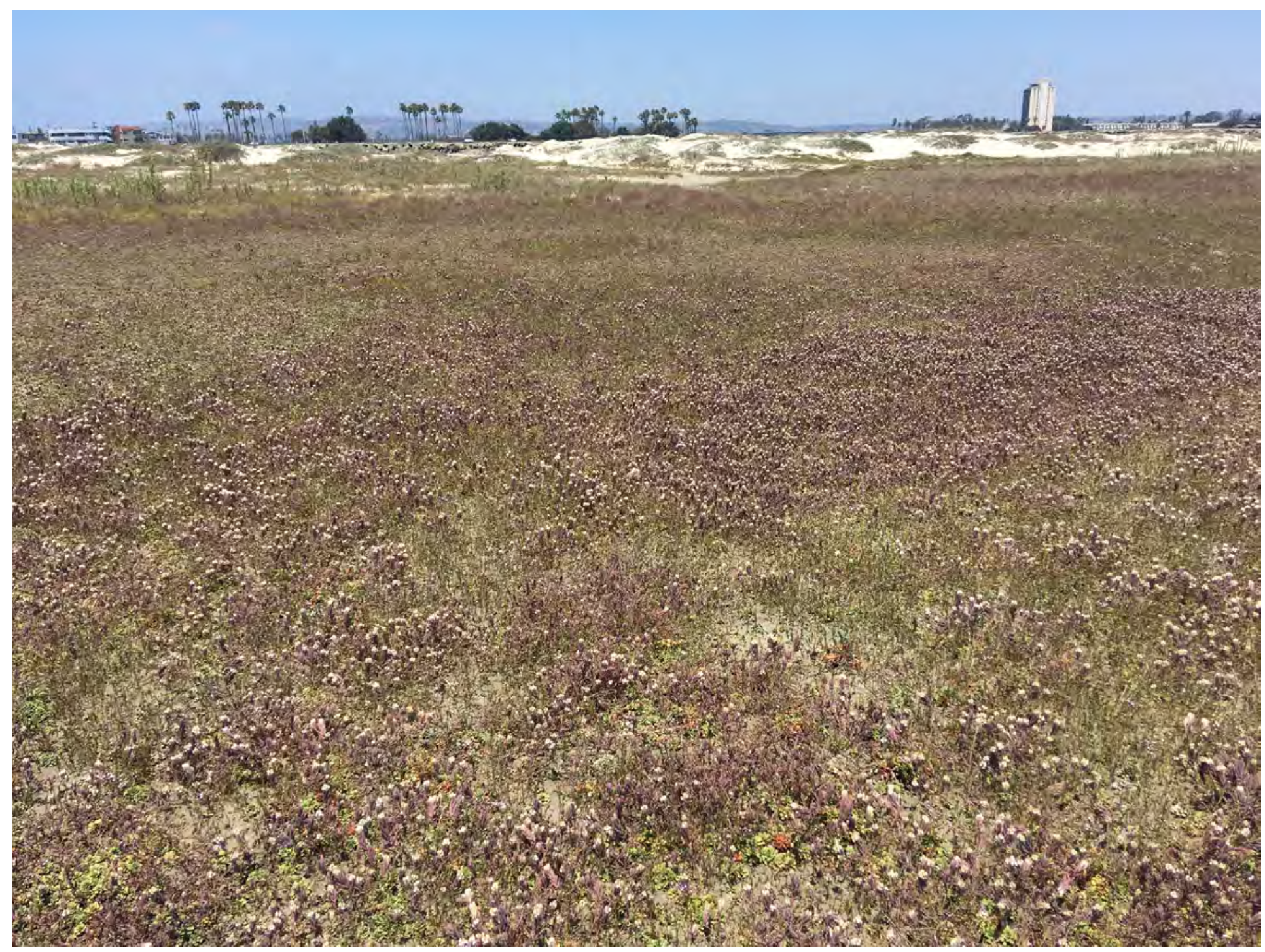

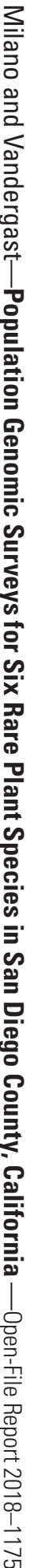

